UNIVERSIDADE DE BRASÍLIA- UnB

INSTITUTO DE CIÊNCIAS HUMANAS - IH

DEPARTAMENTO DE GEOGRAFIA - GEA

PROGRAMA DE PÓS-GRADUAÇÃO EM GEOGRAFIA - POSGEA

\title{
Gestão Socioambiental de Territórios Protegidos em Sobreposição na Amazônia Brasileira
}

\author{
Muryel Moraes Arantes
}

Orientadora: Profa.Dra. Glória Maria Vargas Lopez de Mesa

Dissertação de Mestrado

Brasília - DF, Junho de 2016. 


\section{Muryel Moraes Arantes}

\section{Gestão Socioambiental de Territórios Protegidos em Sobreposição na Amazônia Brasileira}

Dissertação de mestrado apresentada ao Programa de Pós-Graduação em Geografia do Instituto de Ciências Humanas da Universidade de Brasília, como requisito para a obtenção do título de mestra em Geografia. Área de concentração: Gestão ambiental e territorial.

Linha de pesquisa: Produção do Espaço Urbano, Rural e Regional.

Orientadora: Profa. Dra. Glória Maria Vargas Lopez de Mesa 


\section{Muryel Moraes Arantes}

\section{Gestão Socioambiental de Territórios Protegidos em Sobreposição na Amazônia Brasileira}

Esta dissertação foi julgada adequada para obtenção do título de Mestra em Geografia e aprovada em sua forma final pela orientadora e pela banca examinadora.

Orientadora:

Profa. Dra. Glória Maria Vargas Lopez de Mesa - Universidade de Brasília (UnB) Doutora pela Universidade de São Paulo - São Paulo, Brasil

Banca Examinadora

Prof. Dr. Neio Lucio de Oliveira Campos - Universidade de Brasília (UnB)

Doutor pela Universidade Federal do Rio de Janeiro - Rio de Janeiro, Brasil

Profa. Dra. Sandra de Fátima Oliveira - Universidade Federal de Goiás (UFG)

Doutora pela Universidade de São Paulo - São Paulo, Brasil

Coordenador do PPGEA:

Prof.Dr. Osmar Abílio de Carvalho Júnior.

Brasília, junho de 2016. 
ARANTES, MURYEL MORAES

Gestão Socioambiental de Territórios Protegidos em Sobreposição na Amazônia Brasileira, 140 p., (UnB - GEA, Mestre em Gestão Ambiental e Territorial, 2016).

Dissertação de Mestrado - Universidade de Brasília - Departamento de Geografia

1. Território Usado

2. Territórios Protegidos em Sobreposição

3. Políticas Públicas

4. Gestão Socioambiental

I. UnB - GEA II. Gestão Socioambiental de Territórios Protegidos em Sobreposição na Amazônia Brasileira

É concedida à Universidade de Brasília permissão para reproduzir cópias desta dissertação e emprestar ou vender tais cópias somente para propósitos acadêmicos e científicos. $\mathrm{O}$ autor reserva outros direitos de publicação e nenhuma parte desta dissertação de mestrado pode ser reproduzida sem a autorização por escrito do autor. 
Aos povos da Amazônia e seus planos de vida. 


\section{AGRADECIMENTOS}

Este trabalho resulta de uma construção conjunta. Afirmo isso porque tive a felicidade de contar com contribuições de amigas e amigos de diversas áreas. Desde Antropologia, História, Jornalismo, Geografia, Biologia, Gestão Ambiental, Direito até Artes, pude contar com contribuições diretas e indiretas ao trabalho. Por meio de diálogos, reflexões, indicações, questionamentos e todo tipo de interação que pude promover, consegui trazer um pouco de cada saber para o resultado final da pesquisa. Por isso garanto-lhes aqui os devidos créditos e a gratidão por contribuírem com uma aproximação da multidisciplinaridade.

Compartilhar este projeto, em todas as etapas, com tantas pessoas queridas foi gratificante. Posso dizer que escrevi este trabalho entre o Cerrado e a Amazônia, nas melhores companhias. Nada faria uma geógrafa mais feliz. Me sinto grata pela oportunidade.

Agradeço à minha mãe Divina e ao seu companheiro Ramón pelo apoio incondicional na busca dos meus objetivos. Vocês são parte das minhas conquistas, principalmente no desafio que tem sido dar continuidade aos estudos. À minha irmã Lais pela confiança no meu trabalho.

Ao João Victor pelo amor dedicado, por trazer leveza e companherismo nos momentos mais difíceis e nos mais felizes também. Sobretudo pelos finais de semana na biblioteca.

À minha orientadora, Profa. Dra. Glória, por estar presente indicando os melhores caminhos para o desenvolvimento da pesquisa. Sempre com muita serenidade e respeito às minhas escolhas.

Ao Prof. Dr. Neio pelo apoio na construção metodológica e na fase de qualificação do trabalho. Suas contribuições foram preciosas. Ao Prof. Dr. Everaldo pelo trabalho na disciplina Teoria e Métodos em Geografia, que se tornou um espaço de diálogo e aprendizado que ajudou muito na pesquisa.

À Profa. Dra. Sandra pela contribuição à minha formação que compõe uma parte importante da minha visão de mundo.

Aos servidores da secretaria de pós-graduação Agnelo, Jorge e Jorginho pela gentileza e colaboração nas demandas com o sistema.

Às queridas amigas Flora, Marianna, Lorena, Bianca e Débora. Aos queridos amigos Rodrigo, Mauro, Ramón e Felipe. Meu amor por vocês está em tudo que eu faço. Agradeço por segurarem minhas ondas e por serem tão lindos nessa cidade linda. 
Às companheiras Ana Carolina e Andréa pelo cotidiano leve e carinhoso e pelas contribuições na preparação da qualificação e defesa, pelos diálogos sobre política e Amazônia.

À Iane Maria e seu filho Igor por me lembrarem que sempre há tempo para uma tarde tranquila no Lago Oeste. Esses momentos de descanso foram importantes para recarregar as energias e prosseguir com a pesquisa. Muito amor ter vocês na vida.

Às todas as pessoas que integram a Equipe de Conservação da Amazônia por compartilharem suas experiências e por serem compreensivas com o tempo que dediquei à pesquisa. Ao Wesley e ao Vasco pela oportunidade de fazer parte deste trabalho que me proporcionou vivenciar o bioma Amazônia, conhecendo seu povo, suas histórias e projetos. Sou grata pelas frentes que impulsionam e por acreditarem no potencial das pessoas.

À querida Luíza pelo apoio e por ser uma interlocutora generosa. Agradeço pelos diálogos nos quais encontrei firmeza e boas perspectivas sobre Direito e Políticas Públicas na esfera socioambiental. À Meline, geógrafa brasiliense, por estar sempre colaborando e positivando em todas as fases da pesquisa. Sobretudo por me receber tão bem compartilhando comigo seus saberes e experiências.

À Stephanie pela excelente companhia nos momentos de escrita e trabalho em campo.

Aos biólogos da Assossiação de Defesa Etnoambiental - Kanindé, Israel e Alexander, pela ajuda na seleção dos indicadores.

Ao povo Jiahui por me permitirem pesquisar em seu território. À Apij pela autorização de uso dos dados.

À Leila Mattos, chefe da Flona de Humaitá, pela colaboração com a pesquisa facilitando o acesso aos dados da UC. À equipe responsável pelos Planos de Manejo da região Inteflúvio Purus-Madeira pela contribuição com esta pesquisa.

À Lilian por estar comigo nesta jornada.

À Vanessa pela pelas conversas inspiradoras e pela revisão do texto. Estendo esse agradecimento ao seu companheiro José que muito contribuiu no referencial teórico e na reflexão acerca da questão indígena no Brasil. 


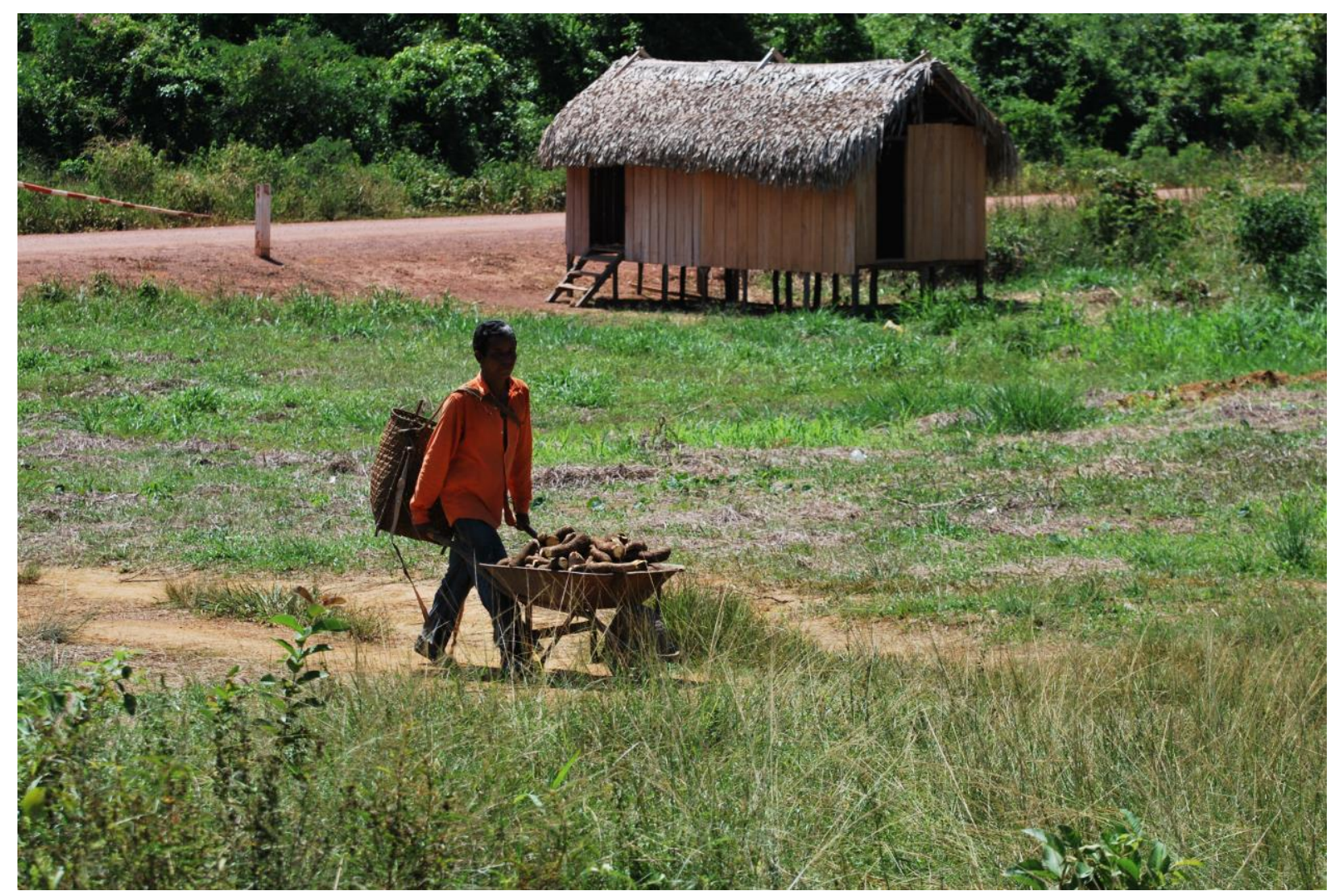

"As monoculturas da mente fazem a diversidade desaparecer da percepção e, consequentemente do mundo" (SHIVA, 2002). 


\section{RESUMO}

Dentre as responsabilidades atribuidas ao Estado pela Constituição Federal de 1988, relacionadas a questão ambiental e indígena, a criação, demarcação e gestão de Unidades de Conservação e Terras Indígenas são fundamentais. Nesse sentido, o Sistema Nacional de Unidades de Conservação e a Política Nacional de Gestão Ambiental e Territorial de Terras Indígenas são as políticas que determinam a forma com a qual o Estado vai lidar com as referidas questões e os tipos de interação da sociedade nesses espaços territoriais protegidos.Tais políticas integram um sistema de políticas públicas setoriais, isso significa que são elaboradas e implementadas em setores diferentes da agenda governamental. $\mathrm{O}$ resultado das ações dessas políticas compõe um cenário de 462 Terras Indígenas e 320 UCs da esfera federal. No bioma Amazônia estão as mais representativas em termos de tamanho e diversidade. Por consequência, os casos de sobreposição são mais expressivos neste bioma, 68\% dos casos do Brasil. Com o objetivo de analisar a gestão de UCs sustentáveis e TIs em situação de sobreposição no bioma Amazônia esta pesquisa qualitativa foi realizada com os aportes do estudo de caso. Neste, a TI Jiahui e a Floresta Nacional de Humaitá - que se encontram sobrepostas - são abordadas como Territórios Protegidos. A abordagem territorial é realizada com base nos conceitos de Território Usado e Territorialidade. A perspectiva socioambiental adotada tem o fito de contemplar as dimensões política e ambiental desses territórios. A problemática investigada consiste no fato de que os usos que fazem parte do sentido conservacionista desses territórios estão submetidos, no contexto da gestão pública, a políticas de setores diferentes, elaboradas em implementadas em espaços distintos, este é o cerne da problemática. $\mathrm{O}$ estudo de tal questão contemplou a escala nacional, por meio da análise dos objetivos e diretrizes de tais políticas, e a escala local, pela dinâmica territorial denominada transformações territoriais. Observou-se que, em tese, as políticas são complementares e que as metodologias dos instrumentos de gestão podem dar suporte a integração que representaria a dinâmica territorial. No entanto, os mecanismos de gestão estatal, ou seja, os meios de implementação não funcionam de forma complementar, o que representa um risco para a conservação socioambiental dos Territórios Protegidos em Sobreposição na Amazônia Brasileira.

Palavras-Chave: Território Usado, Territórios Protegidos em Sobreposição, Políticas Públicas, Gestão Socioambiental 


\begin{abstract}
Among the State responsibilities with environmental and indigenous issues, established by the 1988 Federal Constitution, the creation, demarcation and management of IL and Conservation Units are fundamental. The National System of Conservation Units (Sistema Nacional de Unidades de Conservação - SNUC) and the National Policy on Environmental and Territorial Management of Indigenous Lands (Política Nacional de Gestão Ambiental e Territorial de Terras Indígenas - PNGATI) are policies that determine how the State deals with these themes, and the type of social interaction that arouse in those protected territories. These policies integrate a system of sectorial public policies elaborated and implemented in different sectors and under different governmental agendas. The result of those policies composes a scenario of 462 Indigenous Lands and 320 Conservation Units under federal management. The Amazon biome hosts the most representative areas in terms of size and diversity. As a consequence, cases of superposition between Indigenous Lands and Conservation Units are expressive, corresponding to $68 \%$ of the Brazilian cases. Aiming to analyze Conservation Units and Indigenous Lands management in superposition conditions, this qualitative research were conducted based on the Indigenous Lands Jiahui e a National Forest of Humaitá Conservation Units case. These areas are approached as protected territories, based in the concepts of Used Territories and Territoriality. The socioenvironmental perspective adopted considers the political and environmental dimensions of those territories. This investigation focus on the conservationist usage of the territory, that is elaborated and implemented by different sectorial policies and in different venues. The study considered two scales of analysis. At the national scale it includes the analysis of policies objectives and guidelines. At the local scale it includes the analysis of territorial dynamics, or territorial transformations. As a result, it was observed that policies are complementary in terms of guidelines and objectives, however they are not complementary in terms of implementation. The decoupling of policies implementation represents a risk to the conservation of Superposed Protected Territories in the Brazilian Amazon.
\end{abstract}

Key-words: Used Territory, Territoriality, Superposed Protected Territories, Public Policies, Socioenvironmental Management 


\section{LISTA DE ILUSTRAÇÕES}

Figura 1 - Sobreposições entre territórios protegidos no Brasil

Figura 2- Fases e possibilidades do desenvolvimento da pesquisa ................................................... 16

Figura 3 - Mapa de localização da Terra Indígena Jiahui e da Flona de Humaitá.................................. 20

Figura 4 - Mapa do Corredor Etnoambiental Tupi-Kagawahiba, Fonte: ECAM….............................. 21

Figura 5 - Processo histórico e espacial de formação dos territórios protegidos ................................... 28

Figura 6 - Linha do tempo (reduzida) - Eventos ambientalistas e as políticas públicas ambientais no

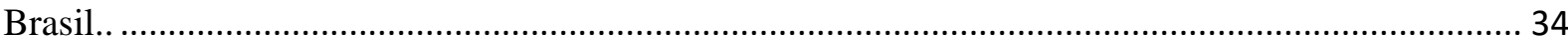

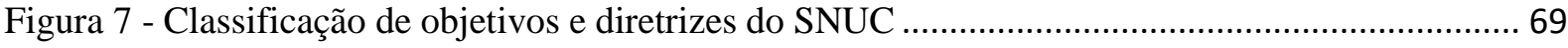

Figura 8 - Classificação dos objetivos e diretrizes da PNGATI.......................................................... 70

Figura 9 - Oficina de elaboração do PGTA Jiahui. Fonte: APIJ, 2014 …............................................ 84

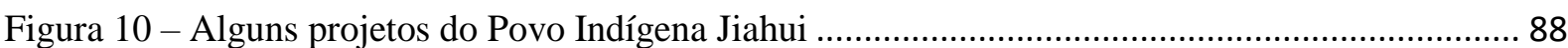

Figura 11 - Oficina de elaboração do Etnozoneamento da TI Jiahui. Fonte: APIJ,2011 .................... 91

Figura 12 - Atividade de revisão do Etnozoneamento. TI Jiahui, aldeia Ju’i. Fonte: APIJ, 2014 ........ 91

Figura 13 - Mapa do Etnozoneamento da TI Jiahui.......................................................................... 93

Figura 14 - Mapa de Localização da região do Interflúvio Purus-Madeira ........................................... 96

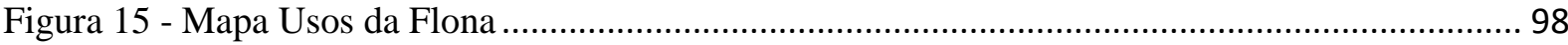

Figura 16 - Mapa Usos da Flona de Humaitá - atividades ................................................................. 99

Figura 17 - Mapa Usos da Flona de Humaita - Extrativismo e MCF................................................... 100

Figura 18 - Mapa com imagem da cobertura vegetal dos territórios protegidos .................................. 105

Figura 19 - Mapa de usos na área de fronteira entre TI e Flona........................................................ 119 


\section{LISTA DE TABELAS}

Tabela 1 - Lista dos Territórios Protegidos em Sobreposições da Amazônia Brasileira..

Tabela 2 - Registros da questão indígena nas constituições brasileiras. 38

Tabela 3 - Temas norteadores das diretrizes da PNGATI. 55

Tabela 4 - Áreas Prioritárias para os Objetivos Específicos da PNGATI. 55

Tabela 5 - Objetivos do SNUC 58

Tabela 6 - Diretrizes do SNUC 59

Tabela 7 - Categorias de UCs 60

Tabela 8 - Trajetória dos projetos de gestão anteriores à PNGATI. Fonte: MACHADO, 2014. 67

Tabela 9 - Indicadores Socioambientais dos territórios protegidos. 75

Tabela 10 - Informações sobre as zonas do Etnozoneamento 94

Tabela 11 - Análise dos Indicadores 


\section{LISTA DE ABREVIATURAS E SIGLAS}

APA - Área de Proteção Ambiental

APIJ - Assossiação do Povo Indígena Jiahui

ARPA - Programa de Áreas Protegidas da Amazônia

CDS - Comissão de Desenvolvimento Sustentável

CONAMA - Conselho Nacional do Meio Ambiente

ECAM - Equipe de Conservação da Amazônia

FLONA - Floresta Nacional

FUNAI - Fundação Nacional do Índio

GEF - Global Environment Facility

ISA - Instituto Socioambiental

MMA - Ministério do Meio Ambiente

OIT - Organização Internacional do Trabalho

ONG - Organização Não Governamental

ONU - Organização das Nações Unidas

PGTA - Plano de Gestão Territorial e Ambiental

PNGATI - Política Nacional de Gestão Ambiental e Territorial de Terras Indígenas

PNMA - Política Nacional de Meio Ambiente

PNUMA - Programa das Nações Unidas para o Meio Ambiente

PPA - Plano Plurianual

PPBio - Programa de Pesquisa em Biodiversidade

RDS - Reserva de Desenvolvimento Sustentável

RESEX - Reserva Extrativista

SEMA - Secretaria de Meio Ambiente

SISNAMA - Sistema Nacional do Meio Ambiente

SNUC - Sistema Nacional de Unidades de Conservação

SPI - Serviço de Proteção aos índios

TI - Terra Indígena

UC - Unidade de Conservação 


\begin{tabular}{|c|c|}
\hline & SUMARIO \\
\hline TRO & DDUÇÃ̃...... \\
\hline RESS & SUPOSTOS DA PESQUISA ................. \\
\hline a) & OBJETO DE ESTUDO.. \\
\hline b) & PESQUISA BIBLIOGRÁFICA - CONCEITO DE TERRITÓRIO........... \\
\hline c) & DEFINIÇÃO DO PROBLEMA ... \\
\hline d) & HIPÓTESE DE TRABALHO.. \\
\hline e) & METODOLOGIA .. \\
\hline i) & Passos metodológicos... \\
\hline f) & 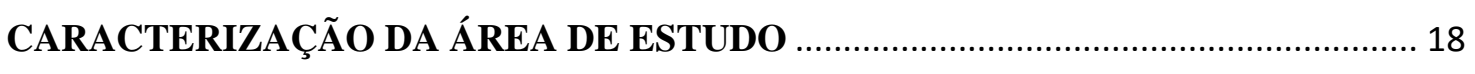 \\
\hline i) & As sobreposições da Amazônia - conforme recorte da pesquisa ..... \\
\hline i) & Contexto sócioespacial da TI Jiahui.......... \\
\hline i) & 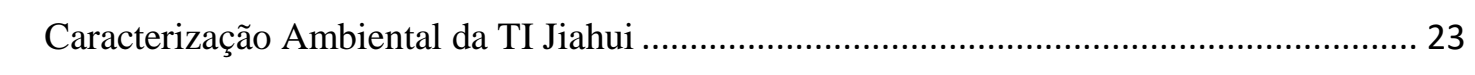 \\
\hline i) & e Estruturas \\
\hline
\end{tabular}

CAPÍTULO I - CONCEITOS FUNDAMENTAIS, RECORTES CONCEITUAL E TEMÁTICO26

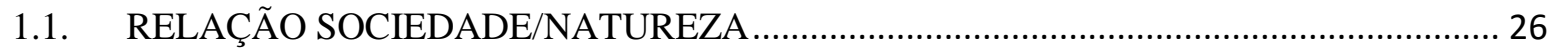

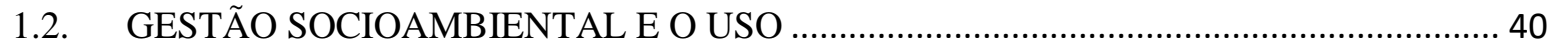

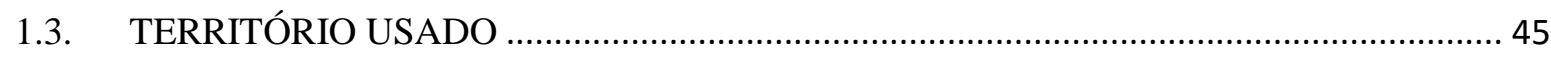

CAPÍTULO II - AS POLÍTICAS PÚBLICAS E OS INDICADORES DE TRANSFORMAÇÕES TERRITORIAIS: UMA PROPOSTA DE LEITURA ESPACIAL ................................................50

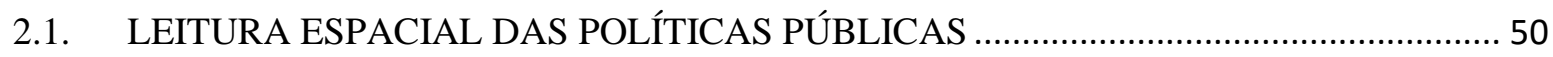

2.2. PANORAMA GERAL DO SISTEMA NACIONAL DE UNIDADES DE CONSERVAÇÃO (SNUC) E DA POLÍTICA NACIONAL DE GESTÃO TERRITORIAL E AMBIENTAL DE TERRAS INDÍGENAS (PNGATI) NO BRASIL............................................. 53

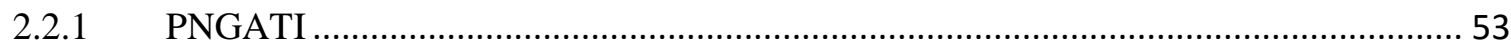

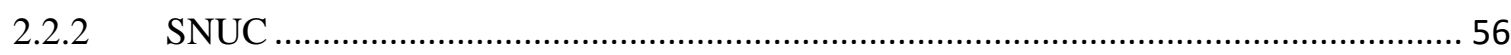

2.2.3. Concepções de preservação e conservação no SNUC e na PNGATI ...................... 61

2.2.4. Atitude do Estado frente a essas políticas ambiental e indigenista.......................... 63

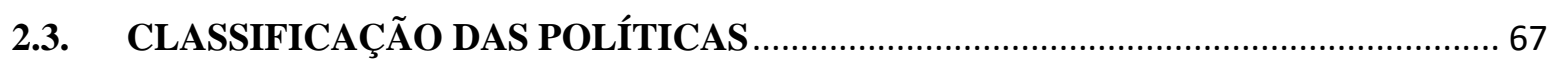

2.4. INDICADORES SOCIOAMBIENTAIS - TRANSFORMAÇÕES TERRITORIAIS ......... 71

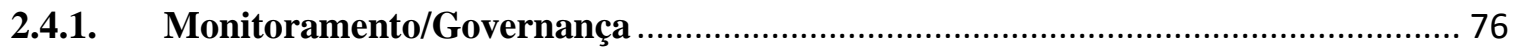


2.4.1.1. PPBIO

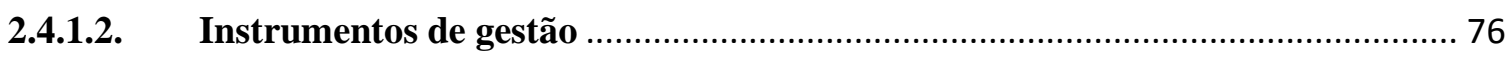

2.4.1.3. Projetos e iniciativas de gestão integrada e compartilhada ................................. 77

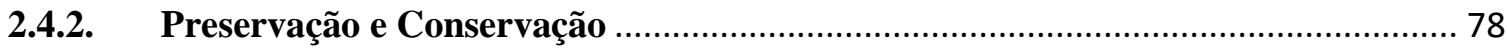

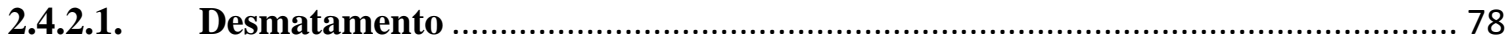

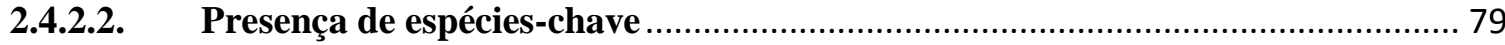

2.4.2.3. Acordos de uso nas áreas de sobreposiçãa …………………………................ 80

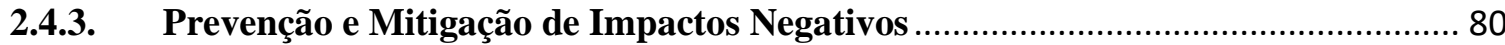

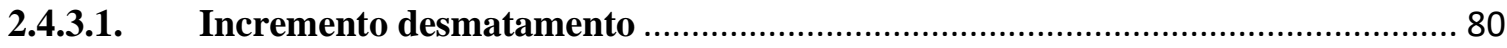

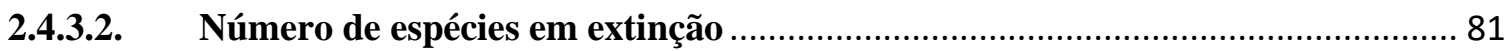

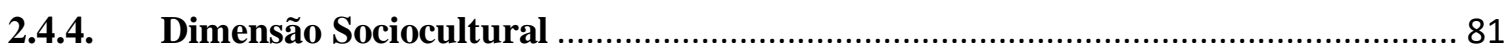

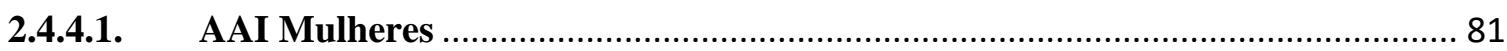

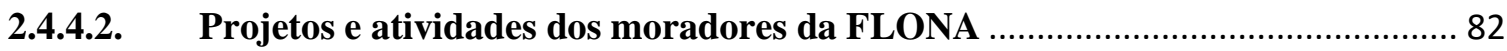

2.4.4.3. Programas do Plano de Gestão Territorial e Ambiental (PGTA) da TI Jiahui

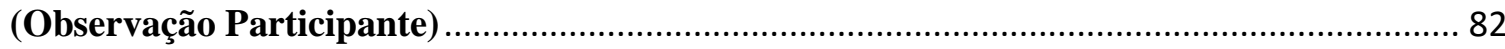

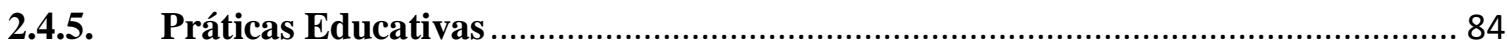

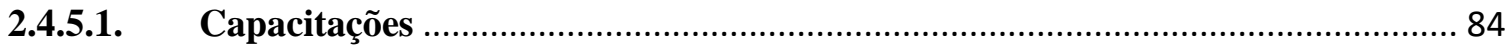

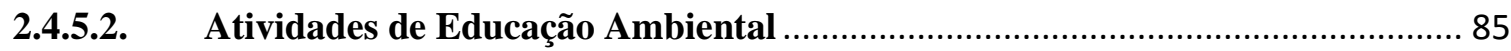

CAPÍTULO III. ANÁLISE DAS TRANSFORMAÇÕES TERRITORIAIS ..................................86

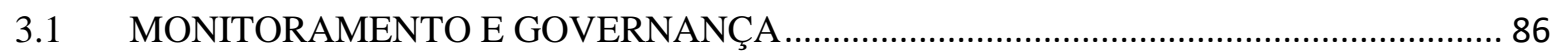

3.1.1 Instrumentos de Gestão (Indicadores Referência).......................................................... 86

3.1.2 Programa de Pesquisa em Biodiversidade (PPBIO) .................................................... 101

3.1.3 Projetos e iniciativas de Gestão Integrada e compartilhada ......................................... 102

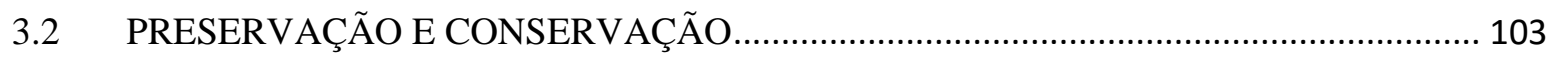

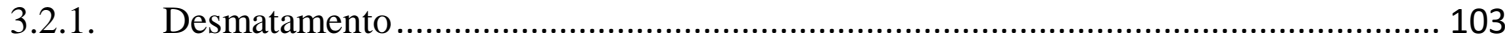

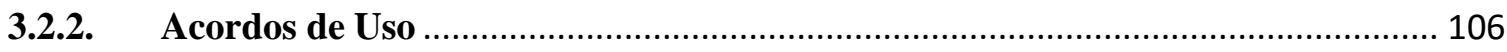

3.3. PREVENÇÃO E MITIGAÇÃO DE IMPACTOS NEGATIVOS ………........................... 107

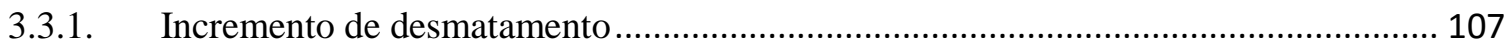

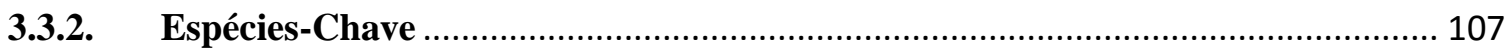

3.3.2. Número de Espécies Ameaçadas de Extinção............................................................... 109

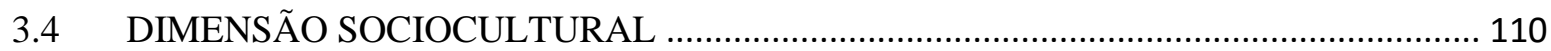

3.4.1 Agentes Ambientais Indígenas (AAI) Mulheres .......................................................... 110

3.4.2 Projetos e atividades dos moradores da FLONA ……............................................. 111

3.4.3. Programas do Plano de Gestão Territorial e Ambiental (PGTA) da TI Jiahui... 112 


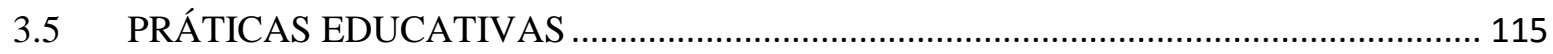

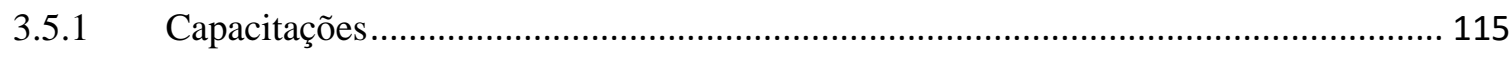

3.5.2 Atividades de Educação Ambiental .................................................................... 116

3.6 TRANSFORMAÇÕES TERRITORIAIS, POLÍTICAS DE GESTÃO E CENÁRIOS

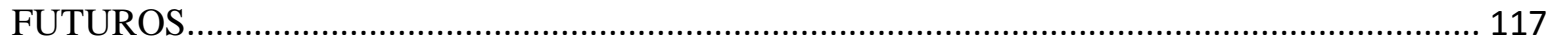

CONSIDERAÇÕES FINAIS ...........................................................................................................................130

Referências........................................................................................................................................................................134 


\section{APRESENTAÇÃO}

A escrita dessa pesquisa foi um aprendizado intenso que me exigiu, em processos simultâneos, amadurecimento enquanto pesquisadora, geógrafa e mulher no mundo. Este trabalho finaliza um ciclo de oito anos dedicados à Geografia, um período de resistências necessárias pelas questões de classe social e gênero. A finalização deste trabalho coincide com o encerramento de uma fase importante e marca o início das experiências da terceira década de minha vida. Tudo isso atribuiu intensidade ao processo de aprendizado e produção do conhecimento aqui almejado.

O caminho percorrido até a Pós-Graduação em Geografia, da Universidade de Brasília, teve início em 2008, na Universidade Federal de Goiás. Durante a graduação, o interesse pela abordagem territorial surge de uma inquietação em relação ao diálogo entre as linhas de pesquisa geográficas. Um pensamento centrado na importância da função social da ciência, e na visão ampla que tal papel requer, era recorrente.

A cada disciplina cursada, a cada viagem de campo e a cada trabalho realizado, tornava-se mais evidente que a transdisciplinaridade retornava aos vários setores da sociedade, inclusive à academia. Isso trouxe outro pensamento constante, o de que o mínimo que uma ciência pode realizar, para acompanhar as transformações do mundo, é o diálogo entre suas próprias linhas de pesquisa.

Tais pensamentos nortearam a busca e a realização de estudos no âmbito do Programa de Iniciação Científica do Conselho Nacional de Pesquisa e Tecnologia (CNPq). Foram desenvolvidas duas pesquisas ${ }^{1}$ fundamentadas na abordagem territorial. O território, enquanto categoria de análise, forneceu subsídios para a busca de uma abordagem integrada.

\footnotetext{
${ }^{1}$ ARANTES, M.M. ALMEIDA, M.G. O saber fazer do povo Kalunga na conservação da biodiversidade do Cerrado. Revista Élisée. 2012. Vol. 1 N.2 ISSN: 2316-4360, p.p 51-70. Este trabalho abordou o processo de territorialização do povo Kalunga no norte goiano.

ARANTES, M. M. ; CHAVEIRO, E.F. As representações do espaço urbano: a praça universitária sob perspectivas integradas. In: 63ª Reunião Anual da SBPC, 2011, Goiânia. 63ª Reunião Anual da SBPC, 2011. Neste trabalho a Praça Universitária, em Goiânia, foi abordada como território de resistência, sua dimensão cultural foi o foco principal.
} 
Posteriormente, a elaboração do trabalho de monografia ${ }^{2}$ também foi baseada no exercício de pesquisar por meio da abordagem territorial. Em tal exercício o esforço metodológico foi realizado no sentido de trabalhar com algumas das múltiplas dimensões territoriais, observando suas (inter)relações.

No processo de aprendizagem, os referidos trabalhos representam o ponto de partida da busca por uma abordagem geógrafica integrada do/no(s) território(s). Nestes, foram realizados recortes temáticos diferentes, mas tiveram em comum a perspectiva de abordagem territorial que encontra continuidade nesta pesquisa.

Em 2014, no Departamento de Geografia (GEA) da UnB, tive a oportunidade de contar com as contribuições do professor Everaldo Costa, durante o curso da disciplina de Teoria e Métodos em Geografia. Nessas aulas encontrei espaços de diálogo que proporcionaram reflexões preciosas acerca dos métodos e das filiações filosóficas na pesquisa geográfica. A densidade de tais reflexões foi 'moldada' conforme a proposta do pré-projeto e, posteriormente, delimitada no projeto de pesquisa. Nesta fase, o auxílio do professor Neio Campos, durante a disciplina Seminário de Dissertação, foi fundamental para superar o desafio que foi a construção do objeto de pesquisa em meio a tantas ideias. Por fim, o reforço da técnica na disciplina Sistema de Informação Geográfica (SIG), facilitada pelo prof. Renato Guimarães, importante para as representações cartográficas desta pesquisa.

A experiência com o bioma Amazônia iniciada em 2013 com os trabalhos desenvolvidos na Equipe de Conservação da Amazônia (ECAM) também é parte da escolha por esta pesquisa. Esta experiência de trabalho foi a inspiração do recorte temático e um espaço fértil para meu trabalho como geógrafa em parceria com comunidades tradicionais.

Influenciada por cada referência citada, esta pesquisa apresenta, sobretudo, uma proposta metodológica embasada na tentativa de compatibilizar uma visão de mundo integradora, ao rigor do conhecimento científico, na perspectiva geográfica.

\footnotetext{
${ }^{2}$ ARANTES, M. M. . O território religioso vale do amanhecer: um relato histórico, político e cultural. Ateliê Geográfico (UFG), v. 8, p. 231-251, 2014
} 


\section{INTRODUÇÃO}

A preocupação em se delimitar áreas de proteção aos sistemas naturais da Terra data dos séculos XVIII e XIX. O grande marco da criação de áreas protegidas no ocidente se deu a partir do primeiro Parque Nacional do mundo, o Yellowstone, fundado em 1872 nos Estados Unidos. No Brasil, o Parque Nacional do Itatiaia, criado em 1937 no Rio de Janeiro, é que demonstra a inserção do país na iniciativa de proteção ambiental, via delimitação de áreas protegidas. Posteriormente, uma estrutura de políticas públicas é construída no país em função da questão ambiental. Em 1981, surge no Brasil a Política Nacional de Meio Ambiente (PNMA) que constitui o Sistema Nacional do Meio Ambiente (SISNAMA) e traz, entre outras diretrizes, a proteção dos ecossistemas por meio da preservação de áreas representativas (OLIVEIRA, 2002).

No âmbito do SISNAMA, o Conselho Nacional de Meio Ambiente (CONAMA) está inserido como órgão consultivo e deliberativo, dentre suas atribuições está o acompanhamento da implementação do Sistema Nacional de Unidades de Conservação da Natureza (SNUC). Nessa estrutura de políticas públicas ambientais, o SNUC é responsável pelas normas de implementação e gestão das Unidades de Conservação (UCs). Estão previstos no SNUC dois grupos de UCs: proteção integral e uso sustentável. No primeiro grupo, o objetivo é preservar, admitindo-se apenas o uso indireto; já no segundo grupo o intuito é conservar, visando a integração entre conservação da natureza e uso dos recursos naturais (BRASIL, 2000).

Diante do exposto pode-se afirmar que a questão ambiental está incluída nas Políticas Públicas federais por meio dos dispositivos previstos na PNMA, especialmente àqueles que tratam da implementação e gestão de áreas protegidas. Nesse contexto, as UCs representam ferramentas do ordenamento territorial centrado no poder do Estado. As normas estatais direcionadas a tais áreas fazem parte da gestão e do uso dessas porções do território nacional, exercendo, sobre estas o poder de criá-las, manté-las e ainda, de direcionar os tipos de interação social nestes espaços.

As Terras Indígenas (TIs) também são caracterizadas como áreas protegidas integrantes da estrutura de gestão do Estado ${ }^{3}$. No entanto, a concepção de preservação e

\footnotetext{
${ }^{3}$ Não há legislação que defina, especificamente, o conceito de Áreas Protegidas. Mas, é de amplo conhecimento que se trata de UCs, TIs, Terras Quilombolas e áreas destinadas à proteção como as Áreas de Proteção Permanente (APPs). Programas governamentais, como por exemplo, o Plano Nacional de Áreas Protegidas (PNAP), apresentam diretrizes e estratégias de ação considerando, além das UCs, também os territórios de ocupação tradicional.
} 
as normas de demarcação e gestão das TIs fazem parte de outro setor: o das políticas públicas indigenistas. Os dispositivos de estruturação desse setor se diferenciam daqueles da mencionada política ambiental. Em síntese, a política indigenista em construção no Brasil, se fundamenta na relação entre os interesses do Estado e dos povos originários dessas terras. Por conta desse histórico, a ideia de conservação da natureza, vista nas estruturas de tal política, é pautada pelo modo de vida indígena. Desse modo, entende-se que os dispositivos voltados à política indigenista brasileira envolvem as demandas ambiental e indígena ao mesmo tempo. No entanto,ocupam apenas o setor indigenista na estrutura de gestão estatal.

A demarcação de terras indígenas é o eixo central de estruturação da política indigenista. Alguns marcos legais representam a forma de atuação do poder público em tal demanda. A demarcação de terras indígenas pelo Estado faz parte das imputações atribuídas à União por meio do Art. 231 da Constituição Federal de 1988. Tal ação encontrava previsão no Estatuto do Índio (Lei № 6.001 de 19 de dezembro de 1973) regulamentado pelo Decreto $\mathrm{n}^{\mathrm{o}} 1.775$ de 1996, que determina os procedimentos para a demarcação.

Mas, atualmente o Estatudo do Índio deve ser entendido a luz da Constituição Federal, pois tal Lei não considerou a autonomia dos povos indígenas. Ainda que tal legislação tratasse dos procedimentos de demarcação que garantia aos indígenas o direito à terra, era embasada na perspectiva de que em dado momento a cultura indígena seria extinta, sendo tomada pela cultura ocidental. Esse processo denominado como transição para a "comunhão nacional" previa a necessidade do acompanhamento estatal, a ser realizado pelo então Serviço de Proteção ao Índio (SPI) que veio a se transformar na Fundação Nacional do Índio (FUNAI).

Nesse sentido, a Constituição Federal assegurou o princípio do respeito à diversidade, e fez com que aquela perspectiva assimilacionista ${ }^{4}$ não fosse recepcionada. Assim, propugna o Artigo 231 pelo reconhecimento da cultura indígena sobre seus

\footnotetext{
${ }^{4}$ Corrente que preconiza a assimilação de culturas 'periféricas' pelas culturas dominantes. Nesta perspectiva é esperado que a cultura indígena passe por uma transição e se adapte à cultura ocidental. Tal consepção foi mencionada em 1900 durante discurso republicano realizado em comemoração ao quarto centenário do descobrimento do Brasil. Na ocasião, André Gustavo Paulo Frontin disse que os índios deveriam ser assimilados ou eliminados. Conforme analisa Lopes (2014, p.89) "A concepção de assimilação, que o republicano proferia na carta, trazia consigo a noção de incorporação do índio à sociedade nacional, rejeitando seus modelos sociais, crenças e influenciando as políticas legislativas posteriore"
} 
territórios. A TI é, portanto, o espaço de exercício dessa diversidade e da autonomia indígena.

Diante do exposto torna-se evidente que tanto UCs quanto TIs são áreas de conservação e proteção de grande importância no Brasil. Juntas, guardam boa parte das riquezas em biodiversidade dos biomas brasileiros. Atualmente, o cenário de áreas protegidas no país é composto por 462 terras indígenas demarcadas, e outras tantas em processo de estudo para demarcação e/ou correção de área e 320 UCs da esfera federal, além das estaduais e municipais não contempladas neste estudo.

A problemática existente no referido cenário está relacionada à situação de sobreposição de UCs de uso sustentável e TIs. Em tese, tais áreas - elencadas para esta pesquisa e doravante denominadas territórios protegidos ${ }^{5}$ - se complementam na conservação socioambiental. Mas na prática, a sobreposição pode representar um desafio para o cumprimento do objetivo desses territórios, que é alcançar a conservação na relação entre sociedade e natureza.

No Brasil, as sobreposições entre territórios protegidos são mais recorrentes no bioma Amazônia. Haja vista, a princípio, a dimensão da TIs e a alta concentração de UCs em tal bioma. Até o ano de 2004 foram registrados 55 casos de sobreposições, destes 42 encontravam-se na Amazônia, o que representava mais de $70 \%$ dos casos do país. O estado do Amazonas se destacava com 29 sobreposições, sendo o caso da TI Alto Rio Negro o mais expressivo, pois incidiam sobre seu território 11 Florestas Nacionais (ISA,2004, p.592).

Atualmente, estas 11 UCs foram extintas prevalecendo apenas a TI Alto Rio Negro. Desse modo, ainda existem 44 territórios protegidos em situação de sobreposição no Brasil (Figura 1). Desse total, 30 casos estão na Amazônia, sendo 18 só no estado do Amazonas, ou seja, 68\% das sobreposições localizam-se nos estados amazônicos. Vale ressaltar que essa a situação está em constante debate entre o movimento indígena e os entes governamentais responsáveis. Isso significa que é possível ocorrer mudanças nesse cenário, como por exemplo, a extinção de algumas

\footnotetext{
${ }^{5}$ Nesta pesquisa utiliza-se o termo Territórios Protegidos e não áreas protegidas, como geralmente é utilizado. A escolha por este termo se deve a necessidade de enfatizar a abordagem proposta nesta pesquisa, na qual a reflexão sobre UCs e TIs, em sobreposição, é feita com base em suas formas representadas nos mapas por meio da delimitação de suas fronteiras - e nos conteúdos - vistos nas territorialidades, ou seja, nos processos de interação entre sociedade e natureza que resulta na criação, transformação, continuidade e sentido desses territórios. Tal entendimento será detalhado ao final do cap. 1.
} 
UCs como ocorreu no caso da TI Alto Rio Negro. Por isso é importante uma constante atualização desses dados para melhor representar a realidade das sobreposições. 


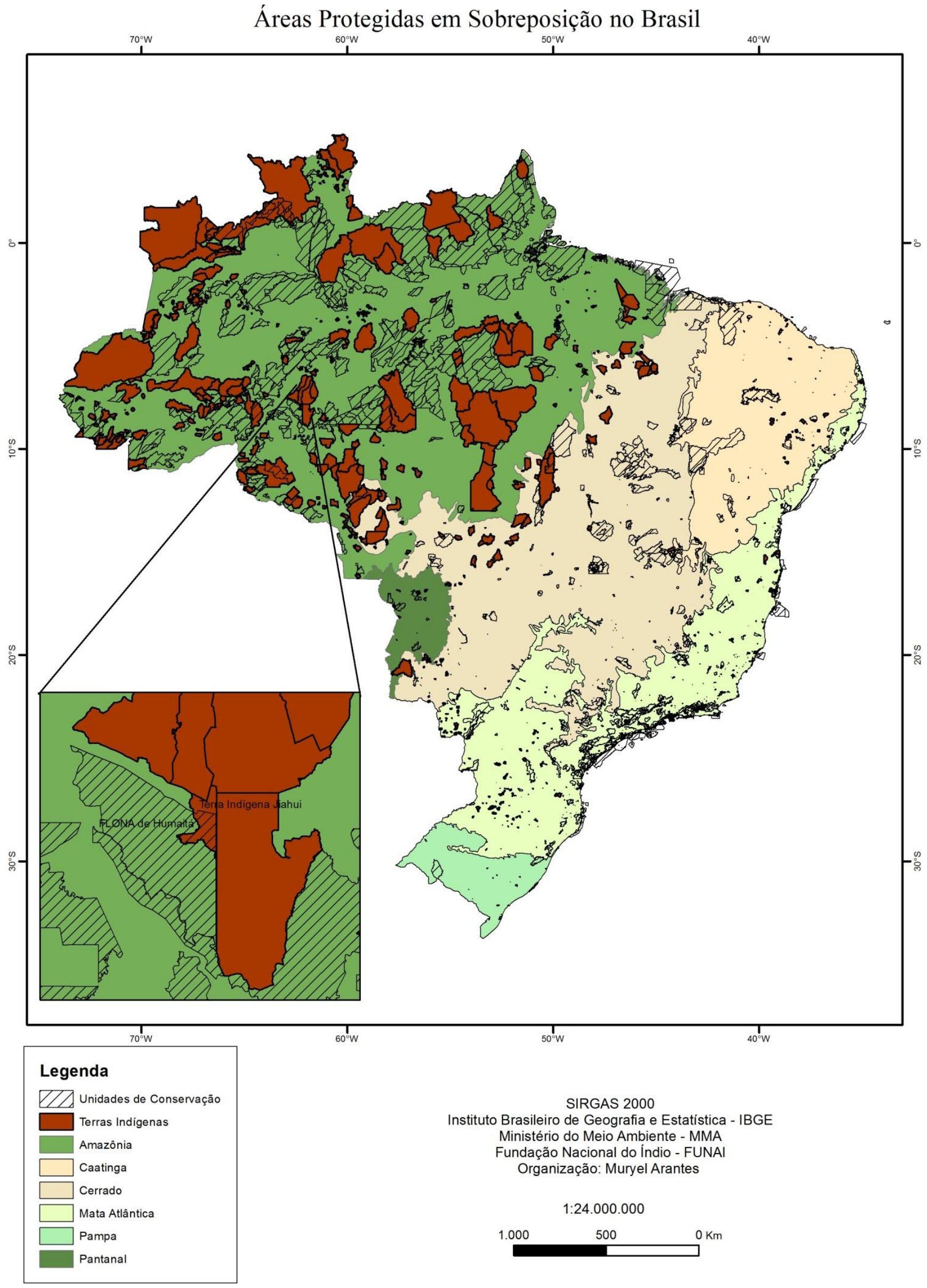

Figura 1 - Sobreposições entre territórios protegidos no Brasil 
Em detrimento da riqueza do bioma e da contundente presença de territórios protegidos, o desmatamento vem avançando em cada estado amazônico. De outubro de 2013 a outubro de 2014 houve um aumento de $467 \%$ de desmatamento na Amazônia Legal. Os maiores focos ficaram concentrados nos estados de Rondônia (27\%), Mato Grosso (23\%), Pará (22\%) e Amazonas (13\%), já os estados menos impactados foram Roraima (9\%), Acre (5\%) e Amapá (1\%).

Em contextos como o de avanço do desmatamento, os territórios protegidos desempenham papel de resistência a esse tipo de processo, que tem como consequência a degradação. Ainda que também sejam impactados pelo desmatamento, guardam uma cobertura vegetal mais preservada. O Amapá, estado com o menor índice de desmatamento, ilustra bem tal afirmação pois possui mais de $90 \%$ de sua área composta por territórios protegidos (Fonseca, A., Souza Jr., \& Veríssimo, A. 2014, p.10).

Os territórios protegidos da Amazônia são de extrema importância para o controle da degradação ambiental. Sobretudo por conter boa parte do desmatamento que desencadeia outros impactos socioambientais. Por outro lado, é necessário considerar também que para além dessa função de proteção, existe a necessidade de se garantir o uso dos recursos naturais em prol do bem-estar da sociedade. Principalmente quando se trata de UCs de uso sustentável, nas quais objetivo é integrar conservação da natureza e uso dos recursos naturais.

O desafio de gestão, nas UCs de uso sustentável, é criar condições para o uso de maneira que não prejudique os cenários futuros. Assim são estabelecidos critérios e normativas para possibilitar a conservação ambiental de forma conjunta com a dinâmica social. Dessa forma, também faz parte do objetivo dessas UCs evitar o esgotamento de recursos naturais.

Neste contexto, o uso e a estrutura de gestão são centrais, pois estão diretamente relacionados ao princípio de conservação de TIs e UCs de uso sustentável. Quando há sobreposição entre esses territórios protegidos, o desafio de gestão se torna maior, pois envolve diferentes formas de uso e gestão da mesma área (a de sobreposição entre os dois territórios), sendo ambas respaldadas oficialmente. Em outras palavras, trata-se de uma questão que do ponto de vista prático do uso se torna divergente, mas que na perspectiva oficial das políticas públicas encontra-se respaldada como se fosse convergente. Tal situação ocorre no contexto de um modelo de gestão baseado em políticas públicas setoriais, a ambiental e a indigenista. 
A gestão dos territórios protegidos é um fator elementar na reflexão aqui proposta, pois é parte da dinâmica territorial relacionada às Territorialidades. Do ponto de vista empírico, a estrutura de gestão estatal é responsável pela criação/reconhecimento e continuidade desses territórios. Tal estrutura é composta, basicamente, pelas políticas públicas - suas diretrizes, objetivos e instrumentos de gestão. Na perspectiva teórica, a estrutura de gestão pode ser compreendida como as Territorialidades existententes tanto na esfera do poder público quanto na escala local.

Nesse contexto, a gestão dos territórios protegidos em sobreposição - objeto de estudo dessa pesquisa - é abordada por meio de aportes teóricos dos conceitos de território e Territorialidade. Tal abordagem ocorre em duas escalas e dois eixos analíticos. Trata-se da escala nacional, cujo eixo analítico consiste nas políticas públicas federais, e da escala local concebida na perspectiva dos territórios cujo eixo analítico está nas transformações territoriais ${ }^{6}$.

Tal abordagem se destina a analisar, de forma conjunta, as políticas públicas ambiental e indigenista e a dinâmica dos territórios protegidos em sobreposição. As políticas (escala nacional) serão analisadas por meio de suas diretrizes e objetivos e os territórios (escala local), por meio das transformações territoriais. Esse enfoque é o fio condutor da fundamentação teórica, metodológica e empírica da pesquisa.

\footnotetext{
${ }^{6} \mathrm{O}$ termo transformações territoriais, adotado nesta pesquisa, tem a função de representar a dimensão espacial centrada nos mecanismos de gestão, nos usos e impactos destes nos sistemas naturais, organizações sociais e culturais.Também pode ser entendido como dinâmica territorial.
} 


\section{PRESSUPOSTOS DA PESQUISA}

\section{a) OBJETO DE ESTUDO}

A gestão dos Territórios Protegidos em sobreposição na Amazônia brasileira abordados na perspectiva da escala nacional - pelas políticas públicas - e na escala local - pelas transformações territoriais. As dimensões política e ambiental desses territórios serão estudadas com embasamento dos conceitos de Território e Territorialidades.

\section{b) PESQUISA BIBLIOGRÁFICA - CONCEITO DE TERRITÓRIO}

A abordagem territorial, aqui proposta, se dá a partir de duas bases fundamentais à construção teórico-metodológica desta pesquisa. A primeira está relacionada ao arcabouço conceitual construído na Geografia acerca do território, e a segunda se insere no contexto temático dos territórios protegidos. Com isso, o intuito é alcançar o entendimento das possibilidades e limites do território enquanto instrumento de produção do conhecimento científico de caráter geográfico e a partir de tal entendimento dá-se a ênfase necessária às especificidades dos territórios aqui estudados. O fito é partir de uma base científica consolidada em direção à diversidade e à multiplicidade do(s) território(s).

A referida abordagem vem sendo construída e consolidada desde os estudos clássicos de Friedrich Ratzel ${ }^{7}$ e Paul Vidal de La Blache ${ }^{8}$. Pode-se dizer que o território enquanto categoria de análise teve suas bases epistemológicas pautadas na geografia clássica alemã e francesa. Na perspectiva clássica alemã, uma aproximação com o Darwinismo e ao mesmo tempo com a política integrou a concepção do conceito de território vista na teoria do espaço vital. Na França, ainda que numa perspectiva regionalista, os estudos do homem e do meio ganharam espaço a partir das publicações de La Blache (ITABORAHY, N.Z. 2010).

Assim, os elementos fundamentais do território foram introduzidos no campo do saber geográfico desde o período caracterizado como Geografia Clássica. Em síntese,

\footnotetext{
${ }^{7}$ Antropogeografia - estudos interdisciplinares com visão da terra ligada ao homem.

${ }^{8}$ Revue Annales de Géographie - estudo do homem e sua relação com o meio ambiente.
} 
trata-se de poder, política e ambiente. Nesse sentido, o que correlaciona esses elementos na configuração dos territórios, é a relação entre sociedade e natureza inerente a eles. Tais elementos guardam em suas origens uma gama de temáticas capaz de gerar vários desdobramentos e recortes analíticos dos quais se ocuparam os geógrafos que promoveram a dita renovação pós década de 1950.

O referido período foi caracterizado como revolucionário devido ao início de um movimento de "cientifização" das ciências sociais. No contexto do pós-guerra, havia uma necessidade de rompimento com o dito romantismo do pensamento histórico que, segundo críticas, havia se deixado tomar entre a ideologia burguesa e a ideologia stalinista. Assim, o estruturalismo surge como fenômeno intelectual a influenciar as ciências humanas na tentativa de atribuir-lhes caráter científico, conforme lembram Camargo\&Júnior (2004):

As ciências sociais se viram obrigadas a forjar reformulações internas, em função das rápidas inovações tecnológicas e muitas delas puseram fé no aparente explanatório de ferramentas teóricoquantificantes, implementadas no pós-guerra. O aparecimento da teoria dos sistemas, do método estruturalista e, no campo mais operacional (pragmático), das técnicas estatísticas e dos computadores, exemplificam o novo rol de recursos científicos colocados à disposição dos pesquisadores (CAMARGO, J.C.G. \& JÚNIOR, D.F.C.R. p. 356)

Como resultado dessas transformações surge uma "Nova Geografia" pautada em métodos quantitativos aplicados à estudos regionais - a Geografia Teorética e Quantitativa ou Neopositivista. O uso da matemática na elaboração de modelos foi aplicado às análises regionais que floresceram durante a década de 1960. Em relação aos efeitos desse movimento nas demais ciências sociais, cabe ressaltar o nível de apropriação do estruturalismo na Antropologia. Muito embora a economia tenha se destacado nesse aspecto, em função do desenvolvimento da econometria, a Antropologia avançou no mesmo sentido desenvolvendo a linguística social tão difundida atualmente (DOSSE, F. 1945/1966).

Diante dessa conjuntura na qual se encontrava as ciências sociais e a Geografia na década de 1950, é possível compreender por que pesquisadores dedicados a estudar a trajetória do território partem desse recorte temporal para discuti-lo. A Geografia encontrava-se diante de novas técnicas, novos métodos que inicialmente causaram 
rupturas, mas que no decorrer dos anos seguintes foram compreendidos como elementos de uma mesma realidade. A quebra de paradigmas transformou a concepção de território, até então relacionada ao conceito de Estado-Nação e às ciências naturais, através da inserção de novos elementos fertilizados no cerne de tal movimento de rupturas.

Nesse sentido, Saquet (2007) discute as distintas abordagens e concepções do conceito de território que se colocam como produto das mudanças que ocorreram no referido período na filosofia, nas ciências sociais e no campo do real. Desse modo, o autor se posiciona a favor de uma abordagem territorial que

considere as articulações/interações existentes entre as dimensões sociais do território, em unidade entre si e com a natureza exterior do homem, o processo histórico e a multiescalaridade de dinâmicas territoriais [...] como uma forma corrente para o entendimento dos sujeitos e processos das problemáticas socioespaciais.

Para a construção de tal abordagem, o referido autor considera importante ressaltar o contexto de reelaboração da ciência geográfica $(1950-60 ; 1970)$ a partir da qual identifica quatro tendências caracterizadas pelo desenvolvimento de diferentes métodos e abordagens aplicados ao conceito de território. Segundo o autor, trata-se das seguintes fases:

- Discussão teórico-metodológica

Esse enfoque ganhou consistência no período compreendido entre a década de 1960 e final de década de 1970. Geógrafos como o italiano Giuseppe Dematteis, o francês Claude Raffestin e também filósofos como Deleuze e Guatarri, dentre outros, realizaram importantes contribuições acerca da reflexão teórica e metodológica da abordagem territorial e do próprio conceito de território, a qual pode-se atribuir uma característica mais social.

- Compreensão da dimensão geopolítica do espaço

Os expoentes dessa tendência foram Jean Gottmann, Claude Raffestin, Edward Soja e Paul Guichonnet. Nessa abordagem o território é concebido, principalmente, como parte da estrutura de poder do Estado. Adquirindo, portanto, grande importância na geopolítica em escala nacional e internacional.

- Desenvolvimento Territorial - Reestruturação do Capital 
Esse viés de abordagem territorial se desenvolveu também entre as décadas de 1960 e 1970 a partir dos estudos de Cologero Muscaà, Arnaldo Bagnasco, Alberto Magnaghi, Diacomo Becattini, Giuseppe Dematteis, dentre outros. Essa abordagem possui forte influência da Economia.

- Semiológica

Impulsionada principalmente pelo filósofo Umberto Eco, essa abordagem apresenta um caráter cultural que teve início da década de 1970.

Essas abordagens evidenciaram as seguintes perspectivas acerca do território: econômica, pautada no materialismo histórico dialético; geopolítica embasada principalmente nas estruturas de poder; as dinâmicas política e cultural, simbólico identitária tratando-se das representações sociais com auxílio dos aportes teóricos da fenomenologia e por fim, a perspectiva da sustentabilidade ambiental que surge a partir de 1990 e vem ganhando representatividade nos dias atuais, mas que não apresenta claramente uma filiação filosófica, o que é compreensível dado o pouco tempo de emersão da questão ambiental no Brasil (SAQUET, 2007).

O movimento de renovação pós década de 1950 se concretizou no Brasil, inicialmente, com o foco no espaço geográfico abordado a partir de uma perspectiva materialista. Mas, no processo de renovação, o conceito de território, compreendido a partir das relações de poder, foi sendo incorporado às leituras espaciais. Essa inserção foi claramente política e baseada na obra Por uma Geografia do Poder, de Claude Raffestin. Vale ressaltar também que nesse contexto a Geografia Cultural conquistou espaço principalmente na década de 1970 e com isso a dimensão cultural simbólica do território também ganhou força (SAQUET, M.A, 2009, p.42).

O poder concebido a partir das relações sociais em detrimento de uma vontade divina, foi debatido a partir das ideias de Niccolò Machiavelli, principalmente em sua obra mais difundida: $O$ Príncipe. A importância dessa ruptura para as futuras análises consistiu na possibilidade de se observar a materialização de múltiplas relações de poder existentes na sociedade. O que sucedeu esse momento histórico evidenciou outras relações de poder, outros protagonistas e, consequentemente, outras concepções e abordagens territoriais. Sem com isso abandonar por completo a importância do Estado e suas interferências no espaço, na formação dos territórios, mas lançando o olhar para outros elementos. 
As revoluções do século XVIII nas américas e na França evidenciaram uma ligação entre soberania territorial e população nacional, o que reforçou um complexo sistema de mercado unificado estabelecido entre as bases do território nacional e internacional. Esse movimento se acentua no séc. XIX e assume centralidade no séc. XX. Assim, o território cujas funções delimitadas são abrigo, proteção e soberania deixa de vigorar como funções dominantes com o advento de um novo momento social, durante o qual

os meios de comunicação e as invenções beligerantes articulam Estados, ameaçando-os, condicionando uma nova ordem, que é global e plural, porém sem eliminar o território nem o Estado. Agora, os territórios, com novos significados, estão justapostos através das fronteiras e relacionados, política e geograficamente, no nível internacional, no qual, há uma fluidez e uma complementaridade moderna. (SAQUET, M. 2007p. 29)

$\mathrm{Na}$ Geografia, a noção de poder se insere na abordagem territorial principalmente a partir das contribuições de Claude Raffestin, realizadas com base nas reflexões de Michel Foucault. Para ele, “Faucault não afirmou que tudo é poder, mas que cada relação é poder (...)" (Raffestin, 1983, p. 65 APUD Saquet, 2007, p. 33) Com base nesse argumento, pode-se inferir que se o poder é inerente a existência do território, desde séculos remotos, e o mesmo possui um caráter relacional que se concretizam em várias dimensões, a abordagem territorial deve considerar, primordialmente as múltiplas escalas existentes nos fenômenos socioespaciais.

Neste contexto do séc. XVIII a Geografia se institucionaliza com uma proximidade do Estado e do pensamento burguês, assim, a ciência passou a abordar os quadros naturais. Neste momento Friedrich Ratzel se dedica a uma aproximação entre os recursos naturais e a dimensão política do território. O referido autor destaca os seguintes pontos de influência da natureza sobre o homem: como indivíduo com corpo e espírito; acelerando ou dificultando a expansão de grupos étnicos; impondo condições geográficas que favorecem a miscigenação ou o isolamento e influenciando na constituição social de cada povo, como recurso natural. Desse modo, a natureza e o Estado assumem centralidade em sua argumentação e compreensão do conceito de território tratado como solo ou como Estado-Nação. (SAQUET, 2007, p1. 30) 


\section{c) DEFINIÇÃO DO PROBLEMA}

Tanto a criação de UCs quanto o procedimento de reconhecimento e demarcação de TIs encontram respaldo na Constituição Federal. Além de admitir a importância da conservação ambiental e do reconhecimento dos territórios tradicionais, a Carta Magna brasileira atribui ao Estado o dever de criar e controlar o uso dos espaços territoriais protegidos, as UCs, e também de garantir ademarcação das TIs. Em tese, as diretrizes de conservação da natureza e de reconhecimento dos territórios tradicionais são complementares e benéficas para todas as dimensões do território nacional.

Porém, os mecanismos de atuação do Estado nas duas demandas não funcionam de forma complementar, pois fazem parte de políticas diferentes e acabam se colocando em justaposição. Um exemplo desse descompasso é a quantidade de TIs e UCs em situação de sobreposição no Brasil, o que causa uma série de conflitos, disputas territoriais e entraves para uma gestão que se proponha socioambiental.

Tal situação se torna complexa justamente por ambos os territórios encontrarem respaldo na legislação e nas políticas públicas para garantir sua existência e viabilizar sua gestão. Nesse caso, não se trata de um uso e ocupação irregular das áreas protegidas, como no caso das UCs de proteção integral, e sim de territórios legítimos no âmbito de suas respectivas políticas (ambiental e indigenista). Assim, os mecanismos de gestão é que se diferenciam.

Nesse contexto, as diferenças de estrutura e significados presentes nos mecanismos de gestão são o cerne de tal problemática. A discussão que se coloca nesse sentido está relacionada à efetividade da gestão praticada de forma concomitante em áreas sobrepostas. Esta prática é questionável tanto do ponto de vista da conservação ambiental, quanto no que diz respeito ao direito de todos aos recursos naturais, sobretudo quando se trata de populações tradicionais.

Trata-se de um questionamento complexo cuja resposta requer uma compreensão da situação que supere a simples constatação de que a sobreposição de territórios protegidos é um problema para a questão ambiental e indígena no Brasil. É necessário indicar os aspectos concretos e teóricos que contribuam para a reflexão sobre tal problemática. Nesse sentido, esta pesquisa tem o intuito de contribuir a partir da análise das políticas públicas em correspondência com as transformações territoriais. 


\section{d) HIPÓTESE DE TRABALHO}

A hipótese do trabalho é que os mecanismos de gestão das políticas públicas responsáveis pelo controle dos Territórios Protegidos se tornam fatores de degradação socioambiental em caso de sobreposições. Em outras palavras, os instrumentos das políticas públicas ambientais se tornam contrários às diretrizes das próprias políticas quando desenvolvidos em sobreposição com as indigenistas.

\section{e) METODOLOGIA}

A pesquisa proposta neste projeto é de caráter qualitativo, e como tal, pode ser caracterizada pela tentativa de uma compreensão detalhada dos significados e características situacionais (RICHARDSON, 1999, p.90). Adota-se aqui o pressuposto de que o conhecimento da realidade local (ou regional) fornece subsídios para o entendimento da totalidade que envolve o tema aqui abordado. Portanto, o trabalho será desenvolvido com os aportes do estudo de caso cujas ferramentas oferecem subsídios para o entendimento da totalidade a partir da particularidade.

Sobre a relevância do estudo de caso, Gil (1999) afirma que a análise de uma unidade de determinado universo possibilita a compreensão da generalidade, e fornece as bases para uma investigação mais abrangente. A escolha dessa metodologia se fundamenta, portanto, na necessidade de se conhecer, com maior detalhamento, a gestão dos territórios protegidos em sobreposição, e a partir de então ter subsídios para a discussão do tema numa escala de Amazônia.

Foram utilizadas as modalidades de pesquisa bibliográfica e documental. A primeira para fundamentação teórica e a segunda com o foco no SNUC, na PNGATI, e nos estudos realizados nos Territórios Protegidos. Para observar as transformações territoriais utilizou-se dados secundários de órgãos governamentais, estudos diagnósticos e entrevistas semi-estruturadas com a gestão da Flona. A observação participante também servirá como subsídio para a pesquisa, com a utilização dos seguintes instrumentos: trabalho de campo, diário de campo e registros fotográficos. Esta parte da pesquisa foi realizada no contexto de realização de oficina participativa para construção do Plano de Gestão Territorial e Ambiental da TI Jiahui.

A metodologia proposta foi realizada em três fases: descrição, classificação e interpretação. A primeira fase corresponde a caracterização da área de estudo e das políticas públicas, assim como o aprofundamento das bases teóricas que permeiam o 
tema. Na segunda fase apresenta-se os objetivos e as diretrizes das políticas públicas as quais dão origem a classificação destas. O agrupamento de temáticas relacionadas no cerne das políticas nortearam a escolha dos indicadores socioambientais para análise das transformações territoriais, por exemplo: grupo de objetivos e diretrizes relacionados à educação será analisado por meio de indicadores de capacitação.

Tais indicadores, quando selecionados, serão observados de acordo com o zoneamento e etnozoneamento (ferramentas espaciais de gestão). Ainda na segunda fase foi realizado o mapeamento das transformações territoriais na área de sobreposição da FLONA de Humaitá e da TI Jiahui. Na terceira e última etapa da pesquisa realizou-se uma análise das transformações territoriais. Por fim, a reflexão sobre a gestão dos territórios protegidos em sobreposição com base na relação entre as políticas públicas e as dinâmica territorial.

\section{i) Passos metodológicos}

As três etapas da pesquisa foram desenvolvidas com o objetivo de apresentar os seguintes conteúdos na redação dissertativa: aprofundamento dos aportes teóricos e das diretrizes das políticas públicas; leitura da realidade local e discussão dos resultados.

\section{$1^{\text {a }}$ Etapa}

- levantamento bibliográfico acerca das bases teóricas da pesquisa;

- estudo descritivo das políticas públicas (SNUC e PNGATI);

- caracterização da área de estudo (referencial empírico).

\section{$2^{\text {a }}$ Etapa}

- classificação dos objetivos e diretrizes das políticas públicas;

- seleção dos indicadores de transformações territoriais;

- mapeamento das transformações territoriais na área de sobreposição dos territórios protegidos.

\section{$3^{\text {a Etapa }}$}

- interpretação teórica e metodológica dos resultados e redação final da pesquisa. 


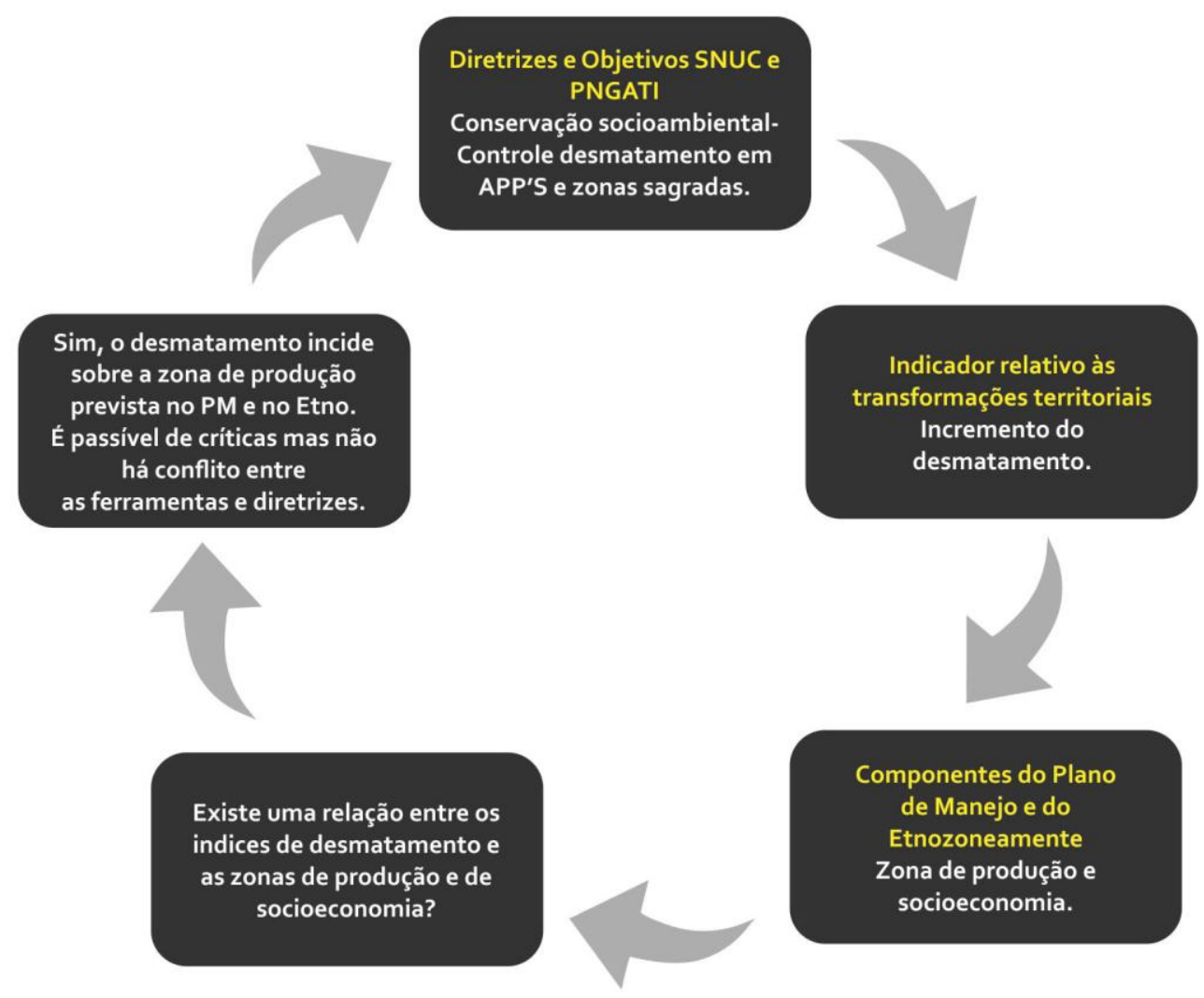

Figura 2- Fases e possibilidades do desenvolvimento da pesquisa

\section{i) Procedimentos Metodológicos}

O desenvolvimento da pesquisa foi realizado conforme os passos metodológicos já mencionados. Na primeira etapa foram realizados as pesquisas bibliográficas e documentais. O que consistiu em um levantamento sistemático da categoria Território na Geografia, estudo do SNUC e da PNGATI e levantamento dos estudos contendo dados primários dos territórios.

A partir dos resultados da primeira etapa foi realizada a classificação das políticas em cinco grandes grupos que representam grandes temas, são eles: Monitoramento e Governança; Preservação e conservação; Prevenção e Mitigação de Impactos Negativos; Dimensão Sociocultural e Práticas Educativas. O intuito da classificação que 
resultou na formação dos referidos grupos foi útil para representar as duas políticas nacionais e para direcionar a seleção de indicadores compatíveis com estas.

Com base nesses cinco grandes temas foram selecionados indicadores socioambientais com potencial de representa-los no chão dos territórios, contemplando assim, e de forma integrada, as diretrizes das políticas nacionais e a realidade local conforme cada tema. Assim foram selecionados os indicadores socioambientais de transformações territoriais.

Ainda nesta segunda fase da pesquisa, com os indicadores já definidos, iniciou-se o trabalho técnico de análise destes. O referido trabalho consistiu na manipulação dos dados de cada indicador o que envolveu técnicas de mapeamento realizado no software ArcGis 10.1, análise de dados secundários do governo e análise dos dados primários dos territórios, tais como contabilização de espécies em extinção, definição das espécieschave, etc.

O resultado de tais análise fundamentou a crítica feita as políticas públicas apresentadas na primeira etapa. Fechando assim uma análise integrada e cíclica, que se iniciou nas política nacionais, passou pela realidade dos territórios e retornou para embasar a reflexão crítica sobre tais políticas. 


\section{f) CARACTERIZAÇÃO DA ÁREA DE ESTUDO}

\section{i) As sobreposições da Amazônia - conforme recorte da pesquisa}

As sobreposições entre territórios protegidos na Amazônia, conforme delimitação desta pesquisa - UCs sustentáveis da esfera federal e TIs - estão localizadas nos estados do Acre (1), Amazonas (6), Mato Grosso (1), Roraima (1) e Rondônia (1). No total, são 10 casos de sobreposições que representam o enfoque desta pesquisa em todo bioma (ISA, 2004).

Tabela 1 - Lista dos Territórios Protegidos em Sobreposições da Amazônia Brasileira. Fonte: ISA, 2004 (adaptado).

\begin{tabular}{|c|c|c|}
\hline Estado & Terra Indígena & UC Federal - Uso Sustentável \\
\hline Acre & Jaminawa-Envira & Flona Santa Rosa do Purus \\
\hline \multirow{6}{*}{ Amazonas } & Andirá-Marrau & Flona de Pau Rosa \\
\hline & Betânia & Esec Jutaí-Solimões \\
\hline & Jiahui & Flona de Humaitá \\
\hline & Inauini-Tcuini & Flona de Mapiá-Inauini e Flona do Purus \\
\hline & $\begin{array}{l}\text { São Domingos do Jacapari } \\
\text { e Estação }\end{array}$ & Esec de Jutaí-Solimões \\
\hline & Yanomami & Flona do Amazonas \\
\hline Mato Grosso & Enawenê-Nawê & Esec lquê \\
\hline Roraima & Yanomami & Flona de Roraima \\
\hline Rondônia & Karitiana & Flona Bom Futuro \\
\hline
\end{tabular}

\section{i) Contexto sócioespacial da TI Jiahui}

A terra indígena Jiahui localiza-se no bioma Amazônia ao sul do estado do Amazonas, totalmente inserida no município de Humaitá-AM. O território faz parte de um cenário composto por outras áreas protegidas, pela BR-230 (Transamazônica) e pela abundância em recursos hídricos. A terra é cercada pelos rios Maici, à oeste, e Marmelos à leste, além dos vários igarapés que drenam o entorno e o interior de seus limites. A Transamazônica passa pelo território ao norte, na altura das aldeias Ju'i, 
Kawari e também da nova aldeia que se encontra em processo de abertura à beira da rodovia. Existem várias terras indígenas que fazem fronteira com o território Jiahui e ainda, a sobreposição de $60 \%$ de sua área total pela Floresta Nacional (FLONA) de Humaitá (Figura 3).

No que diz respeito às relações existentes no campo da biodiversidade e do etnodesenvolvimento, o território Jiahui se insere no Corredor Etnoambiental TupiKagawahiba ${ }^{9}$ (Figura 4), e em relação à dinâmica de relações sociais, a comunidade possui vínculos no município de Humaitá, e existe ainda uma forte ligação com o extremo norte de Rondônia, no município de Porto Velho (ECAM, 2013).

\footnotetext{
${ }^{9}$ A partir da década de 1980 a Amazônia capturou o imaginário do movimento ambientalista tornando-se foco das lutas para a conservação das florestas tropicais. A principal estratégia utilizada para proteger a biodiversidade dessas florestas foi a criação de UCs. No entanto, essas áreas protegidas se tornaram "ilhas" de biodiversidade num mar de devastação. Então, na década de 1990 o conceito de corredores ecológicos foi introduzido para superar este problema.Com a promulgação do SNUC este conceito foi abarcado sob a nomenclatura de mosaicos de áreas protegidas. Mas, nesse contexto, as especificidades das terras indígenas presentes em tais corredores/mosaicos ainda não era contemplada adequadamente. Então, com o estabelecimento da Política Nacional de Áreas Protegidas em 2006, que prevê espaço para a gestão ambiental das terras indígenas e que abre oportunidade para a criação da política de gestão das terras indígenas que veio em 2012, houve a oportunidade de incorporar as especificidades indígenas à essa escala dos corredores. Neste cenário, o projeto Garah Itxa lançou entre 2009 e 2012 a proposta de estabelecer os Corredores Etnoambientais, concebidos como um aperfeiçoamento das políticas anteriores dos corredores ecológicos e dos mosaicos de áreas protegidas. A ideia é reformular o conceito de corredor ecológico, incorporando diretamente as ações dos povos indígenas nas políticas de conservação e Desenvolvimento Sustentável . (Corredores Etnoambientais na Amazônia Ocidental - Principais resultados do Projeto Garah Itxa. Disponível em <www.iieb.org.br/index.php/download file/1073/268/>)
} 
Localização da Terra Indígena Jiahui e Floresta Nacional de Humaitá
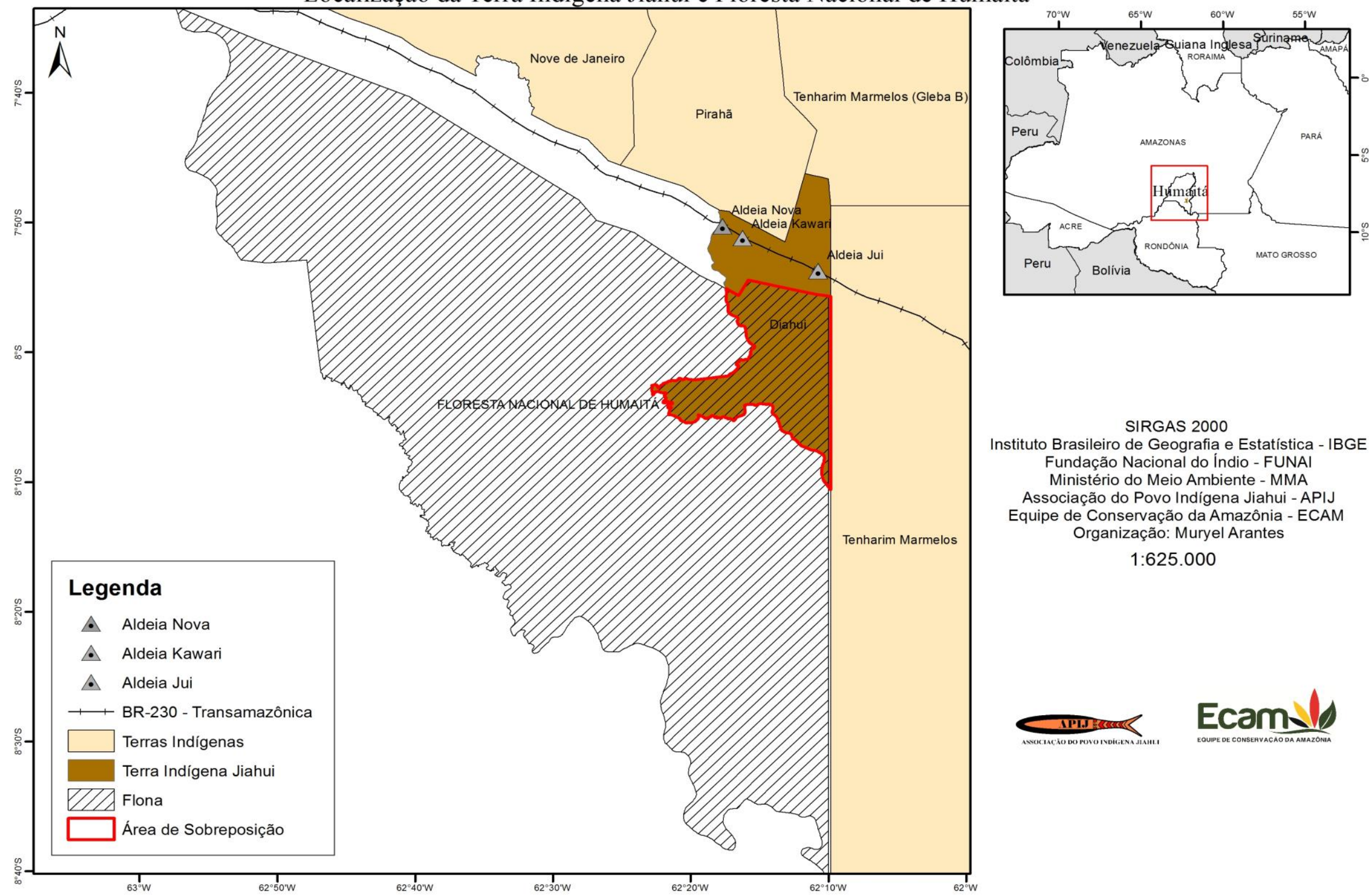

SIRGAS 2000

Instituto Brasileiro de Geografia e Estatística - IBGE Fundação Nacional do Índio - FUNAI Ministério do Meio Ambiente - MMA

Associação do Povo Indígena Jiahui - APIJ

Equipe de Conservação da Amazônia - ECAM Organização: Muryel Arantes

$$
1: 625.000
$$

Figura 3 - Mapa de localização da Terra Indígena Jiahui e da Flona de Humaitá 


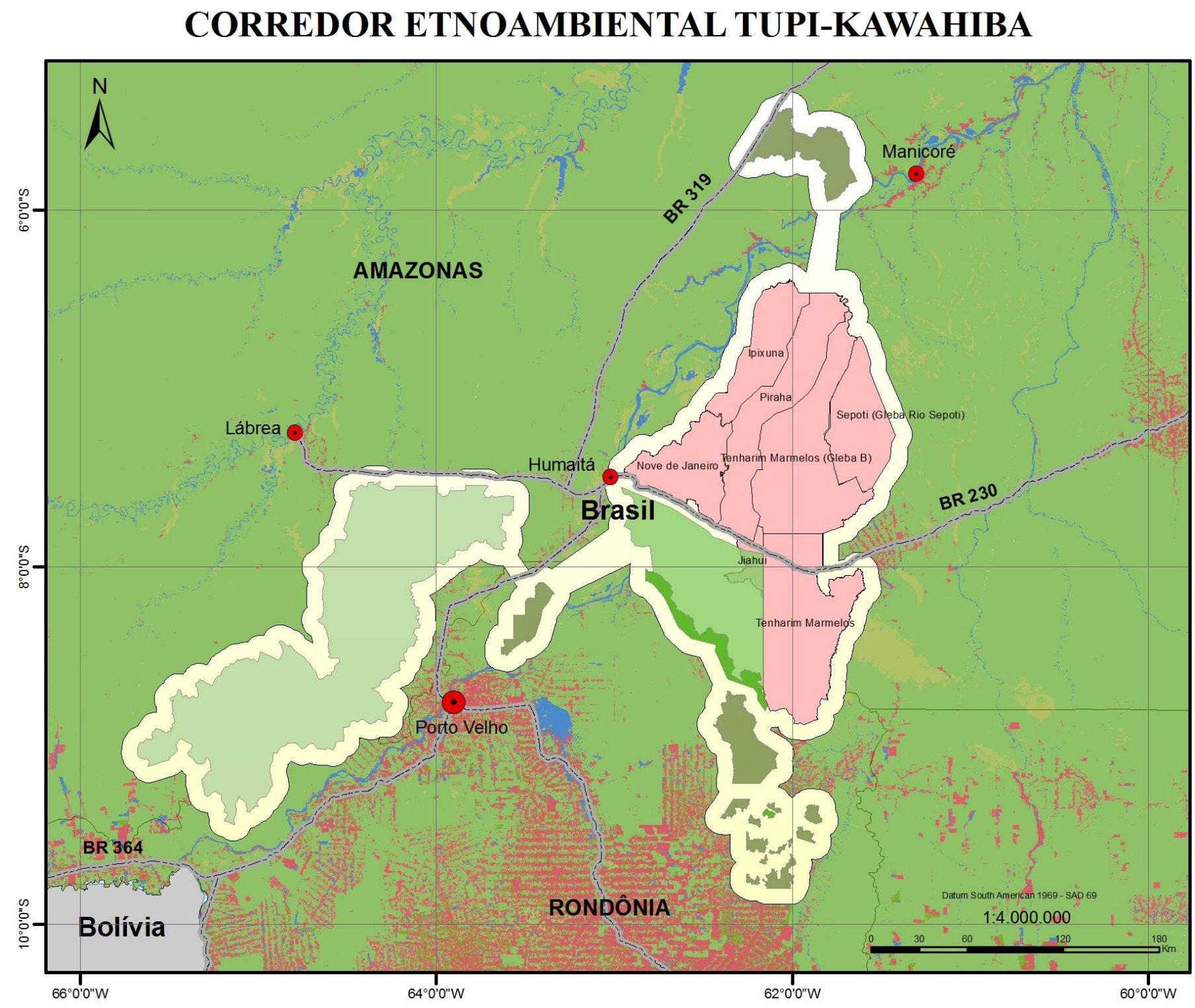

\section{Ecamals \\ EQUIPE DE CONSERVACȦO DA AMAZOONIA}
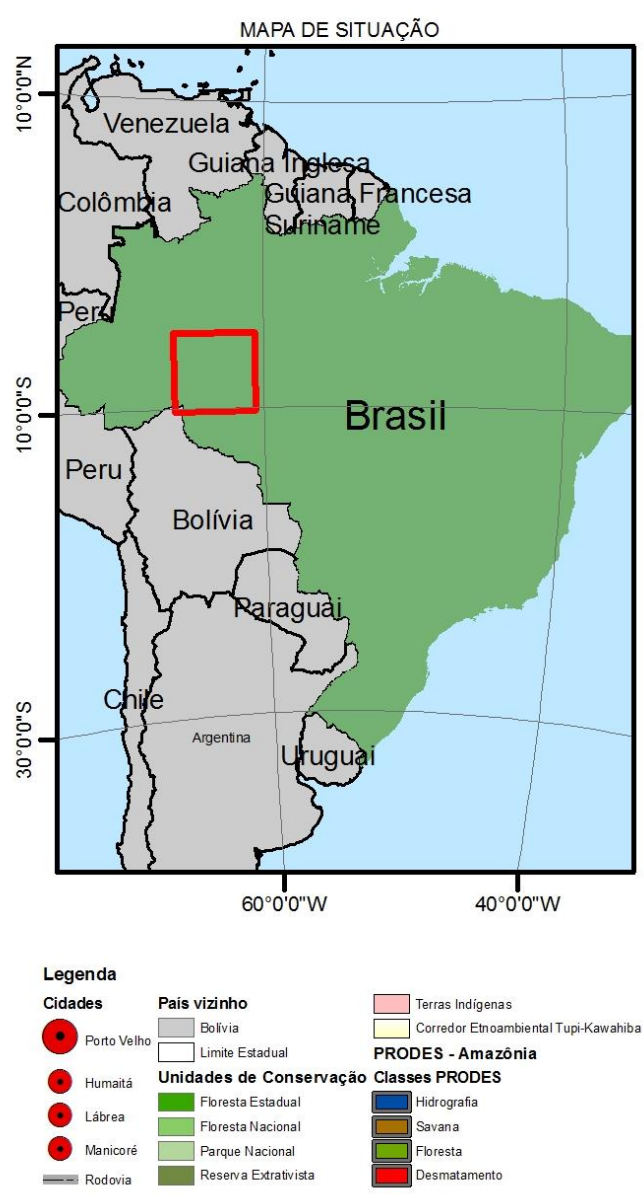

Figura 4 - Mapa do Corredor Etnoambiental Tupi-Kagawahiba, Fonte: ECAM. 
A TI Jiahui possui aproximadamente 48000 ha e em suas áreas fronteiriças se encontram as TIs dos Pirahã (ao norte) e dos Tenharim (a leste). A comunidade é formada por 77 pessoas (APIJ, 2010), desse total, a maioria (59 pessoas) vive na aldeia Ju'i (7 $53^{\circ} 44,282^{\prime}$ S 62 $2^{\circ} 10^{\prime} 43,673$ ” W), e 18 pessoas vivem na aldeia Kawari (7 $51^{\circ}$ ' 11, 469” S 62 ${ }^{\circ} 16^{\prime} 11,805$ ' W). O principal meio de acesso à TI é pela rodovia Transamazônica. O trajeto saindo de Porto Velho (RO), é feito pela BR-319 até o município de Humaitá (AM), de lá o trecho é descontinuado pelo rio Madeira, sendo necessária a travessia de balsa, após a qual se dá o acesso a BR-230 que dá acesso direto às aldeias do povo Jiahui.

O território Jiahui, assim como tantos outros na Amazônia brasileira, apresenta uma dinâmica marcada pelas intervenções das políticas de integração nacional, por processos migratórios próprios da cultura indígena e também pelo uso e ocupação das terras por não indígenas. Para compreender a dinâmica territorial desta TI é interessante observar alguns fatores relevantes da ocupação histórica, são eles: a influência da mineração, a delimitação das terras para uso do exército, a criação da Floresta Nacional de Humaitá, e os processos migratórios do povo Kagwahiva.

Os Jiahui possuem sua referência histórica a partir do processo migratório ocorrido em período posterior a 1750 na região do curso superior do Rio Juruena, no Mato Grosso. A migração ocorreu em função da frente mineradora e também pelos conflitos vividos com seus inimigos tradicionais, os Munduruku. O Relatório de Identificação e Delimitação da Terra Indígena, realizado pela FUNAI, reitera que os Jiahui já se movimentavam na região por conflitos entre etnias e também pelas pressões externas, como a mineração por exemplo. Assim, os Jiahui ocuparam o Alto Tapajós, de onde, acuados pelos Munduruku, migraram para a região do curso médio do Rio Madeira, que se tornou referência de território tradicional para a comunidade. Na década de 1970 foram expulsos de lá e o grupo praticamente se dissolveu devido a conflitos com grupos indígenas vizinhos (FUNAI, 2000).

Com o quase desaparecimento dos Jiahui, os remanescentes aliaram-se aos Tenharim e foram viver na aldeia do grupo nas proximidades da Transamazônica . Casaram-se e tiveram filhos, mas nunca foram totalmente absorvidos pelos Tenharim. Então, transferiram-se para o limite leste da terra Tenharim e de lá iniciaram incursões no território tradicional, que estava ocupado por fazendas. Tais incursões inicialmente 
se resumiam a caça e coleta, mas posteriormente se apropriaram do território construindo as aldeias e plantando roças (ECAM, 2013).

Como os Jiahui passaram um tempo vivendo com os Tenharim, suas terras tradicionais passaram a ser ocupadas por fazendeiros que foram abrindo pastagens e criando gado, além de retirar ilegalmente parte da madeira. Estes fazendeiros chegaram na região, antes da demarcação da terra indígena, recebendo incentivo do Instituto Brasileiro de Colonização de Reforma Agrária - INCRA, por meio de um assentamento que distribuiu terras a diversos indivíduos. Os lotes eram de 100 hectares, mas com o passar do tempo, muitas terras foram abandonadas e/ou vendidas para vizinhos e desta maneira, alguns poucos passaram a ter uma quantidade de terras maior (FUNAI, 2000).

Em 22 de março de 1988, o então presidente da república José Sarney publicou o Decreto número 95.859 definindo as glebas Boa Esperança e Pupunhas para uso especial do Exército, com 468.790 ha criando a Gleba Militar de Humaitá. De acordo com o decreto, a área destinada ao uso do exército limitava-se com a reserva indígena dos Tenharim (FUNAI-MJ/MMA, 1999/2000). Mas, em 1998 foi criada na mesma superfície da área de uso especial do exército, por meio do decreto 2.485 de 02 de fevereiro de 1998, a FLONA de Humaitá, fato que torna evidente as intervenções do Estado, via criação de áreas especiais, em detrimento da ocupação histórica indígena.

O território Jiahui só foi reconhecido pelo governo, através de delimitação oficial, em 2004. Desse modo, as intervenções do Estado na região se deram por meio de políticas públicas espaciais que no primeiro momento representaram uma tendência militarista de controle do território, mas que se transformaram em seguida na defesa de um discurso conservacionista através da criação de uma UC e só depois veio o reconhecimento da cultura tradicional da qual depende da estrutura do território tradicionalmente ocupado.

\section{i) Caracterização Ambiental da TI Jiahui}

O clima na região da terra indígena Jiahui se caracteriza como tropical chuvoso do tipo Am-Tropical de Monção, que apresenta breve estação seca e chuvas intensas durante todo o ano (Köppen, 1948). As temperaturas na região variam de $20,8{ }^{\circ} \mathrm{C}$ até $34,6^{\circ} \mathrm{C}$, sendo a mais alta no mês de setembro e a mais baixa no mês de julho. $\mathrm{O}$ mês 
mais chuvoso, de acordo com o INMET, foi o de fevereiro com precipitação média de 457,9 mm, e o período de seca no mês de setembro com precipitação de 4,2 $\mathrm{mm}$ (INMET, 2010).

A vegetação da terra indígena é caracterizada como Floresta Ombrófila Densa, Floresta Ombrófila Aberta e Savana Florestada. A Floresta Ombrófila Densa tem como principais características as altas temperaturas e o alto índice de precipitação bem distribuído durante o ano, além disso, as folhas das árvores são geralmente largas e estão sempre verdes. Enquanto na Floresta Ombrófila Aberta é considerada uma área de transição entre a floresta amazônica e Savana, tem como principais características o maior espaçamento entre as árvores e um período de seca no ano. A Savana Florestada, conhecida também como Cerradão, é caracterizada por árvores de até 15 metros de altura e ocorrem em áreas com estações de seca e chuva definidas.

Quanto ao tipo de solo, na terra indígena Jiahui são encontrados dois tipos predominantes: Argissolo Vermelho-Amarelo e Latossolo Amarelo. O Argissolo Vermelho-Amarelo é um solo com profundidade variável, mas em geral são pouco profundos e os solos desta classe têm como característica marcante um aumento de argila do horizonte superficial A para o subsuperficial B com uma grande diferenciação de cor. O Latossolo Amarelo é um solo profundo, de coloração amarelada, perfis muito homogêneos, com boa drenagem e baixa fertilidade natural em sua maioria (Campos \& Machado, 2011).

O relevo na região da terra indígena é basicamente plano, possuindo alguns pontos de maior elevação do terreno, que variam de 100 a 250 metros.

Com relação aos recursos hídricos, a terra indígena Jiahui está localizada na Bacia do Rio Amazonas, que possui várias sub-bacias entre elas a do Rio Maici que, afluente do rio Marmelos, deságua no Madeira. O rio Maici ou Mparanã Pykahu, como é chamado na língua Kagwahiva, localiza-se a oeste da Terra Indígena Jiahui entrando no território apenas na parte sul da terra. Tanto o rio Maici como o rio Marmelos são caracterizados como cursos de águas pretas e com uma rica biodiversidade (Machado,2000). Na TI Jiahui existem, ainda, sete cursos d'água de principal uso da comunidade, são os igarapés Tauií Mirim, Sapatão, Armando, do Rei, Palha Branca, da Fazenda e Amazônia. Encontram-se também quatro lagos dentro dos limites da terra indígena, sendo três na área de sobreposição com a FLONA e um mais próximo à rodovia, entre as aldeias (Campos \& Machado, 2011). 


\section{i) Projetos desenvolvidos e Estruturas de Gestão - TI Jiahui e FLONA de Humaitá}

A comunidade, representada pela Associação do Povo Jiahui (APIJ) e suas lideranças, se mobilizou na busca de parcerias para o desenvolvimento de uma série de projetos que vem sendo realizados desde 2010. Os estudos têm o objetivo de produzir conhecimento sobre a terra, valorizar a cultura indígena e planejar o uso dos recursos naturais do território. Os trabalhos desenvolvidos: Etnomapeamento (Mapa Cultural), Etnozoneamento, Diagnóstico Etnoambiental Participativo, Plano de Proteção Territorial e Plano de Gestão Territorial e Ambiental encontram embasamento legal e de políticas públicas nas diretrizes e objetivos da PNGATI como instrumentos de conservação e gestão ambiental e territorial.

Os estudos e projetos desenvolvidos na FLONA de Humaitá ainda não são informações de domínio público, pois os mesmos encontram-se em fase de planejamento, com previsão para apresentação no segundo semestre de 2015 (o que ainda não ocorreu até abril de 2016). O que existe até o momento é um acordo de gestão elaborado de forma conjunta entre os moradores da FLONA, população indígena, conselho consultivo e órgão gestor da UC Instituto Chico Mendes de Conservação da Biodiversidade (ICMBio). Existem também alguns estudos de subsídio a elaboração do Plano de Manejo (PM). Segundo legislação vigente, a participação da comunidade na gestão desse tipo de área protegida se dá através do conselho consultivo cuja função é "tratar de temas afetos à Unidade de Conservação, subsidiar a tomada de decisão do órgão gestor e apoiar as ações de implementação da unidade no que couber" (BRASIL, 2014). 


\section{CAPÍTULO I - CONCEITOS FUNDAMENTAIS, RECORTES CONCEITUAL E TEMÁTICO}

O primeiro capítulo apresenta a fundamentação teórica e a construção do objeto de pesquisa. A partir de uma reflexão sobre sociedade e natureza, no contexto da Geografia, entende-se que a perspectiva socioambiental é fundamental à abordagem do tema escolhido: gestão de territórios protegidos em sobreposição na Amazônia brasileira. A temática relacionada envolve as dimensões política e ambiental em escalas e temas diversos. Nisto consiste o desafio de se delimitar um objeto de pesquisa, pelo viés geográfico, diante de tamanha complexidade. É preciso considerar as relações entre tais dimensões, ecalas e temas. O que exige uma leitura integrada.

O Território Usado foi a categoria de análise utilizada para buscar a referida integração. O caráter social que pauta o conceito evidencia a importância do uso na configuração territorial. Assim, chegou-se ao elemento chave para delimitação do objeto de pesquisa que é a relação entre a gestão e o uso desses Territórios em sobreposição. Estes são os principais pontos do primeiro capítulo. A proposta é apresentar os preceitos teóricos que embasam a pesquisa em seus aspectos metodológicos, teóricos e empíricos. Espera-se também que esta primeira parte do trabalho seja o norte dos demais capítulos.

\subsection{RELAÇÃO SOCIEDADE/NATUREZA}

A gestão de Territórios Protegidos é um tema transversal às linhas de pesquisa da Geografia, pois envolve elementos da relação sociedade e natureza situados na dimensão política, cultural e ambiental. Na abordagem da problemática que envolve as sobreposições entre tais territórios, esses elementos se apresentam como componentes de um mesmo processo de configuração e transformação do espaço geográfico. Para compreender tal processo a partir de uma abordagem geográfica é necessário ampliar o campo de investigação, com enfoque que abarque ao menos o político e o ambiental nas suas implicações espaciais.

No âmbito das pesquisas geográficas os fenômenos políticos e naturais foram, e ainda são, abordados em linhas de pesquisa diferentes que, por vezes, não dialogam. De um lado, a dita Geografia Física se ocupa dos fenômenos geológicos, químicos e biológicos dos sistemas naturais, do outro a dita Geografia Humana investiga os processos sociais que envolvem modo de produção, geopolítica, representações sociais, 
etc. Esse modo de compreender os fenômenos e estudá-los separadamente negligencia a conexão entre o social e o ambiental, que é um fator chave do próprio espaço geográfico.

Em detrimento dessa perspectiva dicotômica, a chamada 'Crise Ambiental' ${ }^{10}$ abre oportunidades de estudos mais integrados. Quando parte da sociedade ${ }^{11}$ percebe os prejuízos causados pela degradação dos sistemas naturais e começa a investigar os sistemas sociais, mais especificamente os modos de vida, em busca de soluções para o problema. Neste contexto, o papel da ciência se torna fundamental para se encontrar respostas. Assim, as questões socioambientais - considerando neste termo as interações entre sociedades e destas com a natureza - se tornam objeto de estudo para a comunidade científica. No campo da Geografia, uma nova corrente do pensamento denominada Geografia Socioambiental surge com o objetivo de investigar essa problemática, e consequentemente construir uma Geografia integrada que, a meu ver, é a única Geografia possível.

Na perspectiva da Geografia Socioambiental o intuito é

conceber o natural e o social como elementos de um único processo, onde o conhecimento na Geografia deixa de ser físico ou humano para se tornar geográfico. É necessário compreender os problemas socioambientais na lógica da complexidade. Estes problemas são sistemas complexos, nos quais interferem processos de diferentes racionalidades, ordens de materialidade e escalas espaçotemporais. (BÊZ, M \& FIGUEIREIDO, L.C, 2011, p. 64)

Com base nas premissas da Geografia Socioambiental, a concepção da relação entre sociedade e natureza adotada nesta pesquisa se caracteriza principalmente pela interdependência entre o político e o ambiental, materializada no espaço a partir dos múltiplos territórios que institui. Seguindo tal pressuposto para análise da referida temática, observam-se aqui alguns recortes e perspectivas nos quais os aspectos socioambientais encontram-se imbricados e ativos em marcos espaciais e territoriais.

A princípio observa-se os diversos discursos e intencionalidades que ao longo do tempo (re)significaram a concepção de natureza e criaram um movimento ambientalista global. Em seguida o processo histórico do modo de vida dos povos originários do Brasil em suas terras mediado pelo poder público. E por fim, a estrutura de Políticas Públicas que possibilitam a criação, o reconhecimento e a continuidade de territórios

\footnotetext{
${ }^{10}$ Conforme abordado em Santos (1995, p.695).

${ }^{11}$ Parcela da sociedade organizada em instituições cujas ações alcançam escala global.
} 
que materializam a ideia de proteção/conservação da natureza e o processo de territorialização indígena (Figura5).

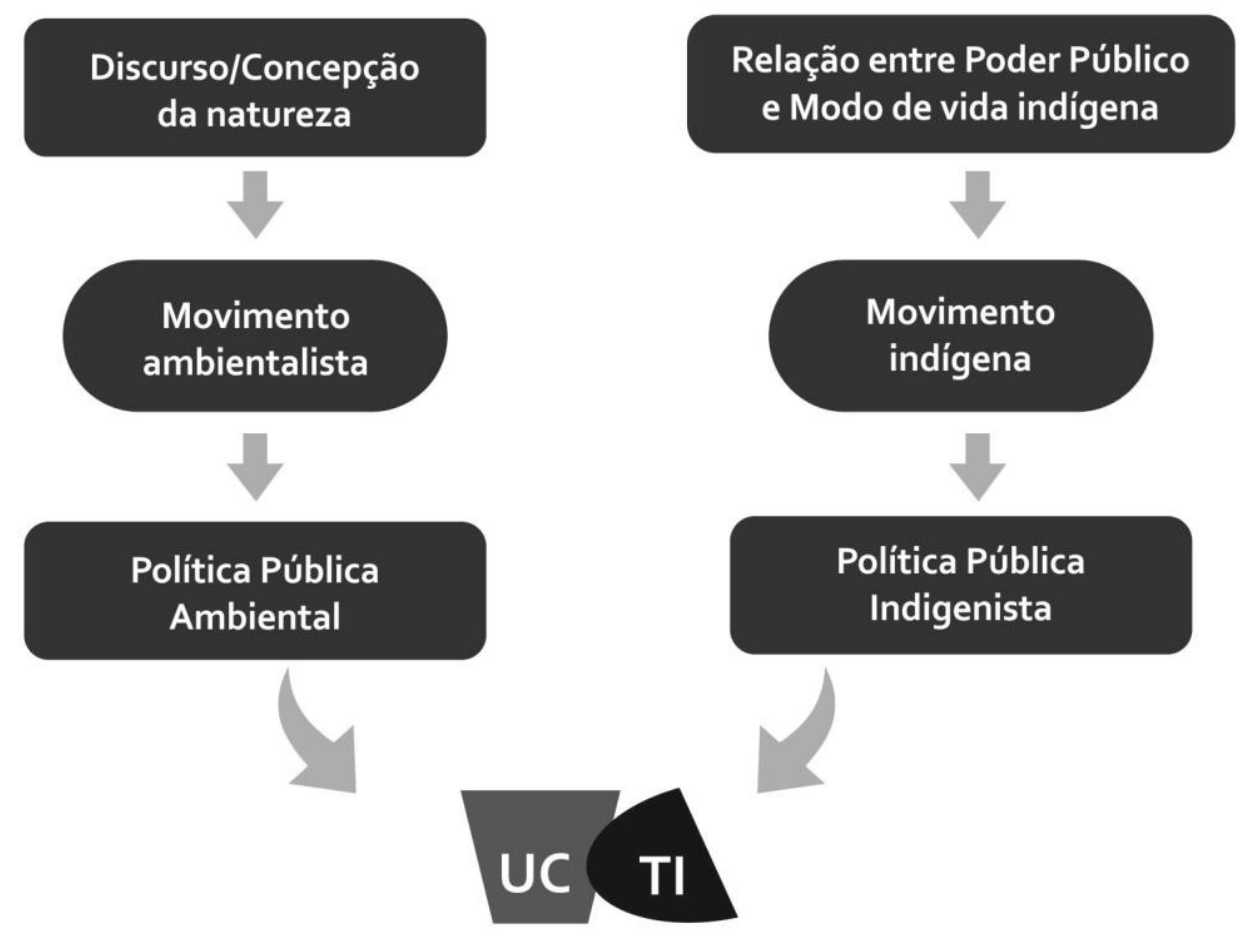

Figura 5 - Processo histórico e espacial de formação dos territórios protegidos

Para a sociedade atual, pós década de 1970 mais especificamente, a preocupação com o ambiente deixou de ser uma questão de interesse apenas de grupos ambientalistas. Atualmente o tema se tornou interesse comum entre diversos setores da sociedade, dentre os quais: Estado, academia, setor privado e terceiro setor. Nesse sentido, o paradigma ambiental, centrado nos conceitos conservacionistas e preservacionistas, atingiu a escala global. Porém, é importante ressaltar que trata-se de um cenário recente. Mesmo o surgimento do ambientalismo, enquanto movimento social organizado e presente na esfera política planetária, deu-se há menos de 50 anos com a Confederação das Nações Unidas sobre Meio Ambiente Humano que ocorreu em Estocolmo no ano de 1972.

A partir dessa conferência, que se tornou um marco para o debate mundial sobre a questão ambiental, os movimentos sociais ligados à problemática ambiental se estabeleceram. Neste contexto, as noções de preservação e conservação foram se desenvolvendo e ganhando escala em vários setores da sociedade. O termo conservação vem de uma perspectiva na qual o uso dos recursos naturais por meio de um manejo 
sustentável é a chave de uma integração harmônica entre sociedade e natureza. Já a preservação vem de uma visão embasada na concepção de uma natureza intocada, separada da humanidade, isenta da presença humana. A criação dos Parques Nacionais, como Yelowstone e Itatiaia, por exemplo, foi fortemente influenciada por essa ideia de preservação.

Nesses termos - preservação e conservação - encontram-se as matrizes do que é discutido em toda a amplitude que a questão ambiental alcançou. Pelo viés conservacionista, enfoque desta pesquisa, um dos principais focos de debate é o Desenvolvimento Sustentável. O termo se destaca frequentemente pela importância econômica da natureza conservada, daí também o termo recurso natural onde os sistemas naturais e seus elementos se inserem nos processos produtivos. Entretanto, alguns autores defendem que não se trata apenas da valoração financeira e de produção, mas também da social e ambiental. A definição mais recorrente para o termo, conforme aponta Sachs (2009, p.8) define-se por três elementos ou o "trevo clássico com as três folhas: eficiência econômica, conservação ambiental e equidade social" e ainda há aqueles que acrescentam outras pétalas, tais como: político-institucional, cultural, espacial, tecnológica, etc. (SACHS, I. 2009 p.8).

O debate sobre Desenvolvimento Sustentável apresenta tópicos polêmicos que se tornaram alvos de questionamentos, como equidade social, por exemplo. A reflexão crítica parte das pesquisadoras e pesquisadores que propõem o debate, os quais reconhecem as contradições inerentes ao conceito, sobretudo quando contextualizado na realidade do sistema capitalista. Nesse sentido, quando Sachs (2009) afirma que "a eficiência econômica só tem valor se conservar a natureza e produzir equidade social", reconhece também que, na prática, trata-se de processos distintos. $\mathrm{O}$ autor faz duas observações relativas a tal distinção,

primeiro: o crescimento econômico, em conformidade com o padrão de consumo vigente no mundo desenvolvido, provoca destruição ambiental e gradativamente se torna inviável [...] Segundo: não há equidade social em uma economia de mercado. (SACHS, I. 2009, p.11)

De fato, quando a questão ambiental ganha escala nos diversos setores da sociedade, recai, inevitavelmente, sobre os processos do atual sistema econômico que é contraditório e desigual em sua essência. Trata-se de um impasse. Por um lado, admite- 
se que é impossível realizar o debate sobre Desenvolvimento Sustentável fora do sistema econômico no qual vivemos, mas por outro, tornou-se evidente que tal conceito, conforme o referido trevo de três folhas é inviável nos moldes do capitalismo. Essa é também a crítica existente no âmbito da Geografia, difundida, em especial, pelas geógrafas e geógrafos de filiação marxista.

Neste contexto de reflexões críticas, os conceitos de Meio Ambiente e Desenvolvimento Sustentável são tratados por Souza (2009) como "metáforas do capitalismo". O argumento da autora para tal afirmação consiste na impossibilidade de existir sustentabilidade num sistema econômico que necessita da insustentabilidade para se manter. A referida autora também afirma que não se tem, nos termos da Geografia, a consistência teórica necessária para a abordagem da temática. Para ela, nesta ciência tratamos de outros conceitos como "meio natural, meio geográfico, meio técnico e meio técnico científico e informacional" (SOUZA, 2009, p. 101). De acordo com tal reflexão existe, portanto, um problema relacionado à própria existência da questão ambiental centrada nos conceitos de Meio Ambiente e Desenvolvimento Sustentável e outro epistemológico, para abordagem da temática na Geografia.

As críticas às formas de abordagem da questão ambiental, em especial do Desenvolvimento Sustentável, são pertinentes e contribuem para o processo de amadurecimento da abordagem científica do tema. Isso porque a produção de conhecimento realizada pelo método científico, sobretudo quando se trata da abordagem de um tema tão complexo e recente nas Ciências Humanas, não se faz a partir de um pensamento único e nem tão pouco embasado em uma única matriz filosófica e/ou metodológica. É preciso estabelecer um diálogo que considere diversas perspectivas e discursos nas bases disciplinares e entre as disciplinas (transdisciplinaridade). Santos (1995) reitera a importância da abordagem do tema e da reflexão epistemológica necessária para fazê-lo, quando diz que:

a denominada crise ambiental a que hoje assistimos [...] deve suscitar uma revisão das teorias e práticas das diversas disciplinas na medida em que demanda uma análise compreensiva, totalizante, uma análise para a qual as pessoas vindas de horizontes diversos e que trabalhem com a realidade presente, tenham o seu passo acertado através do mundo, através de um legítimo trabalho interdisciplinar. (SANTOS, M. 1995, p.695). 
Considerando a diversidade de perspectivas sobre a questão ambiental, vale aqui uma breve interlocução sobre uma crítica convergente na visão do economista Sachs (2009) e da geógrafa Souza (2009). Em meio as suas reflexões - sendo o primeiro pesquisador dedicado ao tema e a segunda partindo de uma reflexão mais pontual - os referidos autores observaram o mesmo aspecto acerca do Desenvolvimento Sustentável: a contradição inerente à sustentabilidade num sistema capitalista. Diante dessa observação, que, aliás, é a mais recorrente, esses autores propõem um debate e apresentam proposições diferentes, e relevantes, para se lidar com o tema.

Quando Souza (2009) afirma que os conceitos de Meio Ambiente e Desenvolvimento Sustentável são metáforas, ou conceitos vazios, ela demonstra preocupação com o contexto político da construção de um discurso pautado nos referidos conceitos. Mas, o principal argumento que a autora utiliza para tal afirmação a impossibilidade de existir o sustentável no capitalismo - é justamente um dos caminhos que nos leva à reflexão sobre a correspondência de tais conceitos com a realidade, o que os retira da condição de conceito vazio. Nas contradições de se pensar sustentabilidade no sistema capitalista (por essência, insustentável), está uma das oportunidades de se trazer esses conceitos para um debate científico na perspectiva geográfica, nas suas várias possibilidades de recorte ${ }^{12}$.

A referida autora sugere também que a Geografia não possui bases teóricas e metodológicas para abordagem da temática que envolve os referidos conceitos e enfatiza a necessidade de acompanhamento epistemológico. Nesse sentido, é importante lembrar que se trata de uma ciência com histórico construído a partir de estudos voltados para a relação sociedade e natureza. Obviamente tal construção foi realizada a partir de conceitos e nomenclaturas de cada tempo-espaço. O que certamente não exclui a necessidade de um acompanhamento espistemológico.

Nesse sentido, cabe à Geografia, ao se inserir neste campo de investigação e debate, contextualizar os termos ou "bem precisar o objeto de estudo" como diz Santos (1995), a partir dos recortes espacial e territorial. Desse modo, se pode afirmar que não se trata de metáforas, pois existe uma correspondência direta entre a reflexão teórica que dá nome aos fenômenos (meio ambiente, ambiente, natureza, meio geográfico, etc.) e a realidade que consiste em dinâmicas socioespaciais concretas. A exemplo disso, se pode

\footnotetext{
${ }^{12}$ É importante ressaltar que as contradições contidas no conceito de Desenvolvimento Sustentável no sistema capitalista é uma possibilidade de debate que evidencia bem a relação sociedade e natureza. Mas não é o enfoque principal da pesquisa, trata-se apenas de uma discussão relacionada ao tema e que devido à sua relevância e inserção, mereceu ser citada.
} 
citar as políticas públicas ambientais que viabilizaram a criação de 320 UCs federais distribuídas em todos os biomas brasileiros, o que representa aproximadamente $20 \%$ do território nacional quando somadas às estaduais e municipais (MMA).

Em contrapartida à reflexão crítica sobre a elaboração e o uso do conceito de Desenvolvimento Sustentável, por serem criados a partir de movimentos políticos globais, Souza (2009) aponta uma proposta para se estruturar as bases de uma metodologia. Segundo a autora é possível fazê-lo de diferentes maneiras, sobretudo a partir das técnicas de mapeamento integradas aos processos históricos da formação socioespacial.

Hoje se dispõe de Sistemas de Informações Geograficas que permitem uma visão empírica integrada do funcionamento do território e a sua rápida regionalização. Essa praticidade fornecida pela informática precisa ser casada com a compreensão dos processos históricos da formação socioespacial (SOUZA, M.A. 2009, p.113).

A proposta de Souza (2009) para a abordagem da questão ambiental na Geografia está centrada na utilização das técnicas de espacialização (cartografia, SIG, etc.) como fator fundamental para uma visão integrada, que ela chama de socioespacial. Para ela, a perspectiva espacial dos territórios (aqui trabalhada nas transformações territoriais) pode ser a ligação entre a dinâmica empírica e a formulação e utilização dos conceitos. Assim, a discussão sobre a formulação dos conceitos é de extrema relevância. É preciso contextualiza-los, elegendo nomenclaturas que facilitem o diálogo com o mundo real, com o cenário político e com as demais ciências que se voltam para o Ambiente e para o Desenvolvimento Sustentável.

Sachs (2009) concorda com a referida autora sobre as contradições que implicam se pensar e debater sobre Desenvolvimento Sustentável, mas defende a necessidade do conceito por dois motivos: primeiro, é um instrumento para avaliar o passado; segundo, é necessário um marco conceitual para a construção de novos paradigmas. O referido autor pensa a questão a partir de uma visão das lógicas globais (mundo globalizado) em relação às locais (dinâmicas territoriais). Para ele,

a visão do desenvolvimento no futuro é de um desenvolvimento participativo e negociado. Ou seja, deve-se organizar o debate em todos os níveis, desde o desenvolvimento local, por exemplo. Pode-se começar por um fórum de desenvolvimento local, mais tarde esse fórum se transforma num conselho consultivo que com o tempo cresce para ser um conselho deliberativo [...] Essa pactuação pode tomar 
várias formas, e a seguir vem a questão da pactuação entre o nível local e o nível federal (SACHS, I. 2009 p.28-29).

E complementa:

é dentro desse movimento que devemos definir estratégias. Estratégias certamente nacionais, para começo de conversa. Penso que a globalização, em vez de reduzir, realça a importância das estratégias nacionais. Porque é muito grande a vulnerabilidade dos países em relação aos processos de globalização, e se não há uma estratégia que procure, por um lado proteger e, por outro lado aproveitar as janelas de oportunidade, não se pode trabalhar. Nós não estamos num mundo globalizado, estamos num mundo em que ocorrem processos de reglobalização [...] (SACHS, I. 2009 p.30).

Dos tópicos concernentes à questão ambiental, o Desenvolvimento Sustentável tem sido pauta recorrente nos espaços de debate. O que os diversos setores da sociedade articulam sobre o tema interfere direta e/ou indiretamente nas políticas públicas resultantes desses diálogos. É neste aspecto que o tema se torna tangente ao recorte analítico aqui proposto. Ao atingir a esfera das políticas públicas a complexidade da questão ambiental, que abarca diversas propostas de Desenvolvimento Sustentável, passa a integrar os dispositivos de gestão estatal. Assim, a gestão de território protegidos sobrepostos está fortemente influenciada pelas concepções e visões sobre a natureza, principalmente à sustentabilidade. Nesse sentido, as UCs de uso sustentável passam a integrar um modelo de desenvolvimento que se fundamenta na ideia de sustentabilidade.

Essa dinâmica de reflexão da sociedade a respeito da problemática ambiental alcançou uma escala global ao mesmo tempo em que as políticas públicas ambientais foram se estruturando no Brasil (Figura 6). A partir de tal estrutura que delimita territórios de proteção bem como suas normas de uso, é possível observar, em parte, a consolidação de toda essa reflexão. 
Espaços

Globais de

debate do

movimento

ambientalista

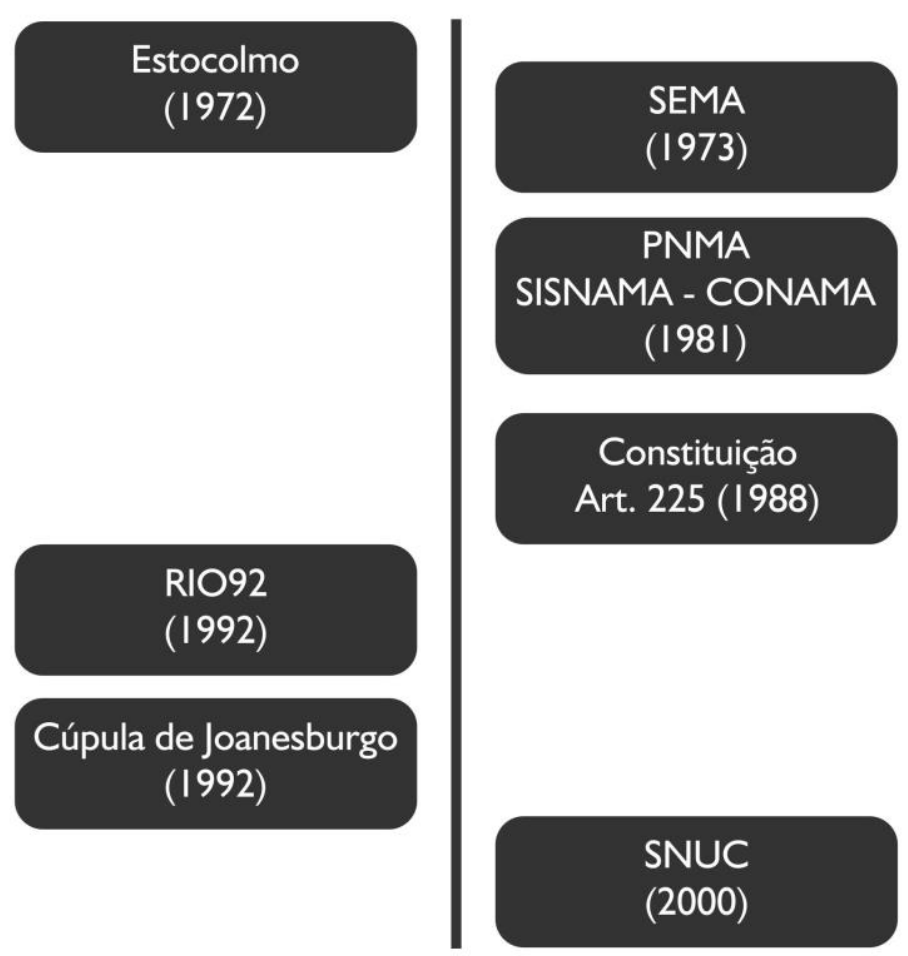

Políticas

públicas

ambientais

no Brasil

$(2000)$

Figura 6 - Linha do tempo (reduzida) - Eventos ambientalistas e as políticas públicas ambientais no Brasil. Fonte: Funag, 2006 (adaptado pela autora).

Nos primeiros anos que se seguiram à conferência de Estocolmo, o movimento ambientalista ganhou escala e se consolidou por meio da criação de instituições globais, como o Programa das Nações Unidas para o Meio Ambiente (PNUMA), e pela influência nas políticas públicas de cada país. No Brasil a repercussão de Estocolmo respaldou a pressão de setores da comunidade acadêmica e de ONGs para a criação de um setor ambiental no governo. Isso resultou, em 1973, na criação do primeiro órgão federal com autoridade para tratar das questões ambientais, a Secretaria Especial de Meio Ambiente (Sema).

Entretanto, a essa altura o movimento ambientalista globalizado, ainda não abordava a questão ambiental com a devida integração com as organizações sociais. Os projetos e ações oriundos desse movimento ainda centralizavam a concepção de preservação da natureza, deixando como segundo plano ou suporte, as organizações sociais. Essa concepção começa a se transformar em 1992, com a Conferência das Nações Unidas sobre Meio Ambiente e Desenvolvimento (ECO92) que ocorreu no Rio de Janeiro. 
Os resultados das discussões realizadas durante este evento representaram um passo na direção de uma abordagem socioambiental. Essa perspectiva ganha visibilidade e certa consistência no contexto da Agenda 21, principal resultado da Conferência. O documento contempla em sua terceira sessão o "fortalecimento dos grupos sociais (mulheres, crianças, indígenas, ONGs, etc.) na implementação do objetivo do Desenvolvimento Sustentável”, antes disso os indígenas, por exemplo, não haviam sido citados de forma direta no debate ambiental (Funag, 2006).

Diante do exposto, pode-se afirmar que a questão ambiental é, na verdade, uma questão socioambiental, cuja resolução pressupõe estratégias baseadas na concepção integrada entre sociedade e natureza. Os territórios tradicionais, em especial os indígenas, são um ponto estratégico para se alcançar tal integração, da qual depende o avanço no âmbito da referida problemática. Não é possível realizar o planejamento de ações voltadas para conter a degradação da natureza sem mencionar a importância da biodiversidade $^{13}$ nesses territórios. Assim, a questão indígena deve ter representatividade nos espaços criados pelo movimento ambiental globalizado, de modo que a importância das TIs para conter o desmatamento, preservar recursos hídricos, etc. seja amplamente reconhecida, alcançando o apoio da comunidade internacional.

Atualmente, a inclusão da questão indígena no debate ambiental ainda é incipiente e por vezes meramente simbólica. A exemplo disso se pode citar a pauta do último grande evento da Organização das Nações Unidas (ONU) realizado em 2015 para discutir as mudanças climáticas: a Conferência das Nações Unidas sobre Mudanças Climáticas (COP21). A agenda do evento apresentou poucas propostas que abordam o potencial de preservação, conservação e mitigação de impactos das TIs. Segundo relatório da Rights and Resources Initiative (RRI) poucos dos governos integrantes da conferência mencionaram povos indígenas em suas propostas de conservação ou políticas climáticas. Segundo a pesquisa, 26 dos 47 países analisados não fizeram nenhuma referência à gestão de TIs em suas propostas.

A baixa representatividade da questão indígena, e das populações tradicionais, nos espaços de debate que se propõem a encontrar soluções para a crise ambiental é incoerente e injusta em vários aspectos. Mas restringindo-se apenas ao problema do desmatamento já é possível se ter noção das proporções de tal incoerência. A efetividade de TIs no controle do desmatamento - um dos grandes 'gargalos' dos

\footnotetext{
${ }^{13}$ Considerando o modo de vida indígena como parte da biodiversade.
} 
impactos socioambientais - foi analisada por meio de uma pesquisa intitulada Rethinking Tropical Forest Conservation: perils in the parks ${ }^{14}$ publicada no períodico Conservation Biology. A pesquisa mostrou que as TIs são mais eficientes, ou tão eficientes quanto, os Parques Nacionais - UCs de proteção integral - em conter o desmatamento. Os autores atribuem a conservação da cobertura vegetal nessas terras à presença de populações tradicionais que atuam como agentes políticos no embate contra a exploração ilegal de madeira e ainda desenvolvem técnicas de manejo tradicionais adaptadas ao equilíbrio ecossistêmico.

No entanto, para que as TIs cumpram esse papel conservacionista, não basta apenas o fato de terem a terra tradicional demarcada e uma identidade indígena. É necessário ter condições de gestão dos recursos naturais e de amenizar os impactos negativos. O nível de conservação encontrado nessas terras está relacionado às condições de uso que as comunidades têm, o que envolve: impacto de densidade demográfica, destino de resíduos, técnicas de manejo para agricultura, alternativas econômicas, fortalecimento de saberes tradicionais, etc. Ou seja, assuntos que dizem respeito à gestão dos territórios que, não por acaso, são pontos fundamentais das discussões do movimento ambientalista. Pore isso a importância de buscar o lugar das comunidades indígenas em tais espaços (POZZOBON, J. \& LIMA,D. 2005).

Mas é importânte ressaltar que para se trabalhar tais demandas de uso sustentável no contexto de povos e terras indígenas, é preciso se atentar para as especificidades étnicas. Os povos indígenas possuem uma relação intrínseca com suas terras da qual depende sua sobrevivência e o fortalecimento de suas manifestações culturais. Essa relação representa uma dinâmica socioambiental de interdependência entre organização social e sistemas naturais. Neste contexto, a biodiversidade contida nessas terras deve ser entendida para além dos componentes físicos dos ecossistemas. Conforme propõe Almeida (2003), é necessário considerar em tal conceito, os aspectos culturais das populações que vivenciam tradicionalmente os biomas, integrando espaço e natureza em seus sistemas culturais.

$\mathrm{O}$ respeito às especificidades étnicas e à autonomia indígena no contexto de uso e gestão de seus territórios encontra respaldo nos marcos legais que atualmente estruturam a política indigenista brasileira. Mas tal estrutura, que ao menos do ponto de

\footnotetext{
${ }^{14}$ Repensando a conservação da floresta tropical: perigos nos parques. Schwartzman, S.; Moreira, A.; Nepstad, D. Rethinking conservation of tropical forests: perils in parks. Conservation Biology. 2000. 14: 1351-1357. Doi: 10.1046/j.1523-1739.2000.99329.x.
} 
vista oficial, preza pela autonomia e pela diversidade, é resultado das vicissitudes entre as ações do poder público, direcionadas à dominação do território, e a resistência indígena, realizada por meio da apropriação dos territórios. Neste processo, a questão da terra/território é central tanto para o Estado quanto para os indígenas. Ao observarmos como tal questão é tratada nas Constituições do país, nota-se que desde a primeira Carta Magna a condição de incapacidade foi atribuída aos indígenas, o que colaborou para que a gestão e o controle de suas terras se tornassem atribuição do poder público. Somente em 1988 a Constituição traz o princípio da autonomia desses povos, o qual segue a atual política de gestão de TIs (LOPES, B.D. 2014).

A intervenção do poder público, sob o modo de vida dos povos originários do Brasil ocorre desde o séc. XIX, e foi institucionalizada conforme estruturas políticas delimitadas nos períodos da Colônia, Império e República. Historicamente, as ações destinadas aos indígenas foram centradas na importância de suas terras e na anulação da identidade indígena. Essa perspectiva pode ser constatada a partir dos dispositivos legais que trataram a questão indígena nas constituições brasileiras (Tabela2). A importância da autonomia e da identidade indígena, aliada à proteção das terras, só foi oficializada na Constituição de 1988 (LOPES, D.B. 20014). 
Quadro Síntese sobre a abordagem da questão indígena nas Constituições e Legislações complementares.

\begin{tabular}{|c|c|c|c|}
\hline $\begin{array}{l}\text { Marcos Legais } \\
\text { por período }\end{array}$ & $\begin{array}{l}\text { Concepção dos } \\
\text { indígenas }\end{array}$ & Concepção sobre as Terras & Contexto \\
\hline Período Colonial & Índios Amigos ou Bravos. & Aldeamentos criados pela Coroa. & Coroa Portuguesa. \\
\hline $\begin{array}{l}\text { Constituição do } \\
\text { Império do Brasil } \\
\text { (1824) }\end{array}$ & A serem catequisados e civilizados. & $\begin{array}{l}\text { Importante para a consolidação das } \\
\text { fronteiras do império. }\end{array}$ & Foi inserida por meio de um ato adicional em I 834. \\
\hline $\begin{array}{l}\text { Constituição } \\
\text { Republicana } \\
\text { de } 189 \text { I }\end{array}$ & Não foram citadas. & Não foram citadas. & $\begin{array}{l}\text { A comunidade indígena e suas terras não foram } \\
\text { mencionadas, mas o discurso além do documento } \\
\text { oficial era para assimila-los ou eliminá-los. }\end{array}$ \\
\hline $\begin{array}{l}\text { Código Civil de } \\
1916\end{array}$ & \multicolumn{3}{|c|}{ Documento que concebia ao índio a qualificação de 'incapaz'. } \\
\hline $\begin{array}{l}\text { Constituição } \\
\text { de } 1934\end{array}$ & $\begin{array}{l}\text { Condição passageira de silvícolas a } \\
\text { serem incorporados à comunhão } \\
\text { nacional. }\end{array}$ & Garantida a posse sendo vedado aliená-las. & Não há informação. \\
\hline $\begin{array}{l}\text { Constituição de } \\
1937 \text { (Estado Novo) }\end{array}$ & Não foram citadas. & Garantida a posse sendo vedado aliená-las. & Não há informação. \\
\hline $\begin{array}{l}\text { Constituição de } \\
1946\end{array}$ & $\begin{array}{l}\text { Condição passageira de silvícolas } \\
\text { a serem incorporados a comunhão } \\
\text { nacional. }\end{array}$ & Não foram citadas. & Não há informação. \\
\hline $\begin{array}{l}\text { Convenção } 107 \\
\text { OIT } 1957\end{array}$ & \multicolumn{3}{|c|}{$\begin{array}{l}\text { Texto que trata da proteção e integração das populações indígenas e outras populações tribais e semitribais de países independentes - Este texto } \\
\text { influenciou as próximas constituições. }\end{array}$} \\
\hline $\begin{array}{l}\text { Constituição de } \\
1967 \text { (Ditadura } \\
\text { Militar) }\end{array}$ & Mesma perspectiva de assimilação. & $\begin{array}{l}\text { Proteção às terras Incluídas como bens da } \\
\text { União Federal. }\end{array}$ & $\begin{array}{l}\text { Direito ao usufruto exclusivo dos recursos naturais } \\
\text { reconhecido aos indígenas. }\end{array}$ \\
\hline Carta de 1969 & Silvícolas. & Terras inalienáveis. & $\begin{array}{l}\text { Acrescentou a nulidade e a extinção dos efeitos jurídicos } \\
\text { de qualquer natureza para ocupar territórios já } \\
\text { habitados por populações indígenas. }\end{array}$ \\
\hline $\begin{array}{l}\text { Estatuto do } \\
\text { Índio de } 1973\end{array}$ & \multicolumn{3}{|c|}{$\begin{array}{l}\text { Documento que manteve a ideologia Civilizatória, determinou os procedimentos para a demarcação de Tl's e as declarou como abertas as } \\
\text { intervenções por razōes de desenvolvimento e segurança nacional. I/3 da lei trata dos procedimentos relativos às terras }\end{array}$} \\
\hline $\begin{array}{l}\text { Constituição de } \\
1988\end{array}$ & $\begin{array}{l}\text { Comunidade cuja organização } \\
\text { social, costumes, línguas, crenças } \\
\text { e tradições devem ser respeitados. }\end{array}$ & $\begin{array}{l}\text { Direito dos índios que tradicionalmente as } \\
\text { ocupam. Dever da União demarcá-las, } \\
\text { proteger e fazer resepeitar todos os seus } \\
\text { bens. }\end{array}$ & $\begin{array}{l}\text { No processo de elaboração do art. } 23 \text { I da Carta Magna } \\
\text { os indígenas estavam em plena movimentação por sua } \\
\text { autonômia e se inseriram nas discussões da elaboração } \\
\text { do documento. }\end{array}$ \\
\hline $\begin{array}{l}\text { Novo Código } \\
\text { Civil de } 2002\end{array}$ & \multicolumn{3}{|c|}{ Revoga o código de 1916 e determina que a capacidade dos índios será regulada por legislação especial. } \\
\hline $\begin{array}{l}\text { PNGATI } \\
2012\end{array}$ & \multicolumn{3}{|c|}{ Política de Gestão Ambiental e Territorial de Terras Indígenas. } \\
\hline
\end{tabular}


A relação histórica entre os povos indígenas e o poder público desenhou o atual cenário das TIs no Brasil. Desse modo, o espaço de exercício da autonomia e da diversidade cultural indígena possui limites definidos, não conforme suas dinâmicas migratórias e/ou necessidades de produção e subsistência, mas de acordo com as intencionalidades que o poder público assumiu ao longo do tempo. Nesse contexto, os limites das TIs possuem dimensões de tamanho e contexto diferenciados, o que implica em uma realidade diferente para cada comunidade. Implica ainda em problemáticas como a sobreposição com UCs, cuja criação segue a mesma lógica, à dos objetivos governamentais.

Os temas apresentados até aqui revelam uma parte da dinâmica socioambiental, na qual se insere a gestão dos territórios protegidos. Trata-se de temas que transitam entre várias dimensões da sociedade, alguns intangíveis, como a construção de uma visão sobre a natureza, outros tangíveis, como a criação de organizações e legislações específicas. Tal dinâmica se concretiza nas políticas públicas que, por isso, tornam-se um caminho para entender como tais temas estão correlacionados na produção do espaço. Este recorte - feito pelo viés das políticas públicas - é viável pelo fato de que as ações procedentes de tais políticas possibilitam uma análise concreta.

Trata-se também de uma análise da relação sociedade e natureza vista na configuração dos territórios. Vale ressaltar que, neste contexto, não é possível realizar um estudo propositivo apenas pelo viés ambiental, pois envolve também decisões políticas e movimentos sociais. Também não é possível apenas pelo viés social, pois só faz sentido conforme a dinâmica dos sistemas naturais. Desse modo, é necessário um esforço no sentido de realizar uma abordagem socioambiental.

Com o intuito de realizar tal abordagem nesta pesquisa parte-se de duas políticas públicas de escala nacional: a Política Nacional de Gestão Territorial e Ambiental de Terras Indígenas (PNGATI) e o Sistema Nacional de Unidades de Conservação da Natureza (SNUC). As ações oriundas dessas duas políticas desenharam no território nacional um mosaico de territórios protegidos (Figura1) resultantes de várias dinâmicas socioambientais que integram o mesmo sistema de gestão estatal, mas que revelam lógicas territoriais distintas. A reflexão sobre as referidas políticas enseja a importância de se pensar também a relação sobre os usos e os dispositivos de gestão dos territórios protegidos sobrepostos. 


\subsection{GESTÃO SOCIOAMBIENTAL E O USO}

Oficialmente, os territórios protegidos se concretizaram no espaço com a justificativa de cumprirem um papel de conservação, proteção e fortalecimento cultural. Tais territórios desempenham também um papel geopolítico estratégico não explícito nas políticas que os ordenam. Mas em detrimento disso e considerando apenas o caráter oficial em uma perspectiva socioambiental, focada na problemática das sobreposições, o que se torna primordial para a função desses territórios é a relação entre os dispositivos de gestão e os usos no chão dos territórios. Dito de outra forma: no atual cenário onde os territórios protegidos já são uma realidade (respaldada pela constituição), o desafio é mantê-los conforme seus objetivos, e para tal uso e gestão são fundamentais.

De um modo geral o termo gestão representa o conjunto de ações destinadas ao planejamento, e é aplicável a diversas esferas: empresarial, pública, saúde, etc. No contexto dos territórios protegidos, além dessa caraterística de viabilizar o planejamento, a gestão envolve de maneira ampla aspectos políticos, econômicos e de proteção, que compõem a dinâmica territorial que sustenta UCs e TIs. As primeiras se inserem no âmbito da gestão ambiental e as segundas se inserem numa estrutura de gestão ainda em construção, que é a indigenista.

O desenvolvimento dos territórios amazônicos ocorreu em contextos de intensas intervenções dos grandes projetos governamentais. A diversidade socioambiental do bioma foi, historicamente, uma ferramenta para o modelo de desenvolvimento proposto nos moldes da gestão estatal. Sendo assim, a gestão do poder público é um elemento fundamental de investigação para se compreender os cenários amazônicos atuais. É o 'vetor básico de análise' como afirmou Bertha Becker:

A gestão entendida como a estratégia e a prática do Estado para a
ocupação recente da região é, portanto, vetor básico da análise,
embora não exclusivo na medida em que se procura identificar o papel
das várias forças sociais na expansão da fronteira e na produção de
uma nova Amazônia(BECKER, B.K. 2010, p.20).

Em função da força que o modelo de gestão estatal exerce sobre os territórios amazônicos, este foi escolhido como fio condutor de inserção ao estudo aqui proposto e à própria problemática das sobreposições. Entende-se, portanto, que a manutenção dos territórios está fortemente relacionada à estrutura de gestão estatal. Os métodos de gestão do Estado se inseriram como fator determinante na ocupação histórica e figuram atualmente com um papel central na manutenção dos territórios. Ainda que se considere 
a interação dos demais segmentos sociais no processo, os instrumentos de comando e controle utilizados pelo poder público é que norteiam a interação entre o uso e a dimensão política e ambiental em escala nacional.

$\mathrm{Na}$ gestão ambiental as ferramentas de comando instituídas pelo Estado por meio da Política Nacional do Meio Ambiente (PNMA) funcionam a partir do estabelecimento de padrões de qualidade, restrições e proibições de atividades como acontece no Zoneamento $^{15}$ e no licenciamento ambiental. São utilizados também mecanismos econômicos de incentivos fiscais e tributação sobre taxas de poluição. Ainda neste contexto da gestão ambiental estatal, ferramentas comunicacionais que abarcam educação ambiental, informação ao público, etc. também são utilizadas (FLORIANO, E.P. 2007).

As ferramentas de gestão de TIs instituídas pela PNGATI estão centradas nas técnicas de Etnozonemento, utilizadas para definir regras de uso e ocupação no interior das TIs, e de Etnomapeamento ${ }^{16}$ (mapa cultural), que coloca na perspectiva espacial os símbolos culturais indígenas. Ambas as ferramentas são elaboradas pelas comunidades a partir de metodologias colaborativas (MACHADO, M.C. 2014).

As questões socioambientais envolvidas na manutenção e transformação dos territórios protegidos são observadas, nesta pesquisa, a partir das perspectivas empírica e teórica. Do ponto de vista empírico estão as diretrizes e instrumentos do SNUC e da PNGATI, juntamente com os usos realizados pelas comunidades. Já na perspectiva teórica, gestão e uso correspondem às Territorialidades, conforme será detalhado adiante. Trata-se, portanto, de uma correlação entre empírico e teórico na dinâmica dos territórios protegidos. Assim, o conceito de gestão, aqui trabalhado, passa por duas concepções: a estatal, que funciona a partir dos mecanismos de comando e controle e é implementada pela política ambiental e indigenista, e a dos usos existentes em cada território. Para abarcar as referidas concepções, utiliza-se o termo Gestão Socioambiental.

Em tese, as normativas das referidas políticas possibilitam ou limitam as atividades e ações no interior dos territórios protegidos. Os habitantes dessas terras partem desse conjunto de normas para realizar o planejamento de suas atividades, independente de segui-las de fato. Pensando nessa relação entre as diretrizes que compõem as políticas e o uso praticado nos territórios, é possível inferir que as

\footnotetext{
${ }^{15} \mathrm{O}$ zoneamento será especificado no cap. 2

${ }^{16}$ As ferramentas de gestão instituídas na PNGATI serão especificadas no cap.2
} 
condições de tal relação impactam a conservação. Isso porque essa correspondência representa o rebatimento das políticas públicas nacionais nos sistemas socioambientais locais. Além disso, tal associação evidencia as especificidades de cada território.

$\mathrm{O}$ conceito de sustentabilidade vem à tona novamente para auxiliar no entendimento dos usos dos territórios. Apesar das contradições do conceito, este contribui para a superação do antigo conceito de adaptação ${ }^{17}$ aplicado às comunidades indígenas e ainda facilita a interlocução com as políticas públicas. Diante da variedade de concepções, aplicações e contextos que envolvem a sustentabilidade como tema tangente à questão socioambiental, o conceito de Sustentabilidade Ecológica trabalhado por Lima\&Pozzobon (2005,p.45) definido como 'capacidade de uma dada população de ocupar uma determinada área e explorar seus recursos naturais sem ameaçar, ao longo do tempo, a integridade do meio ambiente', representa bem a importância dos usos dos sistemas naturais.

Com base em tal conceito, a capacidade de acessar os recursos naturais sem comprometer os cenários futuros é medida pelas técnicas de manejo, representação da natureza e interação com o mercado financeiro. Cada território apresenta respostas diferentes a cada item mencionado, e por meio de tais respostas é que se chega aos níveis de conservação. Pela diversidade existente nos territórios protegidos, a análise destes deve ser realizada em diálogo com os usos, que refletem a realidade específica de cada território e por consequência respondem às políticas públicas nacionais de uma forma diferente.

Conforme a análise de Lima\&Pozzobon (2005), mesmo no caso das comunidades indígenas reconhecidas por sua vocação ecológica - o que os autores denominam como estereótipos consagrados - deve-se observar as variáveis mencionadas acima para se afirmar a capacidade de conservação. A partir da observação dos usos, o que envolve aspectos do modo de vida, a realidade encontrada se mostra complexa. Por exemplo, para comunidades indígenas dependentes da produção mercantil que vivem em terras pequenas localizadas nas proximidades de centros urbanos e/ou de grandes vias, como a Transamazônica, as condições de se implantar técnicas de manejo sustentáveis e tradicionais são bem mais restritas. Esse tipo de comunidade enfrenta o seguinte dilema:

Eles têm a desvantagem de estarem ligados a um território que, se lhes garante o reconhecimento da singularidade étnica e lhes oferece os supostos benefícios da tutela governamental, não lhes permite

\footnotetext{
${ }^{17}$ A noção de adaptação era entendida mais como uma forma de sujeição das sociedades indígenasao domínio da natureza do que como um ajuste que certamente ocorre nessas sociedades.
} 
sobreviver de acordo com seu modelo econômico tradicional, colocando-os frente ao dilema de viver num ambiente economicamente desfavorável ou de migrar para as cidades ou áreas rurais mais distantes e perder os benefícios ligados à Territorialidade. (LIMA, D. \& POZZOBON, J 2005.p.59)

A correlação entre as estruturas de gestão e os usos dos territórios mediados pelo conceito de Sustentabilidade Ecológica nos apresenta também a diversidade amazônica isenta de conceitos pré-determinados, pois destaca nos territórios: o histórico, as problemáticas internas, seus modos de vida, suas técnicas de manejo, etc. Desse modo, as populações se inserem como sujeitos políticos que compartilham da responsabilidade pela conservação, mas que para tal necessitam de condições para uma gestão socioambiental. A análise dos usos pressupõe a manipulação de dados empíricos, como bem destaca Lima\&Pozzobon (2005),

Uma vez que já não cabem mais as antigas dicotomias, fundadas em conceitos de caráter um tanto apriorísticos e que não davam conta da grande diversidade observada em campo, o novo contexto analítico abre espaço para abordagens mais empíricas do que teóricas para estudar a relação entre populações e ecossistemas. Uma análise baseada na verificação empírica da sustentabilidade dos usos que fazem as populações humanas dos ecossistemas produz, desta forma, uma ordenação da diversidade social segundo critérios ambientais. (LIMA, D. \& POZZOBON, J.p.47)

A inserção de dados empíricos contundentes nos estudos socioambientais é de fundamental importância para uma abordagem científica e consistente da temática. No entanto, vale ressaltar neste contexto, a relevância das correlações entre tais dados e as reflexões teóricas. No processo de busca pela compreensão da realidade por meio do método científico essa conexão contribui para que a comunidade científica consiga fundamentar a abordagem da problemática socioambiental, e ainda realizar o acompanhamento epistemológico de suas bases disciplinares. Nesta pesquisa, o esforço para realizar a referida correlação está contido na análise integrada entre as premissas do conceito de Territorialidade e os aspectos empíricos da estrutura de gestão e dos usos dos territórios protegidos aqui abordados.

Um dos princípios do conceito de Territorialidade é a sua própria definição conceitual ser realizada a partir da concepção das relações de poder instituídas num dado território. Nesse sentido, o poder está relacionado à capacidade de criar e controlar um território no âmbito simbólico ou material. Campos (2006, p.97) define tal habilidade como um "conjunto de práticas e suas expressões materiais e simbólicas, 
capazes de garantir a apropriação e permanência de um dado território por um determinado agente social". As quais, por sua vez, definem o próprio conceito de Territorialidade.

De acordo com tal premissa, os referidos temas - gestão e usos - são entendidos como Territorialidades por serem os mecanismos responsáveis pelo controle, manutenção e transformação dos territórios protegidos. A relação de poder nesses territórios ocorre entre as comunidades locais e o Estado, nas escalas local e nacional. Por um lado, a estrutura de gestão formada pelas políticas ambiental e indigenista representa o poder estatal, ou seja, a capacidade do Estado de criar e manter os territórios. Por outro, os usos praticados em escala local representam o poder interno às comunidades, ou seja, a capacidade que elas têm de sustentar, transformar e produzir sentido nos territórios.

A dinâmica entre essas duas realidades representa a relação de poder por meio da qual os territórios protegidos se mantêm e produzem sentido. Desse modo, o conceito de Territorialidade é intrinsicamente ligado às relações de poder na apropriação e dominação do espaço. É a partir da apropriação social que a Territorialidade possui o potencial de criar, manter, transformar, destruir e reconstituir o território. Trata-se de um conceito que estabelece correspondência direta com a dinâmica de transformação e (re)significação do espaço por meio da criação e permanência dos territórios. Nas palavras de Sack (apud Saquet, 2007, p.83) a "Territorialidade é uma expressão geográfica primária do poder social”.

Para além das relações de poder (controle social), o referido autor destaca outras duas facetas que, para ele, compõem o cerne da Territorialidade, são elas: classificação definição de áreas e comunicação (redes). Em qualquer uma delas, fica evidente o caráter humano do conceito e de sua correspondência com a realidade, neste caso com os sistemas naturais. A Territorialidade, para além da criação e manutenção da ordem também se torna um esquema para criar, transformar e manter o contexto geográfico por meio do qual experimentamos o mundo e lhe damos significado. (SACK apud Saquet, 2007). 


\subsection{TERRITÓRIO USADO}

A dinâmica das Territorialidades, pautada na relação de poder entre Estado e comunidades, representa a apropriação do espaço pela sociedade na formação dos territórios protegidos. Neste contexto, a abordagem territorial aqui proposta - elaborada no âmbito da perspectiva socioambiental - enfoca territórios com aptidão para a conservação, que em geral se destacam por seus sistemas naturais, mas que apenas produzem sentido conservacionista a partir da apropriação social realizada em escala nacional e local.

Tal argumento encontra respaldo no conceito de Território Usado, proposto por Milton Santos, em função do destaque à dimensão social do espaço e à possibilidade de análise multiescalar que o autor busca desenvolver na formulação de tal conceito. Nas primeiras reflexões sobre a concepção de Território Usado, Santos (1994, p.15) diz que "É o uso do território, e não o território em si mesmo, que faz dele objeto da análise".

Além de fundamentar a importância da dimensão social do espaço, a referida categoria subsidia a demanda, aqui proposta, de realizar um diálogo multiescalar. Conforme o pensamento de Santos (op.cit.), elaborado num contexto de ruptura com a noção de território herdada da modernidade que ele chama de incompleta, o conceito de Território extrapola o paradigma de Estado-Nação, ao considerar os usos e as diferentes escalas. Estes apropriados ao modo de vida, às técnicas e às ferramentas informacionais disponíveis no mundo após o fenômeno da globalização.

Nesse sentido, Santos (op.cit) argumenta que tal concepção é indispensável para a compreensão do funcionamento do mundo presente, pós-globalização, e se coloca como sinônimo de espaço geográfico situado na mediação entre o mundo, a sociedade nacional e local. Assim, a escolha do conceito de Território Usado, para esta pesquisa, se deve à natureza do tema e à construção do objeto de pesquisa para as quais a dinâmica de uso dos territórios numa dimensão multiescalar é imprescindível.

Considerando-se os usos do território é possível notar suas várias dimensões: econômica, cultural, política, etc. o que atribui um caráter múltiplo à categoria. $\mathrm{O}$ entendimento dessa multiplicidade é recorrente nas abordagens de Rogério Haesbaert, nas quais a relação entre o material e o simbólico é a base para a proposta de uma abordagem territorial múltipla, que contemple a diversidade dos territórios. Na concepção do autor, essas múltiplas dimensões estão atreladas, ainda, às relações de poder, que por sua vez se manifestam em esferas diversas. Para o autor, 
desde a origem, o território nasce com uma dupla conotação, material e simbólica, pois etimologicamente aparece tão próximo de terraterritorium quanto de terreo-territor (terror, aterrorizar), ou seja, tem a ver com dominação (jurídico-política) da terra e com a inspiração do terror, do medo - especialmente para aqueles que, com esta dominação, ficam alijados da terra, ou no 'territorium' são impedidos de entrar. Ao mesmo tempo, por extensão, podemos dizer que, para aqueles que têm o privilégio de usufrui-lo, o território inspira a identificação (positiva) e a efetiva 'apropriação'. Território, assim, em qualquer acepção, tem a ver com poder, mas não apenas ao tradicional "poder político". Ele diz respeito tanto ao poder no sentido mais concreto, de dominação, quanto ao poder no sentido mais simbólico, de apropriação. (HAESBAERT, R. 2004. Grifo Meu).

A partir do entendimento do Território enquanto realidade e categoria de análise, cuja complexidade consiste nas dinâmicas socioespaciais, admite-se que as possibilidades de recorte analítico são múltiplas. Seguindo tal premissa, mas considerando também as limitações teóricas, metodológicas e empíricas da pesquisa, apenas as dimensões política e ambiental são enfocadas na análise. Tais dimensões se inserem nesta conjuntura com a função de subsidiar uma abordagem inspirada na multiplicidade dos territórios, mas, elaborada na perspectiva de integração socioambiental. A sinergia com os usos e a gestão se torna complementar ao conceito de Território Usado aplicado aos territórios protegidos corroborando a característica multidimensional dos territórios. Assim, o território, neste caso, só é protegido a partir de seus usos.

O foco nos usos enseja à dinâmica dos territórios, remete ao movimento de seu processo de territorialização, ou seja, de criação e continuidade desses. Nesse sentido, os aspectos de apropriação e (re)significação dos territórios estão em constante mudança em função das Territorialidades predominantes em cada momento, em cada escala. Essa condição - a de constante mudança - também é abarcada nas reflexões de Santos (1999b), quando ele diz que

essa ideia de território usado, a meu ver, pode ser mais adequada à noção de um território em mudança, de um território em processo. Se o tomarmos a partir de seu conteúdo, uma formaconteúdo, o território tem de ser visto como algo que está em processo. E ele é muito importante, ele é o quadro da vida de todos nós, na sua dimensão global, na sua dimensão nacional, nas suas dimensões intermediárias e na sua dimensão local. (SANTOS, M. 1999b p.19)

Desse modo, os territórios protegidos são dinâmicos em função de seus usos e da gestão, ou seja, das Territorialidades que incidem sobre eles. Nesse processo, o sistema 
responsável pela criação e continuidade dos Territórios Protegidos no Brasil (territorialização) revela diferentes relações com o espaço, protagonizadas por diferentes atores sociais nas escalas nacional e local (conforme demonstrado no tópico 1.1).

$\mathrm{Na}$ configuração territorial, essa distinção entre tais apropriações revela significados específicos e também distintos. Nesse sentido, Haesbaert (2004) trabalha com noções fundamentais para a análise aqui proposta: dominação e apropriação. $\mathrm{O}$ autor observa, com base em Henri Lefebvre, a diferença e a relação conflituosa entre dominação e apropriação no contexto de usos do território praticados por atores diferentes.

\begin{abstract}
O uso reaparece em acentuado conflito com a troca no espaço, pois ele implica "apropriação" e não "propriedade". Ora, a própria apropriação implica tempo e tempos, um ritmo ou ritmos, símbolos e uma prática. Tanto mais o espaço é funcionalizado, tanto mais ele é dominado pelos "agentes" que o manipulam tornando-o unifuncional, menos ele se presta à apropriação. Por quê? Porque ele se coloca fora do tempo vivido, aquele dos usuários, tempo diverso e complexo. (Lefebvre, 1986:411-412 apud HAESBAERT, R. 2004).
\end{abstract}

$\mathrm{Na}$ reflexão de Lefebvre (1986) ratificada por Haesbaert (2004 op cit) as discrepâncias entre dominação e apropriação dos territórios são interpretadas com destaque para as múltiplas possibilidades do uso do território, possível para aqueles que o vivencia. Em contraponto com uma funcionalidade única que resulta de uma relação de propriedade fora do tempo da diversidade, porque concebe o território como um meio de servir às estratégias capitalistas. Nesse sentido, Haesbaert (2004 op cit) ressalta que enquanto espaço-tempo vivido, o Território é sempre múltiplo, diverso e complexo, ao contrário do Território unifuncional proposto pela lógica capitalista hegemônica".

$\mathrm{Na}$ escala local, os territórios protegidos são territórios usados com as referidas características da multiplicidade que envolve tempos, técnicas e concepções típicas das comunidades que os vivenciam. No chão dos territórios, são esses aspectos que impactam no nível de conservação dos sistemas naturais ao mesmo tempo em que fortalecem os modos de vida locais. $\mathrm{Na}$ escala nacional, os territórios protegidos são territórios usados a partir de uma relação de propriedade que serve às estratégias do Estado em suas necessidades de governo, soberania nacional, relações internacionais e concepção de desenvolvimento econômico. A relação de propriedade que o Estado estabelece com os territórios tem sentido estratégico para manter suas estruturas de poder. 
Nessa dinâmica territorial entre atores nacionais e locais, Becker (2009) se atenta ainda para os atores internacionais, num olhar sobre a geopolítica dos territórios protegidos da Amazônia. A autora observa que tanto no contexto das UCs quanto das TIs entidades internacionais, que representam financiamentos de projetos, inserem-se como mediadores na relação entre as populações locais e o Estado, impactando nas políticas públicas indigenistas e ambientais. Nesse contexto, a autora lembra a recepção da autonomia indígena da Coordenação das Organizações Indígenas da Amazônia Brasileira (COIAB), pelo Estado na década de 1900.

E o governo brasileiro começou a aceitar essa premissa em 1991, vendo de modo positivo a possibilidade de financiamentos externos para ações de proteção ao ambiente na Amazônia implicando na demarcação e homologação de muitas e extensas áreas indígenas, delineando progressivamente uma nova política indigenista. As populações indígenas constituem hoje atores fundamentais no cenário político regional: vêm aumentando progressivamente, sua autonomia e seu poder de barganha frente ao Estado e aos grupos econômicos, graças à sua organização, ao governo e ao apoio financeiro e técnico de ONGs e de instituições estrangeiras. (BECKER, B.2009 p.105)

O Programa Áreas Protegidas da Amazônia (Arpa) instituído em 2002 com recursos da Global Environment Facility (GEF) por meio do Banco de Desenvolvimento da Alemanha é, no contexto das UCs, um exemplo da interferência de atores internacionais na relação de poder entre a União (nacional) e comunidades (local), no contexto dos territórios protegidos. Não só o Desenvolvimento Sustentável mencionado anteriormente, não pode ser pensado fora dos moldes do sistema econômico, mas a própria gestão dos territórios protegidos está, em alguma medida, inserida em tal lógica via programas e políticas públicas.

Em função da complexidade que envolve a dinâmica dos territórios protegidos em sobreposição na Amazônia, é que se inicia a análise a partir de um arcabouço teórico facilitador de uma abordagem integrada. As possibilidades de análise e de recorte oriundas das premissas dos conceitos de Territorialidade e Território Usado é que norteiam a discussão acerca dessa lógica territorial e a leitura dos referenciais empíricos que permeiam a questão.

Em tal lógica, as Territorialidades, num primeiro momento aparecem nos marcos histórico e espacial resultantes das relações de poder entre segmentos sociais - neste caso, movimento indígena e ambientalista - e o Estado. Num segundo momento, 
considerando que os territórios protegidos já se tornaram um fato concreto, com marcos legais e espaciais delimitados, essas Territorialidades passam a figurar num contexto de sustentação material e produção de sentido desses territórios. Desse modo, pode-se afirmar que a continuidade e o sentido conservacionista dos territórios estão diretamente relacionados aos dispositivos de gestão e uso destes. Portanto, encontram-se nessas Territorialidades os fundamentos empírico e teórico que dialogam com o conceito de Território Usado.

Este processo revela a complexa lógica de territorialização dos Territórios Protegidos. Em síntese, parte-se do princípio de que o Território se torna categoria de análise a partir do uso. Com referência em tal pressuposto teórico as transformações territoriais podem evidenciar os usos. Com base em tais formulações é possível inferir que os usos determinam o caráter conservacionista e consequentemente o sentido dos Territórios Protegidos.

A análise de tal lógica pressupõe uma perspectiva integrada de seus aspectos socioambientais. Compreendendo desse modo os aspectos teóricos do objeto de estudo aqui construído é que se projeta nos próximos capítulos o intuito de analisar as políticas públicas e seus dispositivos de gestão, em correspondência com as transformações territoriais observadas com o auxílio dos indicadores socioambientais. 


\section{CAPÍTULO II - AS POLÍTICAS PÚBLICAS E OS INDICADORES DE TRANSFORMAÇÕES TERRITORIAIS: UMA PROPOSTA DE LEITURA ESPACIAL}

O segundo capítulo concentra, em sua maior parte, informações sobre as políticas públicas de gestão dos Territórios Protegidos. Neste aspecto tem-se a proposta de leitura espacial, um panorama geral e a classificação do SNUC e da PNGATI. Apresenta-se também os indicadores socioambientais utilizados para analisar a relação entre as transformações territoriais e as diretrizes e objetivos de tais políticas. Tal análise suscitou algumas reflexões secundárias - em relação ao tema central da pesquisa porém de extrema importância para o debate proposto. Trata-se dos conceitos de preservação e conservação, e da postura do Estado brasileiro frente a questão socioambiental. Nestas reflexões não se pôde ignorar a relação entre o cenário global, nacional e local. Este capítulo é mais denso que o primeiro, pois além de apresentar aspectos específicos do objeto de estudo, traz reflexões pertinentes ao tema e ainda delimita forma e conteúdo a serem desenvolvidos no terceiro capítulo.

\subsection{LEITURA ESPACIAL DAS POLÍTICAS PÚBLICAS}

As políticas públicas desempenham um papel fundamental na configuração do território nacional, pois impactam na sua organização interna e também nas relações internacionais. Tais impactos se concretizam no campo de atuação de tais políticas, que é divido entre setores, tais como: econômico; social; cultural; etc; Ou seja, existe uma lógica setorial de elaboração e implementação de suas diretrizes e objetivos. Nesse contexto, o Estado se insere como agente social responsável pela criação e acompanhamento desse processo, e o faz por meio de ferramentas de comando e controle. Alguns espaços de participação social também fazem parte desse processo.

Neste cenário, o protagonismo do Estado se torna evidente e encontra respaldo nas Políticas Públicas em vigor, em especial aquelas aqui estudadas - SNUC e PNGATI - Essa atual conjuntura se insere num movimento de retomada e reformulação das políticas públicas estatais, que conforme destaca Steinberger (2006), teve início nos 
primeiros anos do séc. XXI. O referido sentido de retomada se aplica ao considerar um período de 'enfraquecimento' dessas políticas e do próprio papel do Estado, atribuído às consequências da ditadura militar e ao advento da globalização e do neoliberalismo. Diante dessa reflexão, a referida autora destaca ainda que o Estado de agora não pode mais desconsiderar a existência de poderes plurais, de novos sujeitos e dos movimentos sociais urbanos e rurais.

O intuito de compreender a referida dinâmica das políticas públicas, a partir de uma perspectiva geográfica, fundamenta-se em sua dimensão espacial. Conforme diz Serpa (2011, p.37) "se há alguma especificidade do conhecimento geográfico relativa às políticas públicas, ela está na dimensão espacial que permeia a temática”. Nesse sentido, o referido autor destaca algumas possibilidades de se observar a espacialidade das políticas, como por exemplo, na distribuição espacial dos programas, nos planos e projetos desenvolvidos em território nacional e nas desigualdades regionais advindas da formulação e da implementação das políticas públicas brasileiras.

Serpa (2011) complementa seu raciocínio destacando outra possibilidade de contribuição da Geografia para a análise dessa temática: a capacidade de articulação entre escalas e recortes espaciais. Investigar um dado objeto de estudo sob um recorte analítico construído em determinada escala, sem perder de vista sua conexão com outras escalas e outros recortes, talvez seja a síntese de uma abordagem geográfica. Em concordância com as colocações de Serpa ( op cit), somadas as contribuições de Steinberger (2006), como suporte teórico, destaca-se aqui a pretensão metodológica desta pesquisa: contemplar a dimensão espacial do SNUC e da PNGATI articulando as escalas local e nacional.

Retomando aqui o argumento de Steinberger (op cit) inserido num contexto que, segundo ela, é de retomada da importância das Políticas Públicas. A autora tem expectativa de que este momento possa ser favorável à proposta de um planejamento compartilhado, que sirva às transformações sociais, uma vez que o Estado já não pode mais negligenciar o poder - plural - dos movimentos sociais. Essa expectativa enseja explorar a ideia que desse compartilhamento surjam interesses espacialmente referidos de agentes sociais diversos. Assim, a proposta da autora é construir um referencial teórico para subsidiar a problemática da inserção do espaço nas políticas, numa abordagem que integre ambiental, territorial, regional, urbano e rural (as qualidades do espaço). 
Para compreender a proposta da referida autora é necessário discorrer sobre alguns elementos chave de seu pensamento. Para construir sua proposição, de que as políticas públicas são espacialmente fundamentadas, Steinberger (op cit) utiliza-se dos conceitos de Espaço, Território e Ambiente como norteadoras de seu argumento. Amparando-se na extensa obra de Milton Santos - principalmente na teoria espacial - A autora demonstra que o espaço é berço do território e do ambiente. Nesse sentido o territorial e o ambiental se inserem no conjunto de qualidades - indissociáveis - do espaço. Assim, o espaço é "produtor e produto da ação na sociedade humana"; levando ao entendimento de que "o espaço é social e é natureza" 18 (Steinberger, op cit, p.33).

Desse modo, a concepção de espaço, conforme apresenta Steinberger (2006), é fundamental para uma análise de políticas públicas que se proponha abarcar as relações sociais, os sistemas naturais, a formação dos territórios e suas transformações. A conjuntura desses elementos não se restringe aos seus respectivos setores específicos, pois se fundamentam no espaço que por tais características se torna

[...] a chave que nos permitirá mostrar por que no rol das políticas públicas nacionais, as políticas adjetivadas de ambiental, territorial, regional, rural e urbana são espacialmente fundamentadas [...] elas constituem um conjunto e que não devem ser concebidas separadamente. (STEIBERGER, M. 2006, p.33).

A dimensão espacial das políticas públicas já foi, em certa medida, compreendida por seus formuladores. Porém, o fundamento espacial de suas ações é constantemente confundido com a localização, ou endereço num processo de regionalização. Essa concepção, que trata o espaço como receptáculo, vem sendo reproduzida nas políticas setoriais, de maneira a não reconhecer as especificidades - ambiental, territorial, regional, urbana e rural - do espaço nas políticas. Conclui-se que são rotuladas como setoriais, mas são espaciais. Nesse sentido, Steinberger (op cit) afirma que as políticas são espaciais em sua gênese

\footnotetext{
${ }^{18}$ Essas afirmações acerca do espaço foram mencionadas aqui com o objetivo de destacar seu caráter dinâmico e socioambiental. Além disso, buscou-se delimitar concepções relevantes do posicionamento da autora adotada como referência. Vale ressaltar ainda que nestas características do espaço - dinâmico e socioambiental - encontra-se a possibilidade de realizar uma abordagem das Políticas Públicas que apresente os elementos que extrapolam a setorização. Nesse sentido, é que se apresenta aqui uma proposta de leitura espacial de políticas públicas nacionais. No entanto, admitir a dimensão espacial neste caso se difere de dissertar sobre a teoria do espaço de Milton Santos na qual se ampara Steiberger (op cit).
} 
não porque o espaço vem antes do território, mas porque o espaço é uma categoria permanente e histórica que gera sucessivas configurações territoriais também históricas que são a base da produção do espaço. Há portanto uma produção histórica de espaço e de território que para ser mais bem compreendida, deve ser feita a partir de frações do espaço e de frações do território usado (STEINBERGER, M. 2006, p. 45).

Com base nas referidas formulações, o esforço empreendido aqui consiste em analisar a gestão dos territórios protegidos a partir de dados e informações observadas nas escalas local e nacional. A proposta para tal é produzir informações com referência espacial - por meio dos indicadores socioambientais derivados das próprias Políticas Públicas - na perspectiva dos territórios e conectados às diretivas dessas políticas nacionais. Nesse sentido, apresenta-se neste capítulo a proposta de leitura espacial do SNUC e da PNGATI composta pela apresentação e classificação das políticas, seguidas da seleção dos indicadores socioambientais.

\subsection{PANORAMA GERAL DO SISTEMA NACIONAL DE UNIDADES DE CONSERVAÇÃO (SNUC) E DA POLÍTICA NACIONAL DE GESTÃO TERRITORIAL E AMBIENTAL DE TERRAS INDÍGENAS (PNGATI) NO BRASIL.}

\subsubsection{PNGATI}

No âmbito das políticas públicas nacionais a dimensão territorial da problemática que envolve a questão indígena e ambiental é abarcada na PNGATI e no SNUC ${ }^{19}$, conforme mencionado anteriormente. Essas políticas determinam as regras de criação e uso dos territórios protegidos, sendo, portanto, o ponto de partida para se analisar a gestão desses. Apresenta-se aqui uma síntese das referidas políticas - em formato de panorama geral - a ser utilizada posteriormente como subsídio para a discussão

proposta. É importante ressaltar que a descrição que se segue apresenta fielmente os conteúdos idealizados na elaboração das Políticas Públicas e, como registro de um ideal apresenta vários desdobramentos e divergências quando observados na realidade.

\footnotetext{
${ }^{19}$ A PNMA é a política pública nacional que determina normas, ações e programas de prevenção, mitigação, monitoramento e planejamento ambiental. No entanto, esta política não é a base de análise central nesta pesquisa por dois motivos: a princípio, pela extensão e complexidade da pesquisa, mas sobretudo pelo fato da Lei do SNUC ser, dentro da estrutura do PNMA, a normativa específica que trata da criação e gestão das UCs. Estes últimos que são aspectos fundamentais para o objeto de estudo aqui construído.
} 
A PNGATI foi instituída por meio do Decreto $N^{\circ} 7.747$ de 5 de junho de 2012 e teve como referência a convenção 169 da Organização Internacional do Trabalho $(\mathrm{OIT})^{20}$. Adota o princípio da autonomia indígena no processo de gestão de suas terras, mas ressalta também a importância e a responsabilidade do Estado na estruturação, implementação e monitoramento da Política Indigenista.

Os pilares para a gestão territorial e ambiental previstos na PNGATI são: proteção, recuperação, conservação e uso sustentável dos recursos naturais, pois se considera que a natureza é a base para o fortalecimento da cultura indígena. Assim, pode-se inferir que em seu contexto a autonomia dos povos indígenas e a presença estatal são fundamentais para se atingir as bases da gestão territorial e ambiental.

A PNGATI é apresentada a partir da seguinte estrutura: instrumentos de gestão, diretrizes, objetivos específicos e o sistema de governança ${ }^{21}$ da própria política. Em cada um desses pontos, estão presentes os pilares da gestão, citados no parágrafo anterior, que nortearam a elaboração do decreto. A princípio, são definidos os instrumentos para se atingir a gestão territorial e ambiental em terras indígenas: o Etnomapeamento e o Etnozoneamento. Essas duas ferramentas são mapeamentos colaborativos realizados para representar os símbolos da cultura indígena (Etnomapeamento ou Mapa Cultural ${ }^{22}$ ) e para definir regras de uso para cada área interna às TIs (Etnozoneamento). Esses mapas são elaborados e utilizados conforme a cultura e planejamento das comunidades para suas atividades produtivas, culturais, políticas, etc.

As diretrizes da PNGATI são apresentadas em 13 temas que expressam de forma mais específica, por meio de definição dos princípios, quais frentes de trabalho empenhar para se atingir a gestão territorial e ambiental nas terras indígenas (Tabela3).

\footnotetext{
${ }^{20}$ A Convenção 169 sobre Povos Indígenas e Tribais em Países Independentes da OIT aprovada em 1989, durante sua $76^{\mathrm{a}}$ Conferência, é o instrumento internacional vinculante mais antigo que trata especificamente dos direitos dos povos indígenas e tribais no mundo. Depois de quase 20 anos de sua aprovação, a OIT vem acumulando experiências na implementação dos direitos reconhecidos a esses povos.

${ }^{21}$ A expressão "governance" surge a partir de reflexões conduzidas principalmente pelo Banco Mundial, "tendo em vista aprofundar o conhecimento das condições que garantem um Estado eficiente" (Diniz, 1995, p. 400). Ainda segundo Diniz, "tal preocupação deslocou o foco da atenção das implicações estritamente econômicas da ação estatal para uma visão mais abrangente, envolvendo as dimensões sociais e políticas da gestão pública" (Ibid., p. 400). A capacidade governativa não seria avaliada apenas pelos resultados das políticas governamentais, e sim também pela forma pela qual o governo exerce o seu poder (GONÇALVES, A. 2005).

${ }^{22}$ Para mais informações sobre o uso dos Etnomapas ver MACHADO, M. 2014.
} 


\begin{tabular}{|l|}
\hline Diversidade Cultural \\
\hline Fortalecimento Político dos indígenas - interno e externo \\
\hline Autonomia Sociocultural \\
\hline Papel das Mulheres na Conservação \\
\hline Conservação dos Ecossistemas nos Biomas onde se localizam as Terras Indígenas \\
\hline Proteção Ambiental e Territorial \\
\hline Proteção Ambiental e Territorial em Áreas de Isolados \\
\hline Implementação da PNGATI para índios que vivem em áreas urbanas \\
\hline Proteção aos Saberes Tradicionais \\
\hline Gestão Ambiental como Instrumento de Proteção \\
\hline Garantia do Direito ao Consentimento Prévio' \\
\hline Direitos Relativos aos Serviços Ambientais \\
\hline Parcerias para Integração da PNGATI com Políticas Locais e Regionais \\
\hline
\end{tabular}

Tabela 3 - Temas norteadores das diretrizes da PNGATI.

Os objetivos específicos estão divididos em sete eixos temáticos voltados principalmente ao reconhecimento, valorização e incentivo para que os povos indígenas alcancem melhorias e participação ativa nas seguintes áreas:

\begin{tabular}{|c|c|}
\hline$\overline{8}$ & Proteção Territorial e dos Recursos Naturais \\
\hline & Governança e Participação IndígenaÁreas Protegidas, \\
\hline & Unidades de Conservação e Terras Indígenas \\
\hline & Prevenção e recuperação de danos Ambientais \\
\hline & Uso Sustentável de Recursos Naturais e Iniciativas Produtivas Indígenas \\
\hline & Propriedade Intelectual e Patrimônio Genético \\
\hline & Capacitação, Formação, Intercâmbio e Educação ambiental. \\
\hline
\end{tabular}

Tabela 4 - Áreas Prioritárias para os Objetivos Específicos da PNGATI. 
No que diz respeito à governança da própria política são determinados órgãos com a função de elaboração, implementação e monitoramento da PNGATI são eles:

- Comitê Gestor da PNGATI

- Comitês Regionais da FUNAI

- Comissão Nacional de Política Indigenista (CNPI)

Esses órgãos responsáveis pela governança são formados por representantes do Ministério da Justiça (MJ) e do Meio Ambiente (MMA) e pelos representantes das comunidades indígenas. O comitê é responsável pela coordenação, execução, monitoramento, articulação e promoção de ações necessárias à implementação da política no âmbito do Plano Plurianual (PPA), das diretrizes orçamentárias e do orçamento anual. A coordenação do comitê deve ser alternada entre MJ e MMA e a secretaria executiva exercida pela FUNAI. O comitê deve ainda propor a realização da conferência nacional da PNGATI. A CNPI deve acompanhar, a implementação da PNGATI, a fim de articulá-la às demais políticas públicas de interesse dos povos indígenas.

\subsubsection{SNUC}

O SUNC, criado através da Lei $N^{\circ} 9.985$ de 18 de Julho de 2000, regulamenta o art. 225 da Constituição Federal e é responsável pela criação, implantação e gestão das UCs do Brasil. A Lei apresenta a seguinte estrutura: definição dos termos utilizados no documento; definição das UCs federais, estaduais e municipais como integrantes do sistema; objetivos; diretrizes; estrutura de governança; categorias de UCs e as normas sobre a criação, implantação e gestão dessas. Por fim, apresenta incentivos, isenções e penalidades. Também esclarece sobre os aspectos específicos das Reservas da Biosfera (BRASIL, Lei $\mathrm{n}^{\circ} 9.985$ de 18 de julho de 2000).

No contexto da referida estrutura, cabe destacar a definição de cinco conceitos relevantes para esta pesquisa, a saber: UC; zoneamento; plano de manejo; zonas de amortecimento e corredores ecológicos. Para efeito da Lei do SNUC, as UCs são compreendidas como: 
Espaço territorial e seus recursos ambientais, incluindo as águas jurisdicionais, com características naturais relevantes, legalmente instituído pelo Poder Público, com objetivos de conservação e limites definidos, sob regime especial de administração, ao qual se aplicam garantias adequadas de proteção (BRASIL, Lei n ${ }^{\circ} 9.985$ de 18 de julho de 2000).

O zoneamento faz parte do mecanismo necessário à gestão das UCs. Trata-se de um procedimento que define setores ou zonas de acordo com as aptidões dos sistemas naturais e dos usos específicos compatíveis a tais áreas. Essa diferenciação também garante que o objetivo da UC seja respeitado regulamentando as especificidades de cada uma. Por isso, o zoneamento é peça-chave na elaboração do plano de manejo, que nos termos da Lei ele é definido como

documento técnico mediante o qual, com fundamento nos objetivos gerais de uma unidade de conservação, se estabelece o seu zoneamento e as normas que devem presidir o uso da área e o manejo dos recursos naturais, inclusive a implantação das estruturas físicas necessárias à gestão da unidade (BRASIL, Lei nº 9.985 de 18 de julho de 2000).

Assim, o plano de manejo como instrumento de gestão centrado nas regras do zoneamento é aplicável tanto à área interna das UCs quanto às áreas de entorno. Isso ocorre porque as dimensões territoriais necessárias à conservação e proteção da biodiversidade possuem limites próprios dos ecossistemas. Para abarcar esta realidade, a legislação prevê regras específicas também para o entorno das UCs, que é considerado como zona de amortecimento. Seguindo o mesmo raciocínio, a importância dos corredores ecológicos formados pela proximidade de várias áreas protegidas, também é contemplada nesse conjunto de diretrizes e regras. No SNUC encontra-se a seguinte definição e regras de usos para essas áreas:

Zona de amortecimento: o entorno de uma unidade de conservação, onde as atividades humanas estão sujeitas a normas e restrições específicas, com o propósito de minimizar os impactos negativos sobre a unidade [...] Corredores ecológicos: porções de ecossistemas naturais ou seminaturais, ligando unidades de conservação, que possibilitam entre elas o fluxo de genes e o movimento da biota, facilitando a dispersão de espécies e a recolonização de áreas degradadas, bem como a manutenção de populações que demandam para a sua sobrevivência áreas com extensão maior do que aquela das unidades individuais (BRASIL, Lei n 9.985 de 18 de julho de 2000). 
Os objetivos do SNUC têm o intuito de proteger, preservar, recuperar, valorizar e promover ações que contribuam para a proteção e conservação ambiental em aspectos específicos (Tabela 5).

\begin{tabular}{|c|}
\hline $\begin{array}{l}\text { Diversidade Biológica e Recursos Energéticos no território nacional e nas águas } \\
\text { jurisdicionais }\end{array}$ \\
\hline Espécies Ameaçadas de Extinsão \\
\hline Ecossistemas Naturais / Degradados \\
\hline Desenvolvimento Sustentável \\
\hline Paisagens de Notável Beleza Cênica \\
\hline $\begin{array}{l}\text { Característica de Natureza geológica, geomorfológica, espeleológica, arqueológica, } \\
\text { paleontológica e cultural }\end{array}$ \\
\hline Recursos hídricos e edáficos \\
\hline Monitoramento Ambiental \\
\hline Socioeconomia ligada à diversidade biológica \\
\hline Educação e Interpretação Ambiental - Turísmo Ecológico \\
\hline Importância das Populações Tradicionais \\
\hline
\end{tabular}

Tabela 5 - Objetivos do SNUC

Já as diretrizes estão relacionadas ao intuito de assegurar que nas UCs tenham os seguintes elementos listados na Tabela 6 


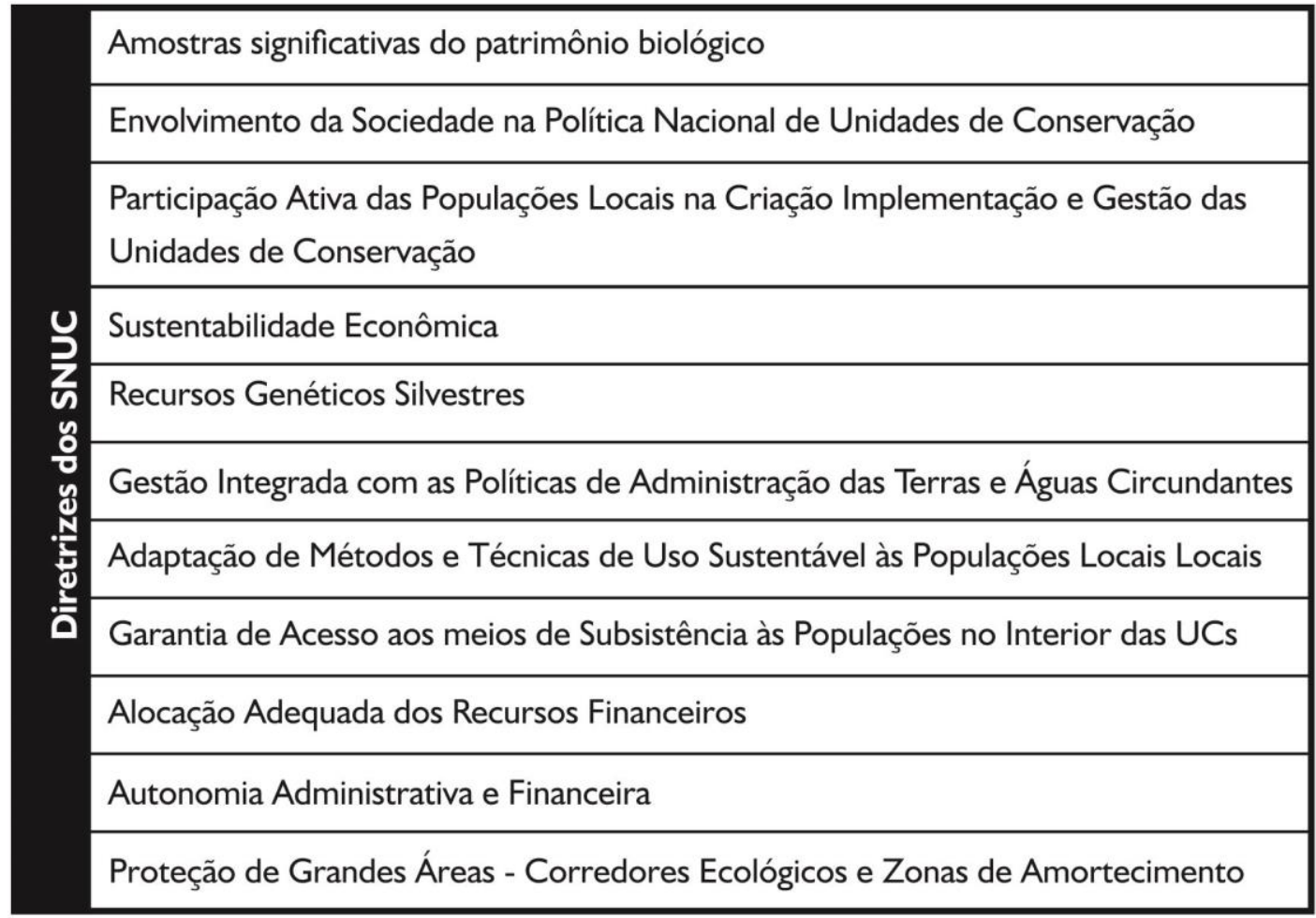

Tabela 6 - Diretrizes do SNUC

A gestão do SNUC fica a cargo dos seguintes órgãos e instituições:

- Conselho Nacional do Meio Ambiente (CONAMA) - Órgão Consultivo e Deliberativo;

- Ministério do Meio Ambiente (MMA) - Coordenador do Sistema;

- Instituto Chico Mendes de Conservação da Biodiversidade (ICMBio), Instituto Brasileiro do Meio Ambiente e dos Recursos Naturais Renováveis (IBAMA) e Órgãos Estaduais e Municipais - Executores do Sistema.

As UCs são categorizadas como de Proteção Integral e Uso Sustentável (Tabela 7). O que diferencia esses grupos, na prática, é o tipo de uso permitido em cada uma. Para o primeiro grupo, cujo objetivo é preservar, é permitido apenas o uso indireto. Já no segundo grupo que tem como finalidade a conservação, o uso sustentável é permitido, incluindo atividades diretas como extrativismo e manejo de madeira. 


\begin{tabular}{|l|l|}
\hline Estação Ecológica & Área de Proteção Ambiental \\
\hline Reserva Biológica & Área de Relevante Interesse Ecológico \\
\hline Parque Nacional & Floresta Nacional \\
\hline Monumento Natural & Reserva Extrativista \\
\hline \multirow{2}{*}{ Refúgio da Vida Silvestre } & Reserva de Fauna \\
\cline { 2 - 2 } & Reserva de Desenvolvimento Sustentável \\
\cline { 2 - 2 } & Reserva Particular do Patrimônio Sustentável \\
\hline
\end{tabular}

Tabela 7 - Categorias de UCs

Vale ressaltar que o Decreto $N^{\text {o }} 4.340$ de 22 de agosto de 2002 regulamenta os artigos da Lei do SNUC que tratam dos seguintes assuntos: criação; subsolo e espaço aéreo; mosaico de UCs; plano de manejo; conselhos; gestão compartilhada com OSCIP; autorização para exploração de bens e serviços; compensação por impacto ambiental; reassentamento de populações tradicionais e reserva da biosfera.

Sobre a criação, implantação e gestão das UCs, a legislação dispõe que para a criação é necessário estudos técnicos e consulta pública à sociedade, exceto no caso das Estações Ecológicas e Reservas Biológicas que, segundo a Lei, não necessitam consulta pública. As UCs de uso sustentável poderão ser transformadas em proteção integral desde que observados os mesmos critérios de estudo técnico e consulta pública, da mesma forma, os limites podem ser ampliados. Fica estabelecido também que o espaço aéreo e o subsolo, sempre que influírem na estabilidade do ecossistema, integram os limites das UCs.

Em relação às sobreposições com outras áreas protegidas, a legislação prevê que, quando houver, a gestão deve ser feita de forma integrada e participativa, contemplando os objetivos de conservação das áreas em situação de sobreposição. A Lei prevê ainda que os órgãos federais responsáveis pela política ambiental e indigenista deverão instituir grupos de trabalho para regularização das eventuais superposições entre TIs e UCs.

O plano de manejo é o instrumento primordial para controlar os usos das UCs. Para tal ele deve ser elaborado no prazo máximo de cinco anos a partir da data de criação. Nesse poderá constar liberação para o cultivo de organismos geneticamente modificados nas Áreas de Proteção ambiental (APA) e nas zonas de amortecimento das 
demais categorias. É proibido a inservção de espécies não nativas nas áreas de UCs exceto nas APAs, FLONAs, RESEXs e RDSs.

Nos casos de licenciamento ambiental de empreendimentos de alto impacto ambiental, o empreendedor é obrigado a apoiar a implantação e manutenção de uma UC de proteção integral. O montante a ser destinado pelo empreendedor para tal finalidade não pode ser inferior a meio por cento dos custos totais previstos para a implantação do empreendimento. Quando o empreendimento afetar diretamente uma UC, ou sua zona de amortecimento, mesmo não sendo de proteção integral, deverá ser beneficiária.

Além da compensação ambiental, os recursos financeiros utilizados para a gestão das UCs são oriundos de: pagamento por utilização dos recursos das UCs, seja da paisagem ou de produtos da sociobiodiversidade, doações nacionais e internacionais de organizações privadas ou públicas ou de pessoas físicas. O governo deve submeter ao Congresso Nacional, a cada dois anos, um relatório sobre a situação das UCs do Brasil.

\subsubsection{Concepções de preservação e conservação no SNUC e na PNGATI}

Dentre os diversos temas abordados nas referidas políticas, alguns conceitos fundamentais, em especial os de conservação e preservação, merecem uma breve reflexão. A princípio, ambas as políticas apresentam como bases norteadoras de suas ações diretrizes e princípios semelhantes: proteção; conservação; recuperação; uso sustentável e valorização dos recursos naturais. No entanto, a concepção de preservação e conservação é diferente em cada uma. Apesar de se sobreporem no chão dos territórios, cada política responde às suas diretrizes norteadoras conforme contextos de criação e de governança próprios de seus setores, neste caso, diferenciados (ambiental e indigenista).

No SNUC, a proteção aos sistemas naturais é, em si, o foco principal, talvez pela influência do movimento ambientalista do qual é tributário. Tal concepção muda apenas nos aspectos que tratam da conservação, nesse caso o foco no uso serve ao mercado como, por exemplo, pela "exploração sustentável de florestas nativas" em Flonas, previsto em seu art. 17. A extensa Lei prevê ainda mecanismos de controle para cada elemento da paisagem, desde o subsolo até o espaço aéreo, ocupando-se inclusive do cultivo de organismos geneticamente modificados. Neste contexto, as populações 
tradicionais, os povos da floresta e a sociedade em geral são inseridos de forma complementar.

Na PNGATI, a concepção de proteção aparece sempre atrelada ao territorial e ao ambiental. Nos dois contextos a natureza é concebida como fator condicionante para a continuidade e o fortalecimento da cultura indígena. Evidentemente esse entendimento da relação entre sociedade e natureza, visto na política de gestão de TIs, vem sendo gestado desde os primeiros movimentos de resistência dessas comunidades. Os princípios norteadores dessa política, em função de seu histórico, apontam para as organizações sociais e para os ecossistemas ao mesmo tempo. Apesar de apresentar diretrizes mais socioambientais, o decreto não ampara boa parte da problemática da gestão de TIs, como por exemplo, as condições de elaboração, implementação e monitoramento dos planos de gestão.

É interessante observar também que existe uma diferenciação de complexidade e amplitude entre as referidas políticas. No caso da PNGATI, trata-se de um decreto que se apresenta mais generalizado, em relação a delimitação e amparo legal para implementação de seus objetivos. Já a Lei do SNUC apresenta um nível mais complexo de detalhes e uma série de mecanismos que respaldam sua implementação diante das diversas possibilidades relacionadas às UCs.

Essa reflexão sobre as políticas é importante para o entendimento das sobreposições e dos entraves que elas representam. Ao colocar SNUC e PNGATI na mesma perspectiva de leitura, pontuando suas especificidades e dispositivos de ação, a problemática em questão emerge principalmente pela delimitação do campo de cada política. Definir as possibilidades e os mecanismos dessas políticas esclarece a questão e evidencia elementos fundamentais para o debate. Sobretudo para a análise proposta, que é realizada no recorte espacial diretamente influenciado pelas ações dessas duas políticas e seus diferentes contextos. 


\subsubsection{Atitude do Estado frente a essas políticas ambiental e indigenista}

Os artigos 225 e 231 da Constituição Brasileira tratam, respectivamente, das formas de intervenção estatal nas questões ambiental e indígena. Nos termos da Carta Magna, é atribuição do poder público defender e preservar o meio ambiente ecologicamente equilibrado, como um direito de todos. No caso da questão indígena, a União é responsável pela demarcação e proteção das TIs, bem como por fazer respeitar os direitos dos indígenas e seus modos de vida. Dentre as ações realizadas na tentativa de cumprimento com tais responsabilidades, a criação de espaços territoriais protegidos (UCs) e demarcação de TIs são fundamentais.

Portanto, as formas de atuação do Estado, nestes casos, estão centradas no processo de criação, reconhecimento e gestão dos territórios protegidos. Especialmente na fase de gestão, que possibilita a continuidade destes, as políticas públicas são imprescindíveis como ferramentas do agir governamental ${ }^{23}$. Atendo-nos à referida etapa, SNUC e PNGATI são subsídios para se pensar a postura do Estado brasileiro frente às demandas ambiental e indígena. Em outras palavras, essas políticas podem ser lidas como indícios da postura estatal frente às necessidades de sustentação de cada tipo de território protegido aqui abordado.

O questionamento que se faz aqui é sobre a atitude do Estado frente ao ambiente e aos territórios indígenas do Brasil, em especial da Amazônia. Para fundamentar tal reflexão é importante delimitar concepções básicas sobre o conceito de Estado. Na Geografia, a preocupação com a geopolítica do Espaço proporcionou este debate e se desenvolveu no âmbito da chamada Geografia Política. Um marco dessa construção foi a obra Por uma Geografia do Poder, na qual se encontra, entre os primeiros apontamentos sobre a elaboração do conceito, a seguinte afirmação:

[...] Se há um conceito sobre o qual os geógrafos concordam é com certeza o da definição de Estado: 'o Estado existe quando uma população instalada num território exerce a própria soberania'. Portanto, três sinais são mobilizados para se caracterizar o Estado: a população, o território e a autoridade. Toda geografia do Estado deriva dessa tríade (RAFFESTIN, C. 1980, p.22).

\footnotetext{
${ }^{23}$ Aqui entende-se que o governo é uma instituição do Estado e as políticas públicas resultam da soma das atividades dos governos, que agem diretamente ou por delegação, e que influenciam a vida dos cidadãos. Peters (1986 apud Souza, 2006).
} 
Esse conceito foi privilegiado no desenvolvimento da Geografia Política em meados do século XX. Em tal contexto, o destaque dado ao poder estatal resultou em abordagens políticas incapazes de contemplar outros atores e outras escalas. A partir de 1980, a literatura mostra que o foco desse campo de estudo começa a se transformar. Steinberger (2006, p.29) diz que nesse período o "Estado Nacional entrou em agonia em quase todo o mundo ocidental”, talvez pela superação dos Estados totalitários e pelo advento da globalização. Com isso, o Estado perde espaço e, consequentemente as políticas públicas também. Nesse momento, se estabelece um embate. Por um lado a experiência do excesso de poder estatal gera oposição a este, e por outro, o enfraquecimento das políticas públicas fragiliza o país diante dos interesses externos.

Independente dos posicionamentos sobre esse impasse, atualmente assiste-se a uma retomada da importância do Estado e das políticas públicas sob seu comando. Mas essa retomada é acompanhada do fortalecimento dos movimentos sociais, e dos poderes plurais. Como reitera Steinberger:

O Estado de agora não pode ser mais aquele que desconhecia a existência de poderes plurais, sejam federativos ou dos interesses contra-hegemônicos de novos sujeitos sociais como os movimentos populares urbanos e rurais [...] as políticas públicas de agora não podem mais ser aquelas que definiam autoritariamente metas e recursos para sujeitos tomados como público-alvo, como se não tivessem projetos próprios (STEINBERGER, M. 2006, p.30).

A gestão dos territórios protegidos pressupõe a presença estatal e a dinâmica dos territórios. O Estado no cumprimento de suas atribuições constitucionais possibilita às comunidades locais a efetivação da gestão e do objetivo conservacionista. Nesse sentido, questionar a postura do Estado frente à questão socioambiental na Amazônia significa discutir também suas interações com a dinâmica territorial em escala local. A geopolítica dos territórios protegidos envolve poderes que podem ser analisados de forma "multidimensional" como sugeriu Raffestin (1980, pág. 29). A partir desse entendimento é que se procede a reflexão sobre a atitude estatal diante das demandas aqui abordadas.

A partir dos eventos que culminaram na criação do SNUC e da PNGATI, é possível fazer alguns apontamentos sobre os posicionamentos do Estado. A princípio, nota-se que os avanços na estruturação de uma política ambiental brasileira são obtidos, em grande parte, como resposta às pressões internacionais. Esse movimento ocorre em função da importância e visibilidade mundial da Amazônia. A floresta amazônica 
brasileira tem 5 milhões de $\mathrm{km}^{2}$, o que corresponde a 56\% do território nacional (IPEA, 2008). Devido a estas proporções, os governos do país são recorrentemente cobrados pela sua conservação (PAGNOCCHESCHI, B. \& BERNARDO, M.2006).

Assim, as ações e projetos voltados à inserção da questão ambiental na agenda dos governos, necessários para a consolidação da política ambiental, são constantemente posicionados como respostas às pressões internacionais. Como destacam Pagnocchesci\&Bernardo (op.cit.), na conjuntura de alguns acontecimentos dos anos 1980 e 2000 ,

\begin{abstract}
essa política ambiental 'pra fora' é um traço identificável nos mais variados momentos e governos [...] o conjunto de medidas do chamado Programa Nossa Natureza anunciado em 1989, que abriu caminho para um novo arranjo institucional no setor ambiental público foi a reação do governo brasileiro às crescentes pressões e repercussões acumuladas desde a morte do líder seringueiro Chico Mendes, em 1988. [...] Esse traço também ficou registrado em dezembro de 2002, quando o então recém-eleito presidente da República, Luís Inácio Lula da Silva, anunciou nos Estados Unidos, em entrevista coletiva, o nome de Marina Silva como ministra para o Meio Ambiente como garantia à comunidade internacional da seriedade com que o novo governo brasileiro trataria a Amazônia (PAGNOCCHESCHI, B. \& BERNARDO, M. p.102, 2006)
\end{abstract}

A conjuntura econômica internacional contribuiu para a efetividade desta influência, sobretudo quando bancos e fundos internacionais se apropriaram da pauta socioambiental. Essas instituições impuseram a avaliação de impacto ambiental aos projetos financiados, elaboraram regras para concessão de crédito - denominadas salvaguardas $^{24}$ - e passaram a investir diretamente nos projetos de desenvolvimento ambiental. O Banco Mundial, por exemplo, solicitou em 1988 relatórios de impacto ambiental dos projetos que financiou em determinados países, incluindo o Brasil. Isso porque o papel do banco em problemas ambientais brasileiros causava controvérsias no cenário político internacional, já imerso no debate socioambiental (MARGULIS,S. 1990).

O cenário interno foi pouco representativo no processo de inserção da problemática socioambiental na agenda dos governos. Os órgãos criados para tratar a questão mantiveram-se desarticulados de pastas com maior impacto na questão, como a de infraestrutura e produção de energia, por exemplo. As normativas ambientais ficaram dispersas entre os órgãos, apresentando lacunas em algumas áreas e sobreposições entre

\footnotetext{
${ }^{24}$ Sobre as salvaguardas do Banco Mundial, ver MARQUES, L.V;HACON,S.;VINHA, V. Os princípios do equador e o sistema financeiro - ferramentas para a gestão socioambiental brasileira. In: VIII ENGEMA, Rio de Janeiro, 2005.
} 
as eferas federal, estadual e municipal (PAGNOCCHESCHI, B. \& BERNARDO, M. 2006).

A criação do SNUC, no ano 2000, foi uma tentativa de centralizar os dispositivos legais de gestão ambiental. Ainda que tais discrepâncias permaneçam, é evidente que a criação da Lei foi um avanço nesse sentido, pois centralizou as normativas territoriais da área. Considerando a Conferência de Estocolmo (1972) como marco fundamental, esse avanço nada trivial, demorou aproximadamente três décadas para acontecer. Os estudiosos que se debruçam sobre a política ambiental brasileira desvendam seus problemas e até mesmo a falta de estudos para compreendê-la. No entanto, mesmo com as falhas, admite-se que o Estado brasileiro deu respostas relativamente rápidas e bem elaboradas ${ }^{25}$ à problemática ambiental.

Enquanto a criação da Lei do SNUC levou quase três décadas - a contar de Estocolmo - a PNGATI veio em quatro. Por outro lado, se considerarmos a resistência indígena frente ao Estado brasileiro como marco da construção de uma política indigenista de gestão, esse recorte temporal extrapola as mencionadas quatro décadas. Nesse sentido, pode-se inferir que o Estado tem levado mais tempo para dar respostas às demandas territoriais indígenas. Mesmo existindo algum nível de pressão do cenário geopolítico internacional somado às pressões internas (históricas) do movimento indígena.

A influência do cenário político externo na consolidação da política indigenista brasileira, tras dois marcos principais: a já mencionada convenção169 da Organização Internacional do Trabalho (OIT), como ícone dos diretos indígenas em 1989; e a ECO92, que possibilitou acordos de cooperação para demarcação e gestão de várias TIs. Internamente, esse processo foi movimentado por projetos específicos implementados pelo governo federal, Funai e ministérios. Machado (2014) destaca tais projetos e suas áreas de atuação (Tabela 8), a partir dos quais conclui que

com a evolução dos projetos relacionados às terras indígenas e com a mudança de contexto territorial das comunidades, surge a necessidade da construção de uma política a cerca de gestão territorial de terras indígenas a partir de fatores que exprimem mudanças no cenário político e social e também mudanças no olhar sobre comunidades indígenas (MACHADO, M. C. 2014, p.32).

\footnotetext{
${ }^{25}$ Bem elaboradas no sentido de apresentar dispositivos complexos como o SNUC, com normativas específicas para questões de natureza econômica, científica, política, etc.
} 
Projetos de Gestão Ambiental e Territorial em Terras Indígenas

\begin{tabular}{|l|l|l|l|}
\hline \multicolumn{1}{|c|}{ Projeto } & \multicolumn{2}{c}{ Objetivo } & 1996 \\
\hline $\begin{array}{l}\text { Projeto Integrado de Proteção às } \\
\text { Populaçõesão e Terras Indígenas da } \\
\text { Amazônia Legal (PPTAL) }\end{array}$ & Funai & Regularização Fundiária & 1996 \\
\hline Projetos Demonstrativos & MMA & Desenvolvimento Sustentável & 1996 \\
\hline $\begin{array}{l}\text { Projeto Demonstrativo dos Povos } \\
\text { Indígenas (PDPI) }\end{array}$ & MMA & $\begin{array}{l}\text { Projetos nas áreas ambiental, } \\
\text { cultural e econômica elaborados } \\
\text { pelas comunidades }\end{array}$ & 2001 \\
\hline Projeto Carteira Indígena & $\begin{array}{l}\text { Governo Federal, } \\
\text { MMA e MDS }\end{array}$ & $\begin{array}{l}\text { Segurança Alimentar dos Povos } \\
\text { Indígenas }\end{array}$ & 2003 \\
\hline
\end{tabular}

Tabela 8 - Trajetória dos projetos de gestão anteriores à PNGATI. Fonte: MACHADO, 2014.

Atualmente, o principal desafio de gestão das TIs é a elaboração e implementação dos PGTAs. Este documento viabiliza a inserção do planejamento realizado nas aldeias na esfera política estatal. No entanto, tal documento não está previsto na própria PNGATI, que considera o Etnozoneamento e o Etnomapeamento como ferramentas de gestão. Os PGTAs foram previstos no Plano Plurianual (PPA 2012 - 2015) do Governo Federal, mas o fato de não estarem na PNGATI dificulda a difusão de informações sobre os mecanismos de acesso aos recursos para elaboração desse planejamento (Funai, 2013).

A partir da trajetória do SNUC e da PNGATI, considerando os eventos que a influenciaram, fica evidente a diferença entre as respostas do Estado às demandas indígena e ambiental. A política de gestão das TIs foi elaborada 12 anos após a Lei do SNUC. Entre uma e outra, também é possível perceber a distância de estrutura e representatividade política. Com base nesses elementos de reflexão, coloca-se em questionamento a postura estatal que torna a política indigenista marginal no âmbito das demais políticas públicas.

\subsection{CLASSIFICAÇÃO DAS POLÍTICAS}

Para viabilizar a metodologia proposta, considerando a importância da conexão entre as políticas nacionais e a escala local, foram realizadas classificações do SNUC e da PNGATI. Esses agrupamentos foram utilizados para destacar, no conteúdo dessas 
políticas, aspectos possíveis de se observar na realidade, e também para sintetizar seus extensos teores. A classificação de cada política foi realizada a partir de seus objetivos e diretrizes (listados no tópico 2.2). Com base nessas listas foram analisadas as prioridades e as áreas de repercussão comuns a elas. Assim, objetivos e diretrizes foram reunidos em grupos conforme áreas de atuação em comum.

Como pôde ser observado no panorama geral das políticas (tópico 2.2), ambas apresentam bases norteadoras semelhantes. Isso fez com que suas prioridades repercutissem nas mesmas áreas. Por exemplo, existem objetivos e diretrizes previstos para contribuir com a preservação e conservação nas duas políticas, portanto foram reunidos em grupos com a mesma nomenclatura: Preservação e Conservação. Esse modo de análise possibilitou a formação de grupos comuns às duas políticas. Porém, é importante ressaltar que mesmo tendo a mesma área de atuação/contribuição e, portanto o mesmo grupo, cada política possui especificações de objetivo e diretriz diferenciadas. A área de atuação é comum, mas as estratégias - vistas em tais especificidades - são diferentes na perspectiva de cada política e na realidade dos territórios protegidos.

Desse modo, a classificação está apresentada em cinco grupos:

- monitoramento e governança;

- preservação e conservação;

- mitigação de impactos negativos;

- dimensão sociocultural;

- práticas educativas. 


\section{Classificação - Grupos SNUC}

\begin{tabular}{|l|}
\multicolumn{1}{|c|}{ Monitoramento/Governança } \\
\hline $\begin{array}{l}\text { Diversidade Biológica e Recursos Energéticos no território nacional e } \\
\text { nas águas juridicionais }\end{array}$ \\
\hline Desenvolvimento sustentável \\
\hline Recursos hidrícos e edáficos \\
\hline Monitoramento Ambiental \\
\hline Socioeconomia ligada à diversidade biológica \\
\hline Sustentabilidade silvestres \\
\hline Recursos genéricos silvestres \\
\hline $\begin{array}{l}\text { Gestão integrada com as políticas de administração das terras } \\
\text { e águas circundantes }\end{array}$ \\
\hline Alocação adequada dos recursos financeiros \\
\hline
\end{tabular}

\begin{tabular}{|l|}
\hline \multicolumn{1}{|c|}{ Preservação e Conservação } \\
\hline Paisagem de notável beleza cênica \\
\hline Características de natureza geológica, geomorfológica \\
\hline espeleológica, arqueológica, paleontológica e cultural \\
\hline $\begin{array}{l}\text { Proteção de grandes áreas - corredores ecológicos e zonas de } \\
\text { amortecimento }\end{array}$ \\
\hline Amostras significativas do patrimônio biológico \\
\hline
\end{tabular}

Preservação e Mitigação de Impactos Negativos

Espécies ameaçadas de extinção

Ecossistemas naturais / degradados

\begin{tabular}{|l|}
\multicolumn{1}{|c|}{ Dimensão Sociocultural } \\
\hline Importância da sociedade na Política Nacional de Unidades de \\
\hline Conservação \\
\hline $\begin{array}{l}\text { Participação ativa das populações locais na criação, implementação } \\
\text { e gestão UCS }\end{array}$ \\
\hline $\begin{array}{l}\text { Adaptação de métodos e técnias de usos sustentável às } \\
\text { populações locais }\end{array}$ \\
\hline $\begin{array}{l}\text { Garantia de acesso à meios de subsistência às populações no interior } \\
\text { das UCs }\end{array}$ \\
\hline
\end{tabular}

Figura 7 - Classificação de objetivos e diretrizes do SNUC 


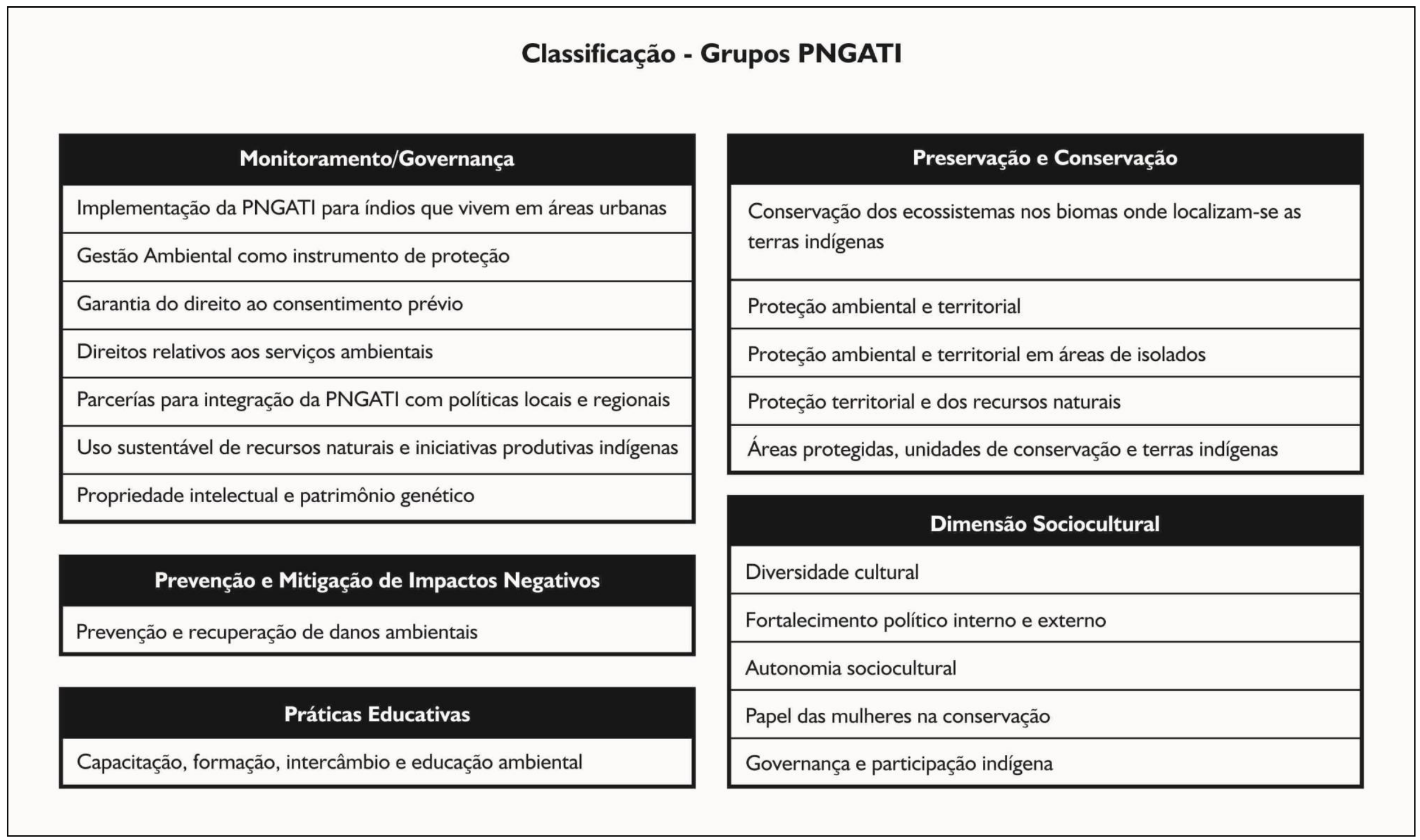

Figura 8 - Classificação dos objetivos e diretrizes da PNGATI 
A referida classificação evidenciou as principais áreas influenciadas pelas políticas públicas aqui estudadas, tais como: educação, preservação, conservação, etc. Nesse contexto, alguns dados foram selecionados para análise empírica da situação de cada uma dessas áreas. O critério para a seleção desses dados foi que eles tivessem relação direta e/ou indireta com os componentes de cada grupo. Com isso, o intuito foi escolher dados cuja análise tenha algum potencial de representação do impacto das diretivas do SNUC e da PNGATI nos territórios protegidos. Assim, a classificação das políticas subsidiou a seleção de tais dados, que nesta conjuntura se inserem como indicadores.

\subsection{INDICADORES SOCIOAMBIENTAIS - TRANSFORMAÇÕES TERRITORIAIS}

O monitoramento é um dos componentes básicos da gestão. No planejamento realizado para gerir determinada área, ou determinado território, é fundamental que se tenha uma estratégia de acompanhamento. Em geral, os diversos setores que trabalham na perspectiva de gestão utilizam indicadores para realizar esse monitoramento. Nesse sentido, indicador pode ser entendido como elemento cuja situação tem potencial de revelar o andamento de determinadas ações, seus resultados e cenários futuros. No sentido geral, indicadores servem para informar o que está acontecendo, como, quando e em qual ritmo.

No âmbito da gestão ambiental, em escala nacional, o MMA trabalha com uma concepção de indicadores que prioriza o caráter científico, quantitativo e de acessibilidade. A partir desse ponto de vista, o Ministério define indicadores ambientais como "estatísticas selecionadas que representam ou resumem alguns aspectos do estado do meio ambiente, dos recursos naturais e de atividades humanas relacionadas." Essa compreensão de indicadores ambientais, e a forma de utilizá-los no monitoramento da gestão pública ambiental tiveram influência das recomendações dos grandes eventos ambientalistas globais. A propósito, como era de se esperar já que a própria estruturação da política ambiental brasileira resulta de respostas a esses movimentos (como explanado no cap.1).

Segundo o Painel de Indicadores Ambientais (PNIA) do MMA, publicado em 2014, o marco inicial do trabalho com tais indicadores teve origem a partir de 
Estocolmo (1972). Quando o evento chamou a atenção mundial para a relação entre ambiente e desenvolvimento, alguns países buscaram incorporar essa reflexão. Na tentativa de acompanhar tal processo, adotaram como indicador de desenvolvimento o resultado da correlação entre PIB e demografia. Assim, iniciou-se o trabalho, em escala global, com indicadores que mais tarde subsidiaria a criação de indicadores mais complexos, envolvendo mais as questões sociais.

Com o socioambientalismo difundido em 1992 durante a ECO92, os indicadores ambientais reaparecem no cenário global, dessa vez mais atrelados à dimensão social da sustentabilidade. Após o evento, o Brasil apresentou a primeira referência consolidada de um painel de indicadores de desenvolvimento sustentável elaborado pelo Instituto Brasileiro de Geografia e Estatística (IBGE). O instituto publica estes dados desde $2002^{26}$ como forma de seguir as orientações da Comissão de Desenvolvimento Sustentável (CDS) da ONU. A partir do referido contexto, os indicadores ambientais, intrinsicamente relacionados ao desenvolvimento sustentável, são utilizados na esfera pública para acompanhar os programas das políticas (MMA, 2014).

Em função desse histórico é comum encontrar, nos componentes de monitoramento da política ambiental, indicadores que refletem mais as condições de desenvolvimento sustentável - em suas proporções globais - do que a dimensão socioambiental em sua complexidade centrada na escala dos territórios. O diferencial, nesse caso, é que o conceito de desenvolvimento sustentável elaborado numa conjuntura global por um determinado segmento da sociedade nem sempre se aplica a realidade socioambiental dos territórios. Por outro lado, os territórios não se isentam dos princípios do desenvolvimento sustentável, pois tais princípios se integraram às práticas capitalistas que interferem direta e/ou indiretamente em seus cotidianos. Diante de tal impasse, é preciso enxergar que, na escala dos territórios, as questões relacionadas ao desenvolvimento sustentável não se excluem, mas também não predominam. Elas se inserem como uma faceta da dimensão socioambiental.

Segundo Stoll-Kleemann (2010 apud ISA), as metodologias mais utilizadas para o

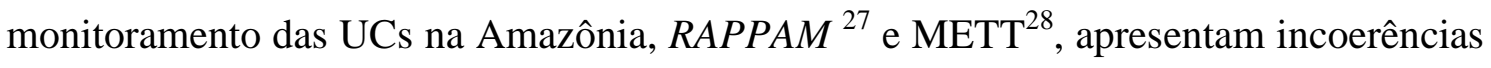
quanto a efetividade, fatores de sucesso e falhas na gestão de áreas protegidas. Segundo

\footnotetext{
${ }^{26}$ A última publicação foi em 2012.

27 Rapid Assessment and Priorization of Protected Area Management (RAPPAM) é um método desenvolvido pela Rede WWF para a avaliação rápida e priorização do manejo em unidades de conservação.

${ }^{28}$ Management Effectiveness Tracking Tool (METT) é uma ferramenta de amonitoramento de efetividade de gestão do Banco Mundial e WWF.
} 
o autor isso acontece porque esses métodos não consideram os fatores locais e também restringem o envolvimento da sociedade, priorizando o papel do Estado. Assim, se tornam pouco atentos aos sistemas socioeconomicos e socioculturais locais (ISA).

No âmbito do terceiro setor existem algumas iniciativas para aprimorar o trabalho com indicadores no sentido de torná-los mais adequados para representar as dinâmicas locais. O Instituto Socioambiental (Isa) criou o Sistema de Indicadores Socioambientais para Unidades de Conservação (Sisuc). A instituição afirma que sua metodologia de avaliação e monitoramento estratégico de UCs

adota conceitos práticos de ciência, tecnologia e sociedade - CT\&S (cf. Hoffmann, 2011), com fins de legitimar debates, valorizar necessidades locais e contribuir na qualificação de processos decisórios de gestão participativa no âmbito dos Conselhos Gestores dessas áreas protegidas. Sob abordagem socioambiental local, a metodologia lança-se no desafio de incorporar conceitos sobre sustentabilidade de sistemas complexos (cf. Bossel, 2001) e interdisciplinaridade para considerar relações entre dimensões e fatores envolvidos na dinâmica de UCs da Amazônia brasileira. Para isso, o SISUC está pautado em princípios como multiplicidade, integrabilidade, complementaridade, comunicabilidade, transparência e continuidade (ISA).

A referida proposta de seleção de indicadores socioambientais é um importante referencial. O esforço para a construção de ferramentas que possam melhorar o monitoramento dos territórios protegidos é fundamental e necessita de embasamentos técnicos como este para se estruturar. Sobretudo no caso das TIs, que ainda não possuem um conjunto consolidado de indicadores adequados ao monitoramento. No caso da PNGATI, o trabalho com indicadores ainda está relacionado ao processo desafio - de implementação da política.

$\mathrm{Na}$ elaboração e desenvolvimento do projeto Gestão Ambiental em Terra Indígenas (Gati), criado para a consolidação da PNGATI, indicadores foram utilizados. A princípio foram úteis para selecionar as primeiras TIs do projeto. Posteriormente, subsidiaram o acompanhamento da gestão dessas terras. As organizações sociais foram importantes na composição dos indicadores trabalhados nesse contexto, tais como iniciativas indígenas e organização de lideranças. No decorrer desse trabalho concluiram que o monitoramento da gestão de TIs pressupõe indicadores socioambientais centrados na realidade local e interação social. Atualmente, Funai, entidades do terceiro setor, organizações indígenas e internacionais estão trabalhando 
para a construção de uma nova ferramenta de monitoramento que atenda tal necessidade (FUNAI).

A construção de indicadores socioambientais proposta nesta pesquisa integra aspectos locais e políticas públicas nacionais, na tentativa de abarcar a dimensão socioambiental dos territórios protegidos. Com isso, a pretensão é ter indicadores que possam refletir a situação da conjuntura que envolve políticas públicas, comunidades locais e conservação. Os elementos de tal conjuntura são subsídios fundamentais para a reflexão sobre a gestão dos territórios. Nesse contexto, é importante ressaltar que tanto o processo histórico quanto a dimensão espacial são fundamentais para a seleção de indicadores e para a análise que eles proporcionam.

$\mathrm{Na}$ escala dos territórios protegidos, é imprescindível considerar a forte influência da gestão e do uso, por estas corresponderem às territorialidades. Trabalhar neste cenário implica lidar com as variações temáticas e escalares próprias de tais territorialidades $^{29}$. Em outras palavras: tanto a gestão quanto o uso, responsáveis pela sustentação do território apresentam dinâmicas váriveis de escala e de tema. A gestão, por exemplo, ocorre em nível de política pública e também em escala local comunitária. Para entender tal dinâmica com o auxílio de indicadores é necessário que estes possam contemplar tais variações, pois dessa maneira, podem evidenciar as transformações territoriais, ressaltando o caráter dinâmico do território.

Em termos práticos, as referidas transformações ocorrem pelo tipo de apropriação e/ou dominação que afeta os territórios, (re)significando-os. Em termos teóricos, fundamentados no conceito de Território Usado, é o uso do território que o faz objeto de análise que se apresenta em constante mudança. Concebendo UCs e TIs como territórios cujo sentido conservacionista é reafirmado pelas suas trajetórias históricas, mecanismos de gestão e usos, o foco de análise das tranformações está direcionado ao sentido conservacionista que eles possam ter estando em sobreposição. Em outras palavras: as transformações territoriais são observadas a partir das territorialidades que podem conferir sentido conservacionista aos territórios.

\footnotetext{
${ }^{29}$ Conforme explanado no capítulo 1 , as territorialidades possuem natureza social centrada nas relações de poder, podendo se apresentar de forma material e/ou imaterial na continuidade dos territórios. Esse caráter social e relacional implica em variações de escala e tema. No caso desta pesquisa, que compreende a gestão e uso do território como suas territorialidades, essas variações se manifestam na escala nacional e local. Ou seja, em cada escala, uso e gestão ocorrem a partir de concepções e temas diferenciados.
} 
O monitoramento realizado na gestão dos territórios protegidos pressupõe indicadores abrangentes que dialoguem com os aspectos locais e com as políticas públicas. Para tal, é necessário ir além da concepção estatística centrada nos sistemas naturais inserindo outros elementos, como os que refletem a influência das territorialidades, ou seja, as consequências de gestão e uso. Essa é a especificidade dos indicadores sociambientais nos termos trabalhados aqui: refletir a dimensão socioambiental considerando as territorialidades. Diante do exposto, têm-se os indicadores socioambientais para mostrar as transformações territoriais.

A fonte de dados para construção dos indicadores é composta por estudos e levantamentos já realizados nos territórios protegidos (detalhados no item 1 dos pressupostos da pesquisa). Nesse conjunto os dados utilizados são secundários, exceto aqueles oriundos do PGTA Jiahui, que resultaram de uma atividade de observação participante. A partir desse referencial, cada indicador foi selecionado com base em sua relação com os componentes de cada grupo, por isso dialogam direta ou indiretamente com eles, sendo da PNGATI e/ou do SNUC. Por exemplo, o indicador PPBIO relacionado ao grupo monitoramento e governança irá dialogar com os componentes deste grupo estando estes no grupo do SNUC e/ou da PNGATI. Conforme detalhado abaixo (Tabela9).

\begin{tabular}{|c|c|c|c|c|c|}
\hline \multicolumn{6}{|c|}{ Grupos das políticas e seus indicadores } \\
\hline $\begin{array}{l}\text { Grupo de } \\
\text { Política } \\
\text { Pública } \\
\text { SNUC e } \\
\text { PNGATI }\end{array}$ & $\begin{array}{l}\text { Monitoramento } \\
\text { e governança }\end{array}$ & $\begin{array}{l}\text { Preservação e } \\
\text { conservação }\end{array}$ & $\begin{array}{l}\text { Prevenção } \\
\text { e mitigação } \\
\text { de impactos } \\
\text { negativos }\end{array}$ & $\begin{array}{l}\text { Dimensão } \\
\text { sociocultural }\end{array}$ & $\begin{array}{l}\text { Práticas } \\
\text { educativas }\end{array}$ \\
\hline $\begin{array}{l}\text { Indicadores } \\
\text { Selecionados }\end{array}$ & $\begin{array}{l}\text { PPBIO } \\
\text { Instrumentos } \\
\text { de Gestão } \\
\text { Projetos e } \\
\text { iniciativas de } \\
\text { gestão integrada }\end{array}$ & $\begin{array}{l}\text { Desmatamento } \\
\text { Presença de } \\
\text { espécies-chave } \\
\text { Acordos de uso } \\
\text { nas áreas }\end{array}$ & $\begin{array}{l}\text { Incremento } \\
\text { Desmatamento } \\
\text { Número de } \\
\text { espécies em } \\
\text { extinção }\end{array}$ & $\begin{array}{l}\text { AAI Mulheres } \\
\text { Projetos/ } \\
\text { Atividades } \\
\text { dos moradores } \\
\text { da Flona } \\
\text { Programas } \\
\text { PGTA Jiahui }\end{array}$ & $\begin{array}{l}\text { Capacitações } \\
\text { Atividades } \\
\text { de educação } \\
\text { ambiental }\end{array}$ \\
\hline
\end{tabular}

Tabela 9 - Indicadores Socioambientais dos territórios protegidos

É importante ressaltar que os indicadores selecionados dentre os instrumentos de gestão, principalmente o Etnozoneamento e o Zoneamento, são os próprios indicadores (ter desenvolvido essas ferramentas já é um indicativo) e ao mesmo tempo referência espacial e de conteúdo para observação dos demais indicadores. A apresentação dos 
indicadores selecionados, incluindo a especificação de seus elementos correspondentes nos grupos das políticas públicas, segue no próximo tópico e a análise destes no capítulo 3.

\subsubsection{Monitoramento/Governança}

\subsubsection{PPBIO}

O Programa de Pesquisa em Biodiversidade (PPBIO) foi criado em 2004 e está vinculado ao Instituto Nacional de Pesquisas da Amazônia (INPA) do Ministério da Ciência, Tecnologia e Informação (MCTI). O objetivo do programa é intensificar estudos sobre biodiversidade no Brasil, descentralizar a produção científica, integrar atividades de pesquisa e divulgar os resultados para diferentes finalidades, como gestão ambiental e educação. As pesquisas são desenvolvidas em 12 Núcleos Regionais (NR), localizados no Acre, Amazonas, Amapá, Pará, Mato Grosso e Roraima.

As atividades do PPBIO envolvem capacitações, projetos de extensão e disponibilização de dados acerca da biodiversidade do bioma Amazônia. Essas pesquisas estão em sintonia com os objetivos dos territórios protegidos e por isso podem contribuir para sua gestão. As atividades do PPBIO dialogam diretamente com o item "monitoramento ambiental" do grupo Monitoramento/Governança (SNUC). Além disso, as ações do programa influenciam indiretamente questões relacionadas a "gestão ambiental como instrumento de proteção" (PNGATI) e "diversidade biológica e recursos energéticos" (SNUC), componentes do mesmo grupo.

Desse modo, a presença de um NR nas proximidades dos territórios protegidos é um indicador de transformação territorial. Isso porque suas ações se inserem como um tipo de apropriação do território com potencial de transformação por meio da produção e difusão de conhecimento acerca da Amazônia, potencializando o sentido conservacionista. Sua estratégia de organização em NR se aproxima da escala local, subsidiando o monitoramento ambiental necessário à conservação.

\subsubsection{Instrumentos de gestão}

Os instrumentos de gestão previstos na PNGATI (Etnomapeamento e Etnozoneamento) e no SNUC (Plano de Manejo/Zoneamento) são utilizados para planejar o uso dos recursos naturais, elaborar projetos socioeconômicos e desenvolver 
estratégias de proteção territorial. Estes cumprem também um papel político, subsidiando a articulação com instituições públicas (Funai, MMA, MDS, etc.) e possíveis parceiros da sociedade civil (empresas, ONGs, etc.). As comunidades indígenas e demais povos da floresta realizam ainda outros estudos que também desempenham as referidas funções, como o Plano de Proteção Territorial, Plano de Gestão Territorial e Ambiental (PGTA), Diagnóstico Etnoambiental Participativo (DEAP), Biomonitoramento, entre outros. Diante de sua importância para os territórios protegidos essas ferramentas de gestão foram elencadas como indicadores que dialogam diretamente com o componente de "gestão ambiental como instrumento de proteção" (PNGATI) e "socioeconomia ligada à diversidade biológica" (SNUC).

O planejamento estratégico registrado em tais projetos representa o tipo de apropriação e usos dos territórios, evidenciando aspectos importantes da dinâmica territorial como suas prioridades, objetivos e conflitos. Tais registros revelam as transformações territoriais que ocorrem por meio das estratégias de gestão e pela realidade enfrentada em tal exercício de planejamento. Os instrumentos de gestão elencados como indicadores na TI Jiahui foram: Etnomapeamento, Etnozoneamento, Biomonitoramento e PGTA. Na perspectiva da Flona de Humaitá foram selecionados o Plano de Manejo e Zoneamento.

\subsubsection{Projetos e iniciativas de gestão integrada e compartilhada}

Além dos instrumentos de gestão existem também projetos voltados para formas de gestão específicas, como a gestão integrada e a compartilhada. O primeiro caso trata de UCs da mesma região, os chamados mosaicos de áreas protegidas. Nesses casos, Conforme Art. 26 da Lei do SNUC,

[...] a gestão do conjunto deverá ser feita de forma integrada e participativa, considerando-se os seus distintos objetivos de conservação, de forma a compatibilizar a presença da biodiversidade, a valorização da sociodiversidade e o Desenvolvimento Sustentável no contexto regional. (BRASIL, 2002) 
O desenvolvimento desse tipo projeto contribui para a conservação dos ecossistemas, cujos territórios extrapolam os limites das UCs, e ainda fortalecem as articulações entre os moradores dos mosaicos.

No caso da gestão compartilhada, trata-se da possibilidade de instituições do terceiro setor serem responsáveis pela gestão de uma determinada UC. Conforme Art.30 da referida Lei, "As unidades de conservação podem ser geridas por organizações da sociedade civil de interesse público com objetivos afins aos da unidade, mediante instrumento a ser firmado com o órgão responsável por sua gestão". A presença de Organizações Sociais de Interesse Público (OSCIPs) na gestão das UCs muda, em alguma medida, o papel do Estado nas relações de poder, o que pode alterar o entendimento acerca das territorialidades apresentado até aqui.

Assim, essas formas de gestão revelam transformações territoriais resultantes das práticas estratégicas de gestão e sustentação dos territórios. Estando, portanto, no campo das territorialidades relacionadas à gestão. Por esse motivo, projetos e iniciativas de gestão integrada são indicadores diretamente relacionados à situação da componente "gestão integrada com as políticas de administração das terras e águas circundantes" (SNUC) e indiretamente ao "desenvolvimento sustentável” (SNUC).

\subsubsection{Preservação e Conservação}

\subsubsection{Desmatamento}

O sentido conservacionista dos territórios protegidos aqui abordados pressupõe a possibilidade de acesso direto aos elementos da paisagem - cursos d'água, solos, cobertura vegetal, etc. Tais elementos fazem parte de um sistema, ou seja, impactos negativos sobre um traz consequências para todo o resto. Nesse conjunto, a cobertura vegetal é fundamental para o equilíbrio sistêmico. Para monitorar os impactos dessas atividades sobre a vegetação, subsidiando assim medidas preventivas e mitigadoras, entidades do terceiro setor, como o Instituto do Homem e Meio Ambiente da Amazônia (IMAZON), e órgãos públicos como o Instituto Nacional de Pesquisas Espaciais (INPE), desenvolvem projetos de monitoramento da cobertura vegetal por imagens de satélite. A partir dos resultados desses projetos os índices de desmatamento na Amazônia Brasileira são constantemente divulgados.

A perda de vegetação de forma maciça pode se dar em função de atividades agropecuárias, retirada de madeira, urbanização etc. A cobertura florestal também pode 
se transformar a partir de atividades de manejo e agricultura familiar dando lugar a outros tipos de vegetação. Portanto, os índices de desmatamento têm potencial para revelar os tipos de uso de uma determinada área. No caso dos territórios protegidos isso tem a ver os tipos de atividades realizadas em áreas destinadas a conservação, o que pode interferir no sentido conservacionista, transformando o território.

Os índices de desmatamento estão diretamente relacionados à realidade dos componentes de "conservação dos ecossistemas nos biomas onde localizam-se as terras indígenas" e "proteção territorial e dos recursos naturais" (PNGATI). E indiretamente relacionados à "proteção de grandes áreas - corredores ecológicos e zonas de amortecimento" (SNUC).

\subsubsection{Presença de espécies-chave}

No âmbito da ecologia, o conceito de espécie-chave se caracteriza pela sua capacidade de impactar o meio. Paine (1966) as definiu como espécies capazes de causar grande alteração nas comunidades quando suas populações são aumentadas ou reduzidas, com efeito de cascata ao longo da cadeia trófica. $\mathrm{Na}$ etnoecologia, para melhor compreender as relações entre populações humanas e essas espécies, recentemente alguns autores começaram a utilizar o termo espécie-chave cultural. Nesse conceito são inseridos o uso e a importância dessas espécies para as comunidades.

A presença de espécies-chave, observada pela perspectiva do uso, é fator com potencial de evidenciar aspectos de costumes e ao mesmo tempo níveis de conservação da fauna. Ambos são elementos da dinâmica territorial que podem variar impactando, ou não, o sentido conservacionista. Concebida como indicador está relacionada ao componente de "amostras significativas do patrimônio biológico" (SNUC), “características de natureza geológica, geomorfológica, espeleológica, arqueológica, paleontológica e cultural" (SNUC), e "proteção aos saberes tradicionais" (PNGATI). 


\subsubsection{Acordos de uso nas áreas de sobreposição}

Nas áreas de sobreposição entre territórios protegidos a legislação prevê a gestão seja feita de forma participativa e integrada, indica ainda que os órgãos responsáveis formem Grupos de Trabalho (GTs) para regularizar as sobreposições entre UCs e TIs. Acordos de gestão são importantes para compatibilizar os usos praticados nas áreas de sobreposição. Possíveis conflitos nessas áreas podem culminar em degradação socioambiental, afetando diretamente o sentido conservacionista dos territórios. Por esse motivo, tais acordos e seus principais pontos foram elencados como indicadores relacionados à realidade e variações de "proteção ambiental e territorial” (PNGATI).

\subsubsection{Prevenção e Mitigação de Impactos Negativos}

\subsubsection{Incremento desmatamento}

As taxas de incremento de desmatamento mostram quantitativamente a evolução deste processo. Em tal cálculo, o foco é a análise comparativa do crescimento e/ou contenção de áreas já desflorestadas em diferentes períodos. Considerando-se a já mencionada importância da floresta para a conservação socioambiental (2.3.2), observar o quanto o desmatamento impacta as áreas pode responder sobre a efetividade das ações de prevenção e mitigação dos impactos negativos causados pela perda da cobertura vegetal. As taxas de incremento de desmatamento podem subsidiar o monitoramento das medidas mitigadoras desse problema. A transformação territorial evidenciada, neste caso, está relacionada a intervenções realizadas para evitar e mitigar as consequências do desmatamento. Este indicador dialoga com o componente de "ecossistemas naturais degradados" (SNUC) e prevenção e recuperação de danos ambientais (PNGATI). 


\title{
2.4.3.2. Número de espécies em extinção
}

O desaparecimento de algumas espécies faz parte de um processo natural e podem estar relacionadas ao surgimento de competidores ou diferenciação genética. No entanto, as ações antrópicas se transformaram no principal agente de extinção, o que acelerou todo o processo. Segundo texto publicado no site do Ministério do Meio Ambiente (MMA),

\begin{abstract}
Atualmente, as principais causas de extinção são a degradação e a fragmentação de ambientes naturais, resultado da abertura de grandes áreas para implantação de pastagens ou agricultura convencional, extrativismo desordenado, expansão urbana, ampliação da malha viária, poluição, incêndios florestais, formação de lagos para hidrelétricas e mineração de superfície. Estes fatores reduzem o total de habitats disponíveis às espécies e aumentam o grau de isolamento entre suas populações, diminuindo o fluxo gênico entre estas, o que pode acarretar perdas de variabilidade genética e, eventualmente, a extinção de espécies (MMA).
\end{abstract}

Adotar a extinção de espécies como indicador tem o objetivo de evidenciar possíveis alterações na fauna e flora local. Tendo em vista a interdependência entre animais, cobertura vegetal e comunidades locais, o desaparecimento de determinadas espécies impacta diretamente a conservação socioambiental dos territórios protegidos. Nesse sentido, as espécies em extinção podem revelar uma transformação territorial na qual a conservação é afetada de maneira sistêmica, a partir de elementos específicos. O diálogo aqui é estabelecido com o componente "espécies ameaçadas de extinção" (SNUC).

\subsubsection{Dimensão Sociocultural}

\subsubsection{AAI Mulheres}

A importância do papel das mulheres no contexto de proteção, conservação e gestão de terras indígenas é previsto pela PNGATI. De acordo com o decreto é importante promover a participação de homens e mulheres, de forma igualitária, na governança das terras. Esta questão de gênero faz parte dos elementos da dimensão sociocultural existente nas duas políticas, mas é abordada diretamente apenas pela PNGATI. No contexto das iniciativas indígenas a capacitação de Agentes Ambientais Indígenas (AAI) foi utilizada para observar a situação dessa diretriz. O número de 
mulheres capacitadas como AAI representa fortalecimento das comunidades por mais pessoas atuantes na proteção do território. Isso mostra uma transformação territorial caracterizada pela valorização do papel de cada um nas aldeias. Este indicador dialoga com o componente "papel das mulheres na conservação" (PNGATI).

\subsubsection{Projetos e atividades dos moradores da FLONA}

Nas UCs de uso sustentável, como a Flona de Humaitá, as atividades produtivas estão diretamente relacionadas ao sentido desse tipo área protegida. As técnicas de manejo dos recursos naturais, desenvolvidas em tais atividades, viabilizam a subsistência das comunidades e a conservação da natureza no mesmo processo. Neste contexto, os projetos e as atividades produtivas dos moradores e moradoras da Flona são importantes indicadores relacionados à sustentabilidade e consequentemente ao sentido conservacionista da UC. Este indicador tem potencial de subsidiar a análise sobre a repercussão das diretrizes socioculturais e dialoga com o componente "garantia de acesso aos meios de subsistência às populações no interior das UCs".

\subsubsection{Programas do Plano de Gestão Territorial e Ambiental (PGTA) da TI Jiahui (Observação Participante)}

Os PGTA's de TIs são ferramentas basilares para gestão desses territórios, pois neste documento as comunidades indígenas registram o planejamento para o uso de suas terras. Com base em suas prioridades e utilizando informações compiladas durante outros estudos, como o Diagnóstico Etnoambiental e Plano de Proteção, por exemplo, as comunidades traçam estratégias voltadas para a proteção e desenvolvimento territorial. Desse modo, o PGTA é para a TI o que o Plano de Manejo é para as UCs. Apesar disso, sua elaboração e implementação não estão previstos na PNGATI. No contexto da referida política, o Etnozoneamento e o Etnomapeamento são as ferramentas para se atingir a gestão.

Apesar da importância desses mapas, eles vêm se mostrando insuficientes para as demandas de gestão. Conforme constatado por Machado (2014, p.92), a partir da perspectiva dos indígenas da TI Trombetas Mapuera e Nhamundá Mapuera, o mapa cultural é utilizado mais como uma ferramenta de diagnóstico do que de gestão propriamente dita. Correia (2007) ao estudar o Etnozoneamento das TIs do Acre, compreendeu que se trata de um instrumento de planejamento - o qual ele chamou de 
"saber-poder"- e de empoderamento dos indígenas. Com base nos referidos estudos infere-se que o diagnóstico e o planejamento realizado com auxilio dessas duas ferramentas são etapas importantes da gestão, mas precisam de estratégias de ação para viabilizar a aplicabilidade de seus conteúdos.

Em 2013, um ano após a publicação da PNGATI, a Funai lançou uma cartilha reconhecendo a importância dos PGTAs para as TIs e estabelecendo direcionamentos para elaboração e implementação desses documentos. Segundo o órgão indigenista "os PGTAs previstos no Plano Plurianual do Governo Federal (PPA 2012 - 2015) [...] despontam como instrumentos de diálogo intercultural e de planejamento para a gestão territorial e ambiental de terras indígenas brasileiras" (FUNAI, 2013).

Nesse contexto, os programas do PGTA da TI Jiahui foram considerados importantes indicadores, tanto pela sua própria elaboração, que demonstra a articulação da comunidade, quanto para fonte de dados e informações sobre os aspectos de gestão em escala local. Ao se reunirem para refletir, dialogar e traçar estratégias para a gestão do território, as questões prioritárias foram colocadas em programas específicos. Dessa maneira os programas refletem o que os (as) indígenas entendem por gestão e como pensam em colocá-la em prática. Durante este exercício, a dinâmica territorial é evidenciada em vários aspectos por meio da reflexão sobre acontecimentos históricos, questões atuais e projeções para o futuro. Nisto consiste a transformação territorial embasada nos diversos usos que o povo Jiahui realiza por meio da apropriação do território.

O PGTA Jiahui contem estratégias traçadas para 40 anos, durante os quais deverão ser realizadas atividades dos cinco programas destinados à proteção territorial, fortalecimento institucional, educação/saúde, alternativas econômicas/produção e comunicação. Cada programa foi composto por objetivos geral e específico, resultados esperados, atividades, instituições responsáveis e apoiadoras e indicadores. 


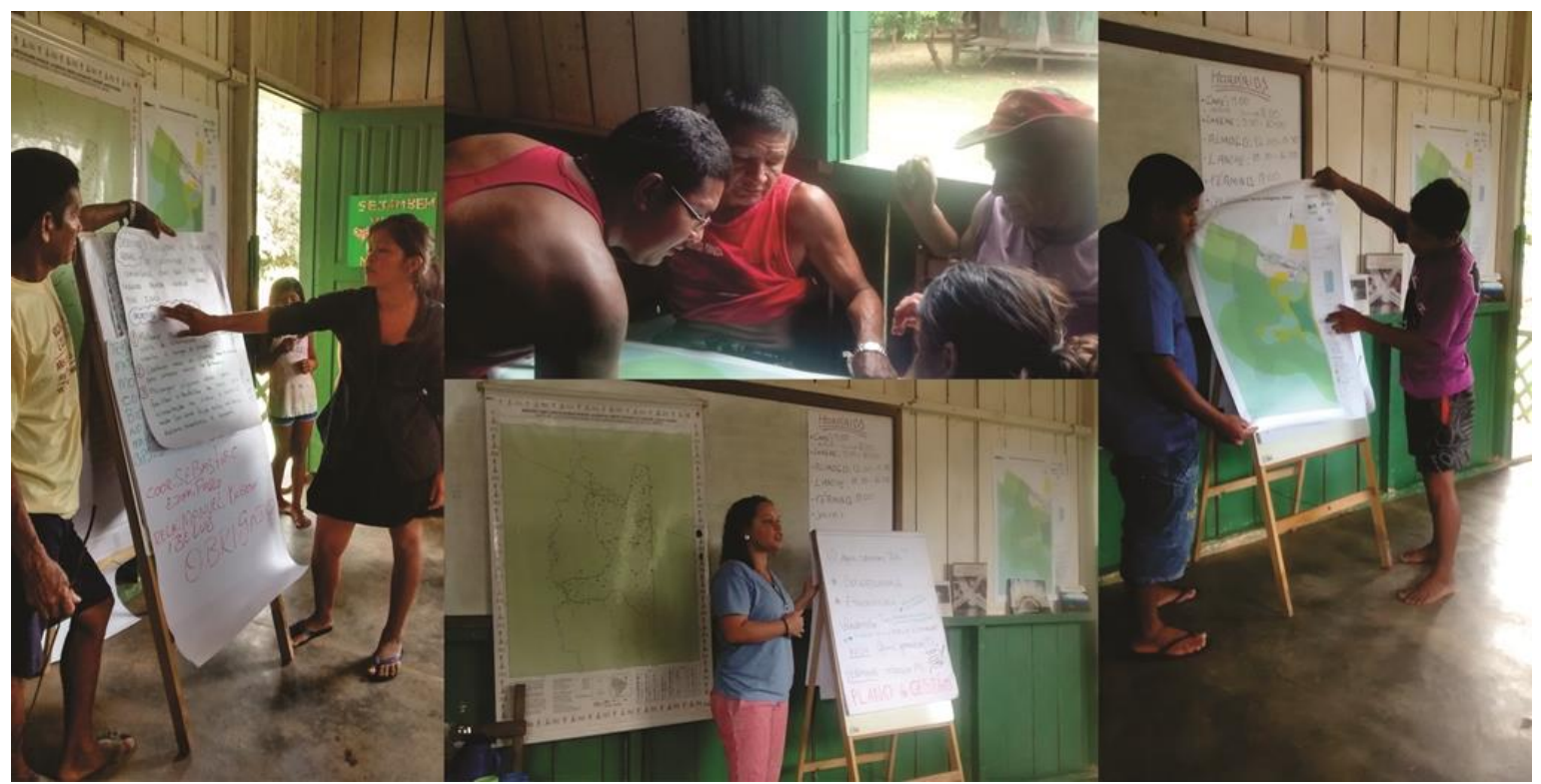

Figura 9 - Oficina de elaboração do PGTA Jiahui. Fonte: APIJ, 2014.

Os programas do PGTA Jiahui dialogam diretamente com os componentes "fotalecimento político interno e externo", "governança e participação indígena" e "autonomia sociocultural" (PNGATI). A elaboração deste planejamento dialoga também com o componente "importância das populações tradicionais" (SNUC).

\subsubsection{Práticas Educativas}

\subsubsection{Capacitações}

As capacitações são atividades de aprendizagem que proporcionam acesso a diversos tipos de conhecimento. A difusão de saberes contribui para a conservação, contemplando práticas conservacionistas e desenvolvimento das capacidades humanas. Conforme as atividades já desenvolvidas pelas pessoas no interior dos territórios protegidos, as demandas por novos conhecimentos e troca de saberes podem surgir fortalecendo assim ações favoráveis à gestão socioambiental. As capacitações realizadas nos territórios fazem parte da dinâmica territorial, revelando quais são as prioridades do momento para aqueles que ali vivem, e para demais envolvidos. Esse indicador dialoga com o componente "capacitação, formação, intercâmbio e educação ambiental" (PNGATI). 


\title{
2.4.5.2. Atividades de Educação Ambiental
}

A Política Nacional de Educação ambiental está amparada no seguinte conceito:

\begin{abstract}
Entendem-se por educação ambiental os processos por meio dos quais o indivíduo e a coletividade constroem valores sociais, conhecimentos, habilidades, atitudes e competências voltadas para a conservação do meio ambiente, bem de uso comum do povo, essencial à sadia qualidade de vida e sua sustentabilidade (BRASIL, 1999)
\end{abstract}

Nos termos da Política Nacional trata-se de um conceito aplicado a educação nacional em todos os níveis. Na consolidação de tal perspectiva as UCs têm um papel importante, pois proporcionam experiências voltadas especificamente à relação sociedade e natureza. Nas TIs a essência da Educação Ambiental já faz parte da dinâmica territorial histórica. Mas devido a atual situação de pressões externas e problemas internos de gestão, desenvolver atividades específicas para formação em aspectos socioambientais pode contribuir para a conservação.

A Educação Ambiental, no contexto dos territórios protegidos, deve ser entendida por uma perspectiva ampla, além das atividades escolares. O espaço destinado às atividades de Educação Ambiental é amplo e abrange os espaços de vivência das pessoas. Para além da escola, onde as atividades são geralmente voltadas para crianças e jovens em idade escolar, a comunidade também é espaço para as práticas de aprendizagem sobre a relação sociedade e natureza. Nos Territórios Protegidos esse processo ocorre por meio da reflexão, percepção e pertencimento cotidiano das pessoas em relação ao ambiente (ALVES\&OLIVEIRA, 2008).

Com base no exposto, as atividades de Educação Ambiental foram selecionadas como indicadores por representar um importante elemento para construção de cenários futuros favoráveis à conservação. A transformação territorial aqui se insere num contexto de atitudes que promovem um olhar específico para a dimensão socioambiental e que promove mudanças futuras. Esse indicador dialoga com o componente "capacitação, formação, intercâmbio e educação ambiental” (PNGATI) e "educação e interpretação ambiental - turismo ecológico" (SNUC). 


\section{CAPÍTULO III. ANÁLISE DAS TRANSFORMAÇÕES TERRITORIAIS}

O terceiro capítulo traz a análise dos indicadores socioambientais e as transformações territoriais que estes revelaram. O pensamento norteador de tal análise se fundamenta na relação entre os pressupostos teóricos do Território Usado e a dinâmica territorial. Assim, apresentam-se resultados que evidenciam como a teoria pode encontrar correspondência na leitura da realidade. Neste caso, o uso do território, como categoria de análise, encontra correspondência nas transformações territoriais analisadas neste capítulo.

Em tal análise estão representadas as escalas nacional e local. Isso porque as diretrizes e objetivos das políticas ambiental e indigenista direcionaram a seleção dos indicadores utilizados na observação das transformações territoriais em escala local. Desse modo, apresenta-se os resultados da análise dos 16 indicadores $^{30}$ que resultaram da classificação da PNGATI e do SNUC, e são o resultado da correlação entre referencial empírico e teórico aplicada às escalas local e nacional.

\subsection{MONITORAMENTO E GOVERNANÇA}

\subsubsection{Instrumentos de Gestão (Indicadores Referência)}

$\mathrm{Na}$ TI Jiahui vários foram os estudos sobre o território que proporcionaram a atual base de planejamento da comunidade. Estes trabalhos tiveram a função de instrumentalizar a comunidade no processo de tomada de decisão sobre seus recursos e necessidades. Outro aspecto relevante é que, por retratarem aspectos da realidade local, estes trabalhos são importantes subsídios para direcionar o diálogo sobre a política indigenista. A existência de tais estudos demonstra o potencial de gestão socioambiental dos territórios protegidos, pois equipam as comunidades no exercício de suas territorialidades e fundamentam o processo de elaboração de políticas públicas. São portanto, instrumentos de gestão.

\footnotetext{
${ }^{30}$ Após compilação dos instrumentos de gestão presentes nos territórios protegidos, tornou-se evidente a necessidade de destacar dois deles: o Etnozoneamento e o Mapa de Usos da Flona. Isso por representarem uma referência espacial para os demais indicadores e também por serem centrais na estrutura metodológica proposta.
} 
Os estudos desenvolvidos pelos Jiahui até dezembro de 2014 incluem: PGTA, Etnomapeamento, Etnozoneamento, Diagnóstico Etnoambiental Participativo (DEAP), Plano de Proteção Territorial (PPT), Biomonitoramento, dentre outros. Diante dessa informação pode-se inferir que em termos de instrumentos de gestão a TI Jiahui está bem equipada. O fato de tê-los é um indicativo do nível de articulação local e autonomia indígena na gestão do território. A TI Jiahui possui os dois instrumentos previstos na PNGATI e o PGTA além de outros de iniciativa própria ${ }^{31}$.

O principal instrumento de gestão de UCs é o Plano de Manejo (PM) centrado principalmente no Zoneamento. No caso da Flona de Humaitá os estudos de diagnósticos que fundamentam o PM foram realizados, mas a publicação destes ainda não ocorreu conforme previsto. Considerando as diretrizes da Lei do SNUC, a ausência deste instrumento de gestão, dezoito anos após a criação da UC, é um fator problemático para o cumprimento de seu objetivo conservacionista. Apesar de não ter o Zoneamento, fundamental para a gestão da Flona e também para a metodologia aqui proposta, existe um estudo sobre uso e apropriação, cujo conteúdo certamente norteará o PM.

Dentre os projetos desenvolvidos como ferramentas de gestão nos territórios protegidos, foram selecionados para subsidiar a análise $^{32}$ : Etnozoneamento; Biomonitoramento; PGTA; Levantamento Socioeconômico da Flona de Humaitá e projeto Fonteiras Florestais. Os três primeiros foram realizados pela comunidade Jiahui, e seus parceiros, os últimos na Flona de Humaitá. A escolha dessas ferramentas foi baseada na importância de seus temas. O Etnozoneamento é um direcionador dos usos, o Biomonitoramento é uma ferramenta de acompanhamento da biodiversade e o PGTA é um documento de planejamento. Estas fases fecham o ciclo de gestão da TI. O Projeto Fronteiras Florestais foi selecionado por apresentar os tipos de uso no interior da Flona, retratando a dinâmica local que certamente estará representada no Zoneamento, quando for publicado.

A simples existência dos instrumentos de gestão são indicadores de transformações territoriais. A elaboração de pesquisas e planejamentos pelos atores locais é uma conquista diante dos entraves econômicos, políticos e culturais enfrentados

\footnotetext{
${ }^{31}$ A Associação do Povo Indígena Jiahui (APIJ) possui aproximadamente sete projetos em busca de apoio para implementação. Os planos de desenvolvimento da comunidade estão relacionados à cultura, infraestrutura, capacitação, proteção territorial, produção e geração de renda (APIJ, 2014).

${ }^{32}$ A simples presença dos projetos já é indicador de potencial para gestão socioambiental, mas dentre eles foi relevante selecionar alguns cujos dados são estratégicos para subsidiar a análise.
} 
por populações tradicionais. Os instrumentos evidenciam os esforços realizados para contribuir com a gestão local em consonância com as políticas públicas. Com base na observação desse primeiro indicador pode-se afirmar que a TI cumpriu as diretivas da política nacional, já a Flona ainda não consolidou seu principal instrumento de gestão previsto em Lei.

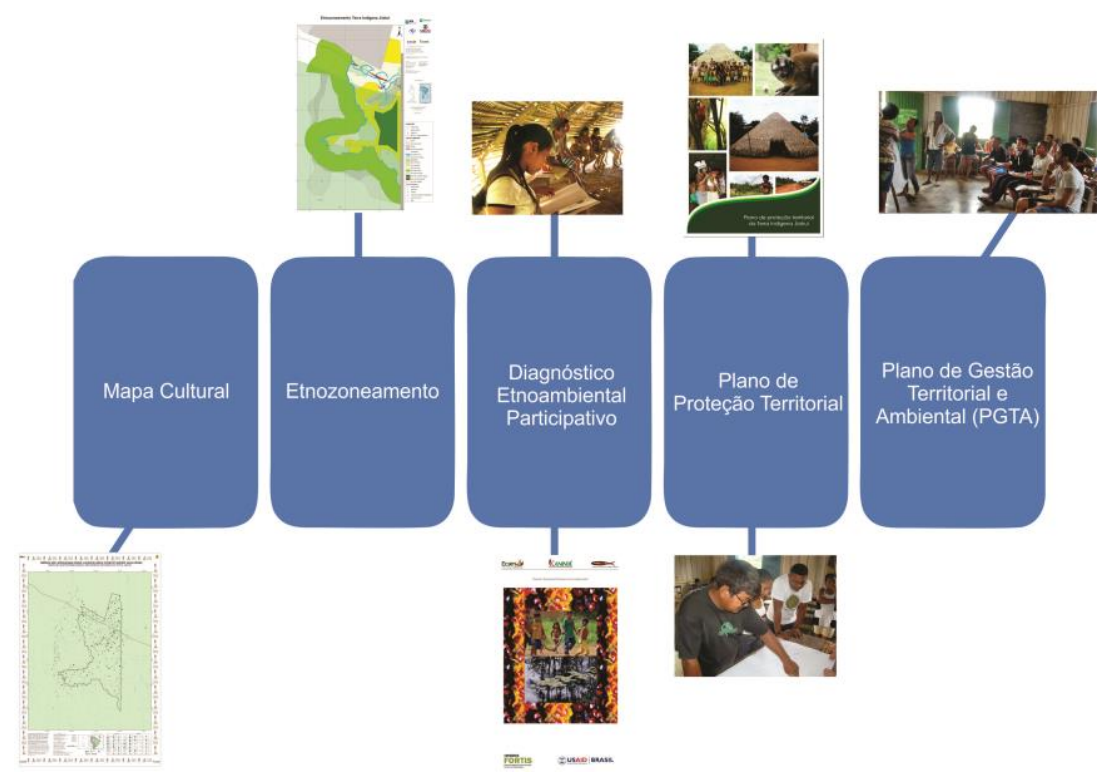

Figura 10 - Alguns projetos do Povo Indígena Jiahui

A transformação territorial aqui evidenciada diz respeito às estratégias de gestão, em especial às condições de elaboração e implementação destas. $\mathrm{O}$ conhecimento do território tem sido utilizado no enfrentamento dos entraves e no fortalecimento dos potenciais de gestão local. Os estudos diagnósticos fundamentam o planejamento dos recursos e registram as especificidades e demandas locais. A apropriação dessas ferramentas possibilita que as pautas comunitárias, relacionadas ao uso dos territórios, tenham representatividade. $\mathrm{O}$ conhecimento dos aspectos socioambientais permite ainda a identificação dos possíveis respaldos para demandas específicas. Portanto, a estratégia de gestão local é desenvolvida no contexto de estudo, registro e divulgação da realidade dos territórios.

A implementação desses instrumentos, ou seja, a realização das ações previstas nos planejamentos pressupõe o amparo do Estado e a articulação comunitária, pois envolve o despendimento de recursos humanos e financeiros. Na TI Jiahui existe uma consistente disponibilidade de instrumentos de gestão que apontam as necessidades 
específicas do Território. Porém, para que possam ser supridas é preciso apoio das instituições estatais no cumprimento de suas obrigações constitucionais.

Na Flona o estágio de gestão é diferente. A ausência do PM, fundamental instrumento de gestão, indica que a principal demanda ainda é pela elaboração, formalização e divulgação dos instrumentos de gestão. Desse modo, a implementação será uma etapa futura. O principal impacto dessa lacuna, do ponto de vista do uso, é o entrave à formalização das atividades produtivas locais. Ter as zonas de extrativismo e agricultura familiar previstas no Zoneamento embasa a elaboração dos projetos das associações, facilitando o acesso das comunidades às políticas específicas, como o crédito rural. O PM é uma importante referência para a questão fundiária nas UCs de Uso Sustentável. Para o modo de vida das comunidades moradoras da Flona, o instrumento de gestão previsto na Lei do SNUC é fundamental, uma vez que a criação da UC impôs regras de uso que interferem em suas atividades produtivas.

Cabe ressaltar ainda que os instrumentos de gestão, especialmente aqueles selecionados para subsidiar a análise, são referência de conteúdo para observação dos demais indicadores elencados. Isso porque são estudos de diagnósticos e de planejamento que revelam dados primários dos territórios protegidos. Neste contexto, o Etnozoneamento e o Mapa de Uso da Flona se destacaram como referências espaciais de análise e por isso são analisados em suas estruturas de elaboração.

\subsubsection{Etnozoneamento da TI Jiahui}

A história da cartografia revela que os mapas foram amplamente utilizados pelas sociedades para subsidiar e representar disputas territoriais. Nesse contexto, as técnicas de mapeamento se inseriram como privilégios de grupos hegemônicos no decorrer dos tempos. Tal situação pode ser observada na trajetória da cartografia do Acre, sobre a qual Correia (2007) afirma que

ao longo dos séculos os mapas foram produzidos e utilizados por grupos dominantes como componentes intrínsecos de processos de conquista territorial e social. Isso fica visível na história da cartografia acreana que produziu diversos mapas para a delimitação das fronteiras internacionais e estaduais. Apenas recentemente, o amplo 
conhecimento dos povos indígenas que habitam a região passou a ser contemplado nos mapas (CORREIA, op cit, p.22).

Atualmente existe a possibilidade de acesso e democratização das técnicas de mapeamento, o que proporciona uma cartografia mais diversa. Quando o referido autor menciona a inserção dos conhecimentos indígenas nos mapas como um dos elementos de transformação da cartografia, Machado (2014, p.11) concorda e atribui esse fato à "inserção de novas tecnologias e novos olhares sobre os povos indígenas". Nesse sentido, o Etnozoneamento se consolidou nas TIs como uma ferramenta de planejamento, empoderamento e representatividade indígena.

Do ponto de vista técnico, o Etnozoneamento consiste na elaboração de um mapa temático contendo as áreas diferenciadas (zonas) conforme uso. Para definí-las as comunidades têm como referência as informações do Diagnóstico Entoambiental Participativo (DEAP) - estudo que sintetiza a situação socioambiental da TI. Após a definição das zonas, os indígenas determinam regras de uso específicas para cada uma. $\mathrm{O}$ objetivo é garantir usos adequados às características naturais e que atendam os objetivos da comunidade, tais como subsistência, conservação, proteção, etc. Esse mapeamento é realizado durante oficina colaborativa com a participação da comunidade e equipe técnica multidisciplinar (ACT Brasil, 2010). O Etnozoneamento da TI Jiahui foi realizado em 2011 (Figura 11) e revisado em 2014 (Figura12). 


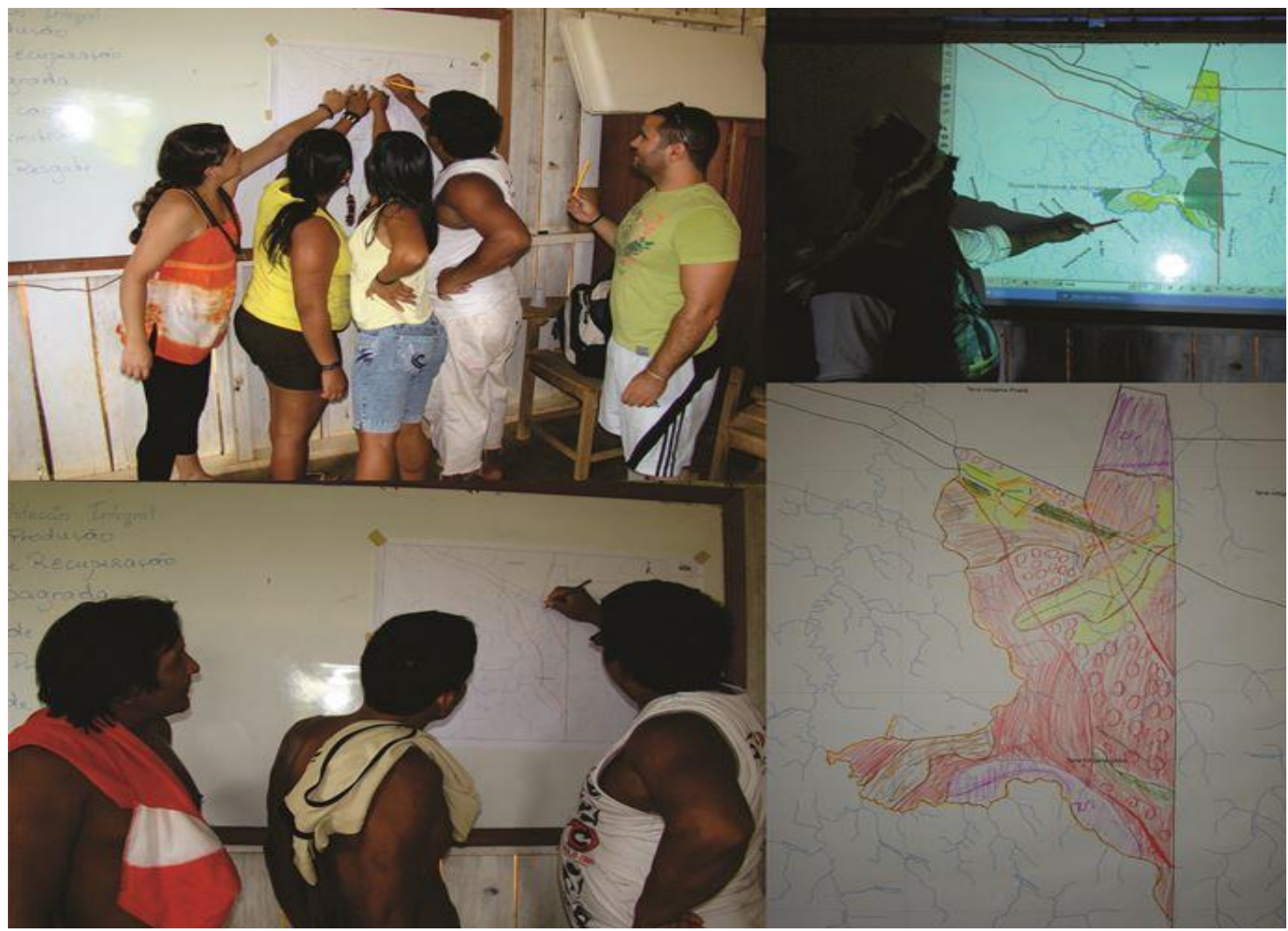

Figura 11 - Oficina de elaboração do Etnozoneamento da TI Jiahui. Fonte: APIJ,2011

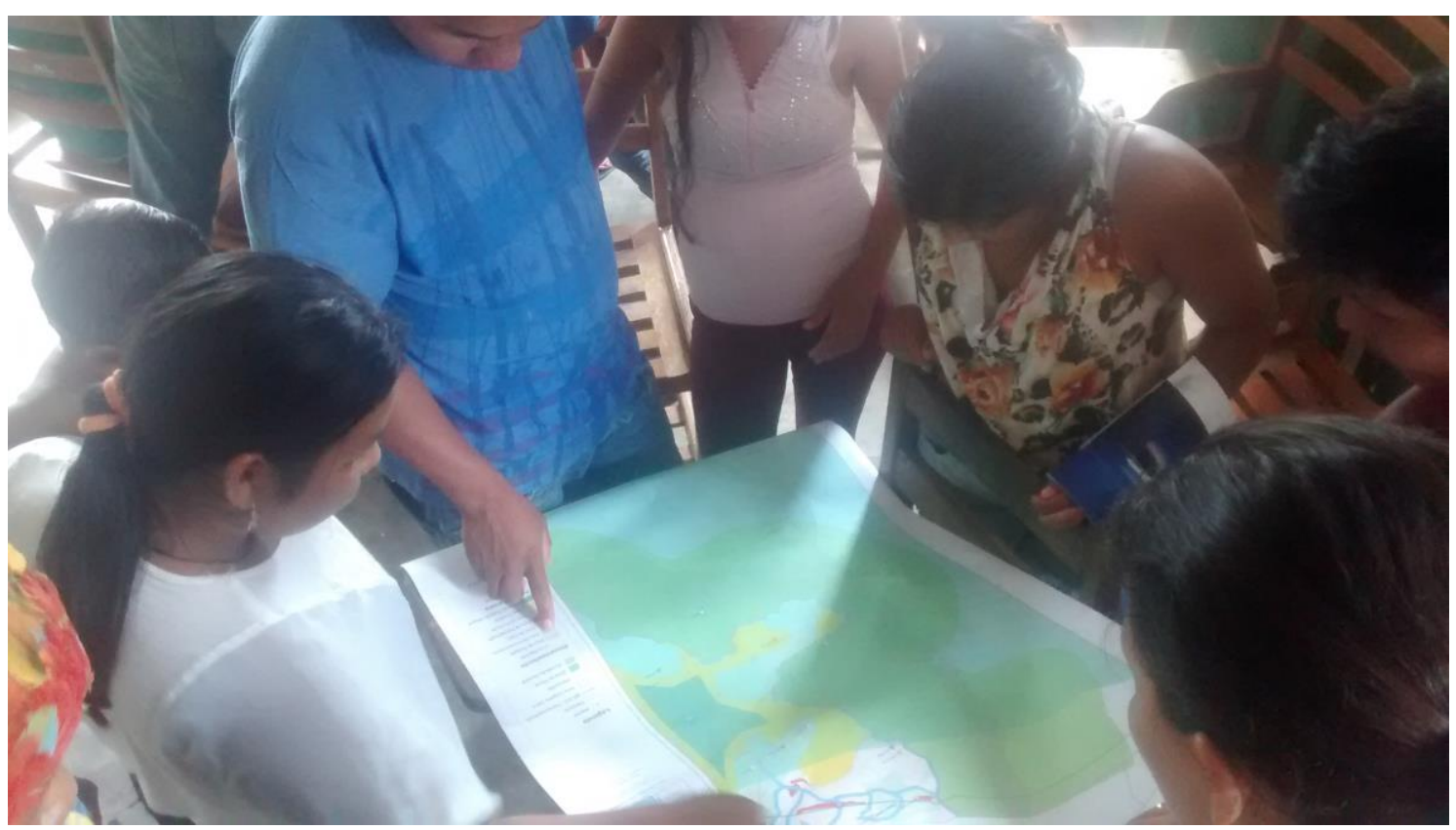

Figura 12 - Atividade de revisão do Etnozoneamento. TI Jiahui, aldeia Ju'i. Fonte: APIJ, 2014

É um trabalho que apresenta oito zonas diferenciadas pelo tipo de uso e aptidão da terra dentro dos limites de demarcação e também em seu entorno. Assim, ficaram definidas as seguintes zonas: Primitiva, Sagrada, Caça, Entorno, Produção, Proteção Integral, Recuperação e Resgate (fig 14). A comunidade definiu as atividades 
prioritárias para cada zona com o intuito de garantir a continuidade dos recursos e ao mesmo tempo a conservação. Revisitar o Etnozoneamento para fundamentar o planejamento do PGTA evidenciou a necessidade de atualização do trabalho. Algumas mudanças ocorreram no território.

Entre 2011 e 2014 a comunidade decidiu criar uma nova aldeia às margens da Transamazônica. A criação dessa aldeia pressupõe a ampliação da Zona de Produção, para viabilizar o cotidiano das famílias que ali se instalarão. Além disso, os indígenas identificaram um sítio histórico que ainda não havia sido mapeado. Essas foram as principais mudanças ocorridas no interior da TI que, evidentemente, devem constar no Etnozoneamento.

A Zona de Entorno é onde se tem conflitos mais evidentes em relação à sobreposição. Como mostra a Figura 13, é área que permeia todo o limite oeste da TI e está totalmente inserida na área da Flona. A comunidade identifica a região com a presença de lugares sagrados. É também uma área importante para pesca. As lideranças Jiahui defendem que o uso e ocupação dessa área devem ser exclusivos dos indígenas, ou seja, restritos aos moradores da Flona e demais agentes externos. Para levar adiante tal decisão é necessário investir na revisão do Acordo de Uso que possuem com o ICMBio e fortalecer a presença dos Jiahui no Conselho Consultivo da Flona.

O rio Maici coincide com os limites da TI, portanto, localiza-se nessa zona de maior conflito. Segundo o acordo de uso, a pesca nessa região só pode ser feita na margem esquerda, pois a direita já adentra ao território Jiahui. A proposta da comunidade é ter acesso exclusivo às duas margens do rio, garantindo a atividade da pesca, diretamente relacionada à subsistência. Nas aldeias acredita-se que a restrição de presença não indígena nessa região também contribuirá para a preservação dos lugares sagrados. 
Etnozoneamento da Terra Indígena Jiahui

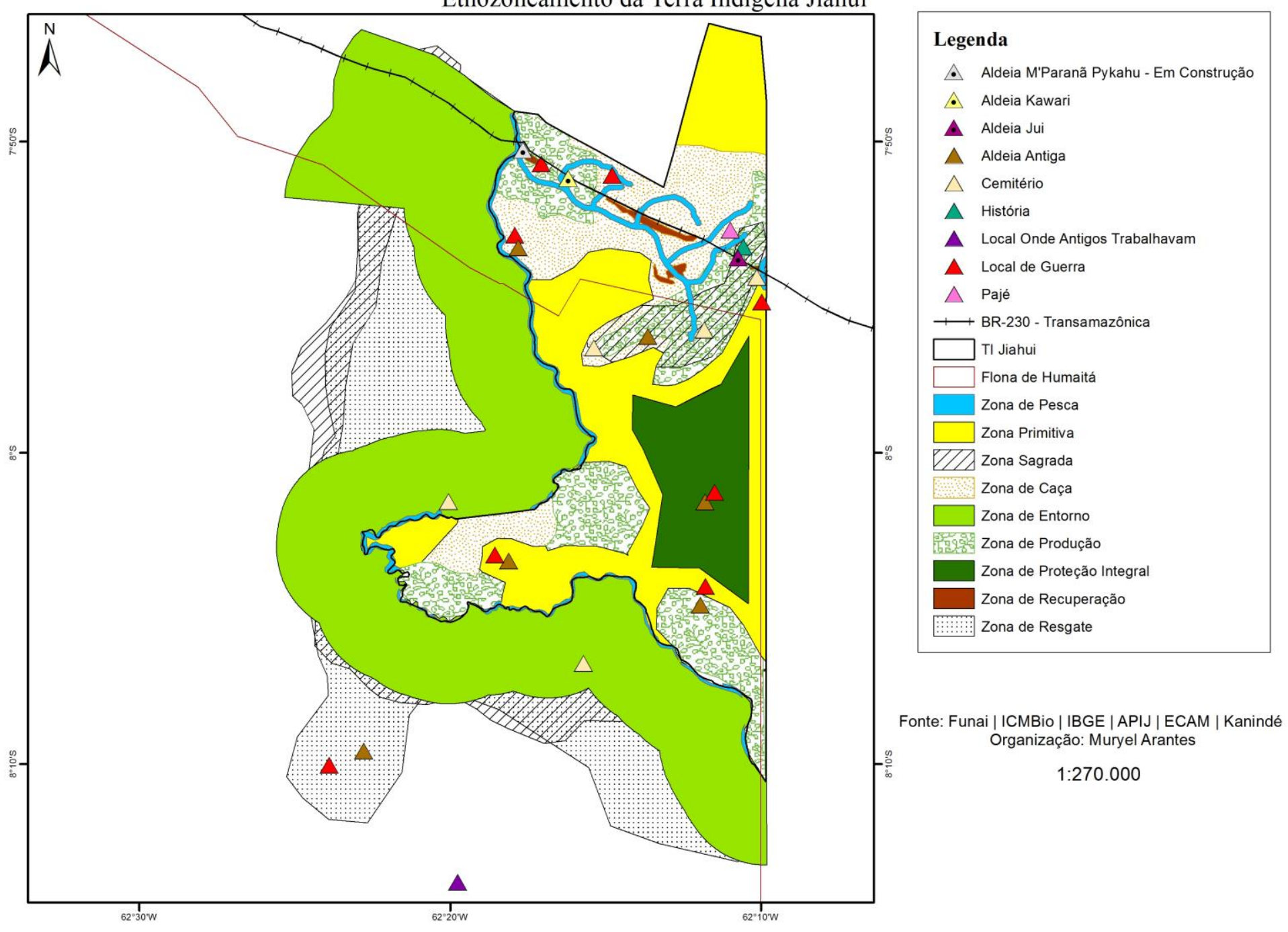

Figura 13 - Mapa do Etnozoneamento da TI Jiahui. 
Descrição das Zonas

\begin{tabular}{|c|c|c|}
\hline \multicolumn{3}{|c|}{ Descrição das Zonas } \\
\hline Zona & Características & Objetivo \\
\hline $\begin{array}{l}\text { Zona de Recuperação } \\
\text { (Thadivuradha } \\
\text { Nhadegura'pé) }\end{array}$ & $\begin{array}{l}\text { São áreas com desmatamento provocado } \\
\text { pelas ações de fazendeiros, garimpeiros, } \\
\text { grileiros, pescadores e caçadores, para a } \\
\text { retirada ilegal de recursos naturais }\end{array}$ & $\begin{array}{l}\text { Reflorestar para a manutenção } \\
\text { da biodiversidade e bem estar da } \\
\text { comunidade Jiahui }\end{array}$ \\
\hline $\begin{array}{l}\text { Zona de Proteção } \\
\text { Integral (Tape hoí } \\
\text { areguri’pé) }\end{array}$ & $\begin{array}{l}\text { É uma área que ainda não foi mexida, } \\
\text { que possui muitas riquezas naturais e que } \\
\text { se pretende proteger para o futuro, para } \\
\text { os filhos e netos a fim de que possam } \\
\text { usufruir e dar continuidade } \\
\text { na preservação }\end{array}$ & $\begin{array}{l}\text { Preservar a biodiversidade para } \\
\text { garantir o futuro do Povo Jiahui }\end{array}$ \\
\hline $\begin{array}{l}\text { Zona Sagrada (Te } \\
\text { Jhupawa) }\end{array}$ & $\begin{array}{l}\text { Compõe-se por algumas regiões dentro e } \\
\text { fora da TI Jiahui, principalmente a calha } \\
\text { do Rio Maici, onde há relatos de histórias } \\
\text { de guerras, rituais, festas, cemitérios, } \\
\text { mitos e aldeias antigas, que possuem } \\
\text { grande relevância para o fortalecimento } \\
\text { e manutenção da cultura, tradição e por } \\
\text { fim a identidade do povo indígena Jiahui }\end{array}$ & $\begin{array}{l}\text { Fortalecer o respeito pelos } \\
\text { sítios sagrados }\end{array}$ \\
\hline $\begin{array}{l}\text { Zona de Produção (Joro } \\
\text { Nhande Poronhuku`o) }\end{array}$ & $\begin{array}{l}\text { São áreas destinadas ao plantio e à coleta } \\
\text { de produtos florestais não madeireiros } \\
\text { (PFNM), para garantir a segurança } \\
\text { alimentar e geração de renda para o povo } \\
\text { Jiahui. A Zona de Produção contempla } \\
\text { produção diversificada e práticas } \\
\text { sustentáveis e responsáveis }\end{array}$ & $\begin{array}{l}\text { Promover a sustentabilidade e } \\
\text { gerar alternativas produtivas e } \\
\text { econômicas para o povo Jiahui. }\end{array}$ \\
\hline $\begin{array}{l}\text { Zona Primitiva (Hady Pey } \\
\text { Dypey Jhoro Kwaguri’pe) }\end{array}$ & $\begin{array}{l}\text { Área destinada à reprodução de espécies } \\
\text { florestais e animais para eventual } \\
\text { subsistência do povo Jiahui }\end{array}$ & $\begin{array}{l}\text { Manter o equilíbrio dos recursos } \\
\text { naturais da TI Jiahui }\end{array}$ \\
\hline Zona de Entorno & $\begin{array}{l}\text { Área destinada para frear os impactos de } \\
\text { atividades fora da } \mathrm{TI} \text {, mas que interferem } \\
\text { no território tradicional }\end{array}$ & $\begin{array}{l}\text { Minimizar os efeitos que um } \\
\text { futuro manejo dentro da Floresta } \\
\text { Nacional de Humaitá (FLONA } \\
\text { DE Humaitá) pode causar na } \\
\text { TI Jiahui (que possui cerca } \\
\text { de } 60 \% \text { do seu território em } \\
\text { sobreposição com a FLONA) }\end{array}$ \\
\hline Zona de Caça & $\begin{array}{l}\text { É a área destinada pela comunidade para } \\
\text { a atividade de caça }\end{array}$ & $\begin{array}{l}\text { Garantir a alimentação do Povo } \\
\text { Jiahui pelas atividades de caça } \\
\text { para subsistência }\end{array}$ \\
\hline Zona de Resgate & $\begin{array}{l}\text { Área de ocupação histórica do povo } \\
\text { Jiahui fora dos limites de demarcação }\end{array}$ & $\begin{array}{l}\text { Conservação e respeito aos } \\
\text { lugares sagrados e ao território } \\
\text { tradicional Jiahui }\end{array}$ \\
\hline
\end{tabular}

Tabela 10 - Informações sobre as zonas do Etnozoneamento 


\subsubsection{Mapa de Usos da Flona de Humaitá (Zoneamento)}

No contexto das UCs, o Zoneamento ${ }^{33}$ contido no Plano de Manejo (PM) é a principal ferramenta de gestão, já que define todo e qualquer tipo de intervenção feita nas UCs, especificando as possibilidades de uso. A elaboração dos PMs é realizada por equipes multidisciplinares que realizam um diagnóstico prévio da UC em questão, o que envolve estudos de meio físico, socioeconomia, histórico, etc., e em seguida apresentam o PM contendo zoneamento e planejamento para a UC (ICMBio).

A demanda pela elaboração do PM da Flona $^{34}$ foi inserida no contexto de outras 10 UCs da região, denominada Interflúvio Purus-Madeira ${ }^{35}$ (Figura 14). Essa região foi criada a partir de um grupo de trabalho instituído pelo MMA para acompanhar o Licenciamento Ambiental da BR-319. Neste contexto formou-se um subgrupo responsável pelas UCs da referida região, dentre as quais está a Flona de Humaitá. Com esse trabalho, somado a outras pesquisas desenvolvidas por entidades do terceiro setor, alguns estudos de diagnóstico - subsídios ao PM - já estão prontos e foram utilizados nesta pesquisa para suprir a ausência do zoneamento consolidado.

\footnotetext{
${ }^{33}$ Especificado no capítulo II, tópico 2.2.

${ }^{34}$ Conforme Lei do SNUC, os PMs devem ser elaborados no prazo máximo de cinco anos a partir da criação da UC. Apesar disso, o PM da Flona de Humaitá ainda encontra-se em fase de elaboração, 18 anos após a sua criação.

35 A área da "Região do Interflúvio Purus - Madeira" abrange cerca de $\mathbf{2 7 0 . 0 0 0 ~} \mathbf{K m}^{2}$, sendo aproximadamente 5,4 \% da área total da Amazônia Legal, que formam um grande mosaico funcional (mesmo que não instituído legalmente), formando corredores na quase totalidade da área (PNUD/MMA, 2013).
} 


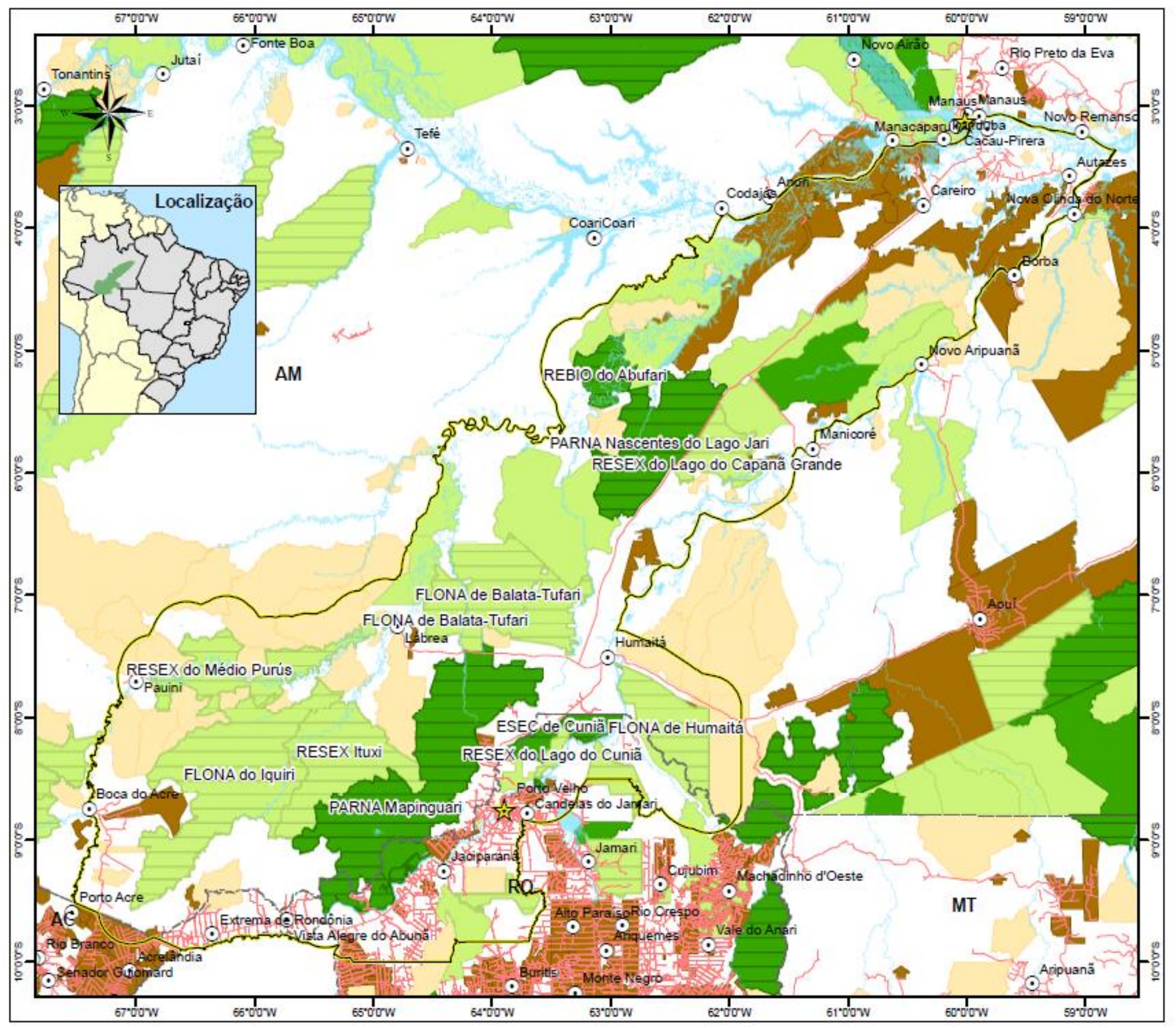

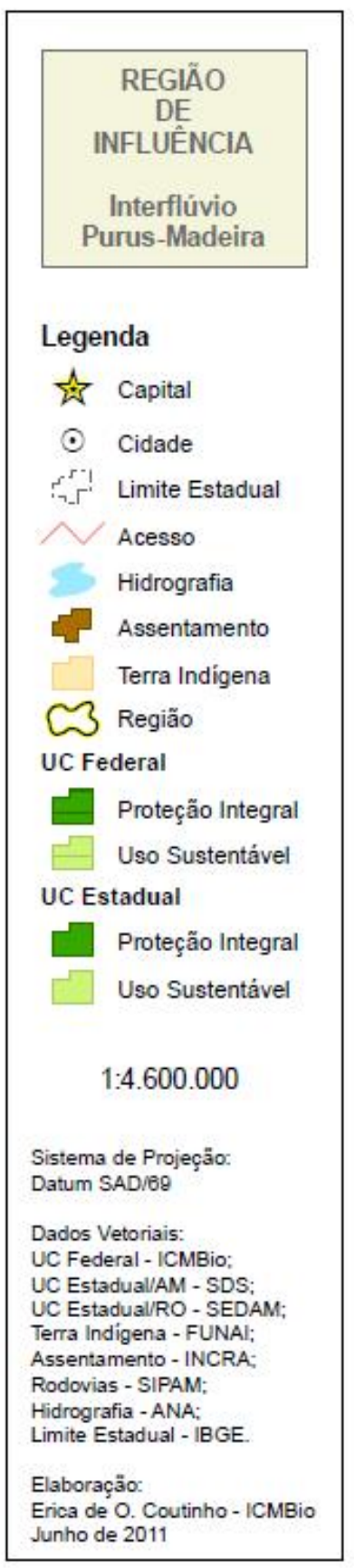

Figura 14 - Mapa de Localização da região do Interflúvio Purus-Madeira. Fonte: PNUD|MMA, 2013. 
O projeto Fonteiras Florestais realizado entre 2009 e 2013 produziu informações sobre os usos no interior da Flona. A partir disso identificou os tipos de áreas internas à UC. Com auxílio desse referencial, foi possível elaborar um mapa de uso da Flona.. Essa foi uma alternativa para representar o que seria, na metodologia aqui proposta, o Zoneamento. Segundo o estudo, o agrupamento de cada tipo de usou resultou na composição de zonas diferenciadas. Assim, os usos da Flona foram representados em três mapas: o primeiro com as diferentes áreas da UC (Figura15), o segundo e o terceiro com as definições dos tipos de uso que as caracterizam (Figura 16 e 17).

Na zona denominada Livre Concessão Florestal, as atividades de caça e pesca são predominantes, mas a área também é utilizada parcialmente para estoque de caça, agricultura de terra firme e extrativismo. A área de Uso Comunitário reúne todos as atividades produtivas e de subsistências dos moradores da flona: caça, pesca, agricultura, extrativismo e duas grandes áreas para o manejo comunitário florestal (Figura 15). A Zona de Intervenção Baixa foi identificada pela fronteira com a TI Jiahui. Os gestores e gestoras da Flona consideram que essa é uma área de acesso restrito em função da proximidade do território indígena.

No entanto, na Zona de Intervenção Baixa, que corresponde a mesma Zona de Entorno mapeada no Etnozoneamento dos Jiahui, foram identificadas atividades de caça e pesca dos moradores da Flona. Essas atividades, mesmo que previstas no Acordo de Gestão (publicado pelo ICMBio), não são de baixo impacto. A disponibilidade de peixes e qualidade da água são diretamente afetadas pela intensificação da pesca - o que ocorre pelo aumento no número de pessoas que a praticam na região: As interações com a fauna aquática e os recursos hídricos no entorno da TI influenciam ecossistemicamente a disponibilidade de recursos naturais no interior desse território. Esse fato se torna ameaçador considerando-se que a TI é menor em tamanho (hectares) e em população, se comparada à Flona. Por isso, é importante preservar os recursos fundamentais para a sobrevivência dos Jiahui restringindo as atividades dos moradores da Flona nas demais àreas da UC, preservando assim a Zona de Intervenção Baixa ou Zona de Entorno. 


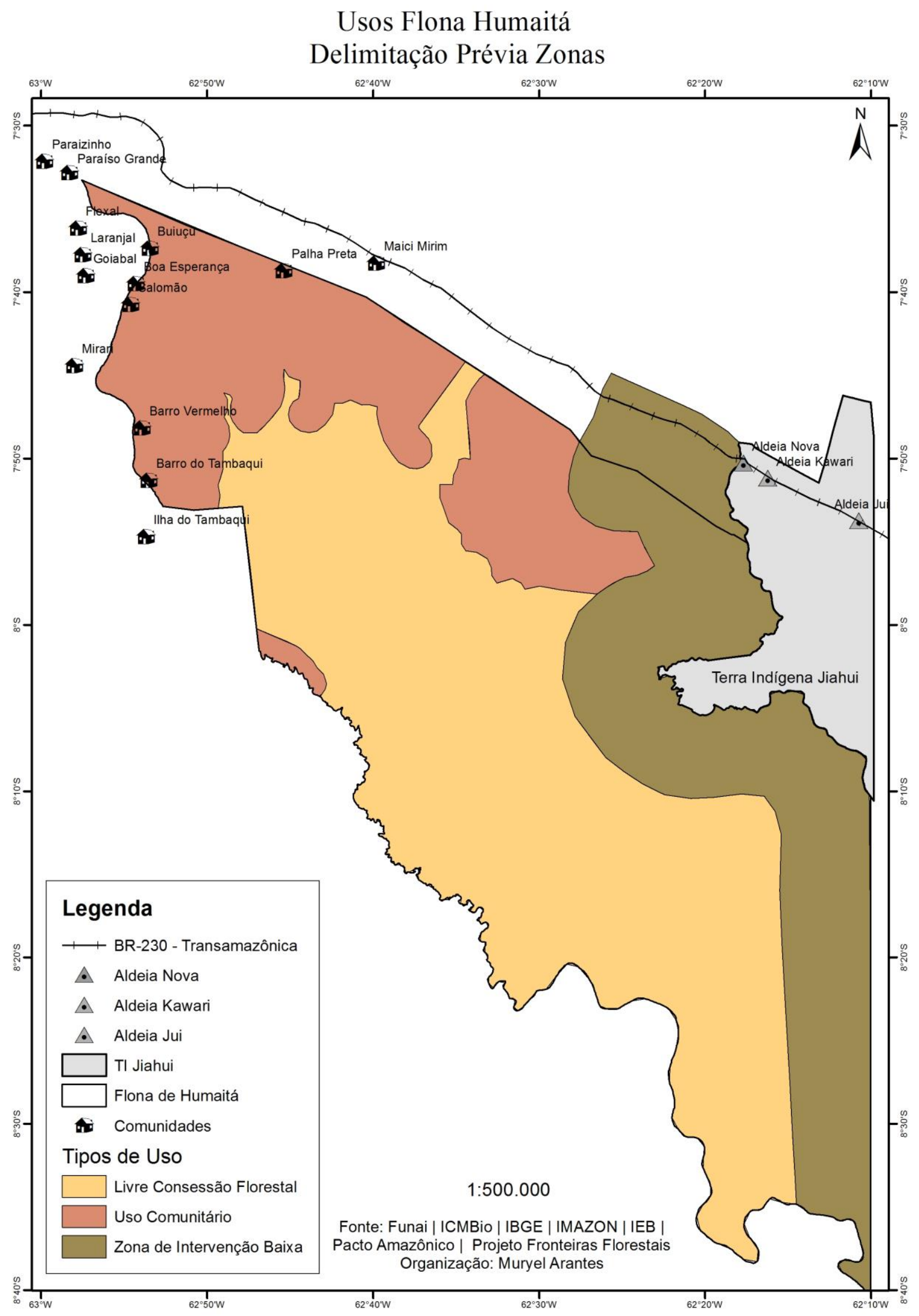

Figura 15 - Mapa Usos da Flona 


\section{Usos da Flona de Humaitá}

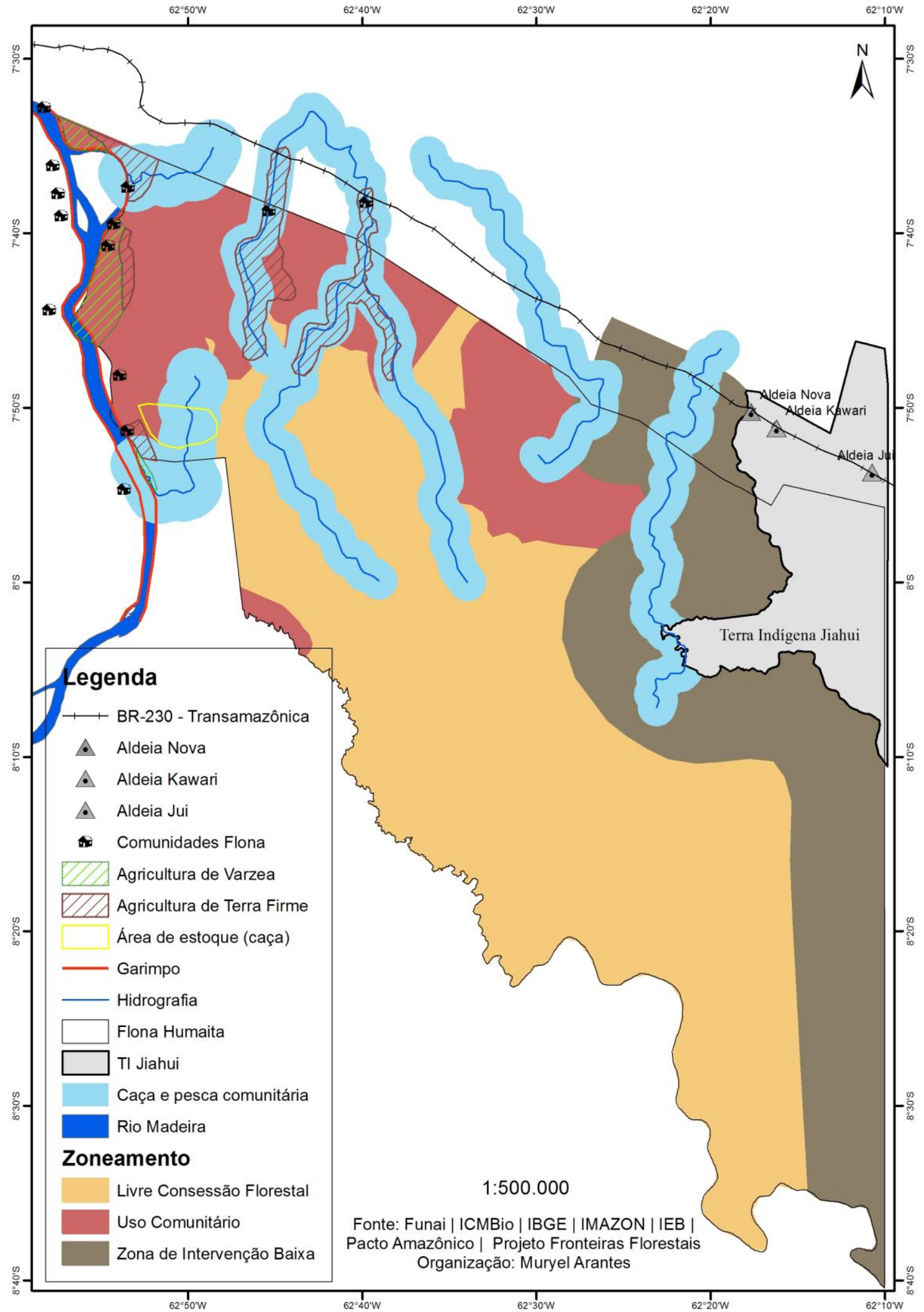

Figura 16 - Mapa Usos da Flona de Humaitá - atividades 


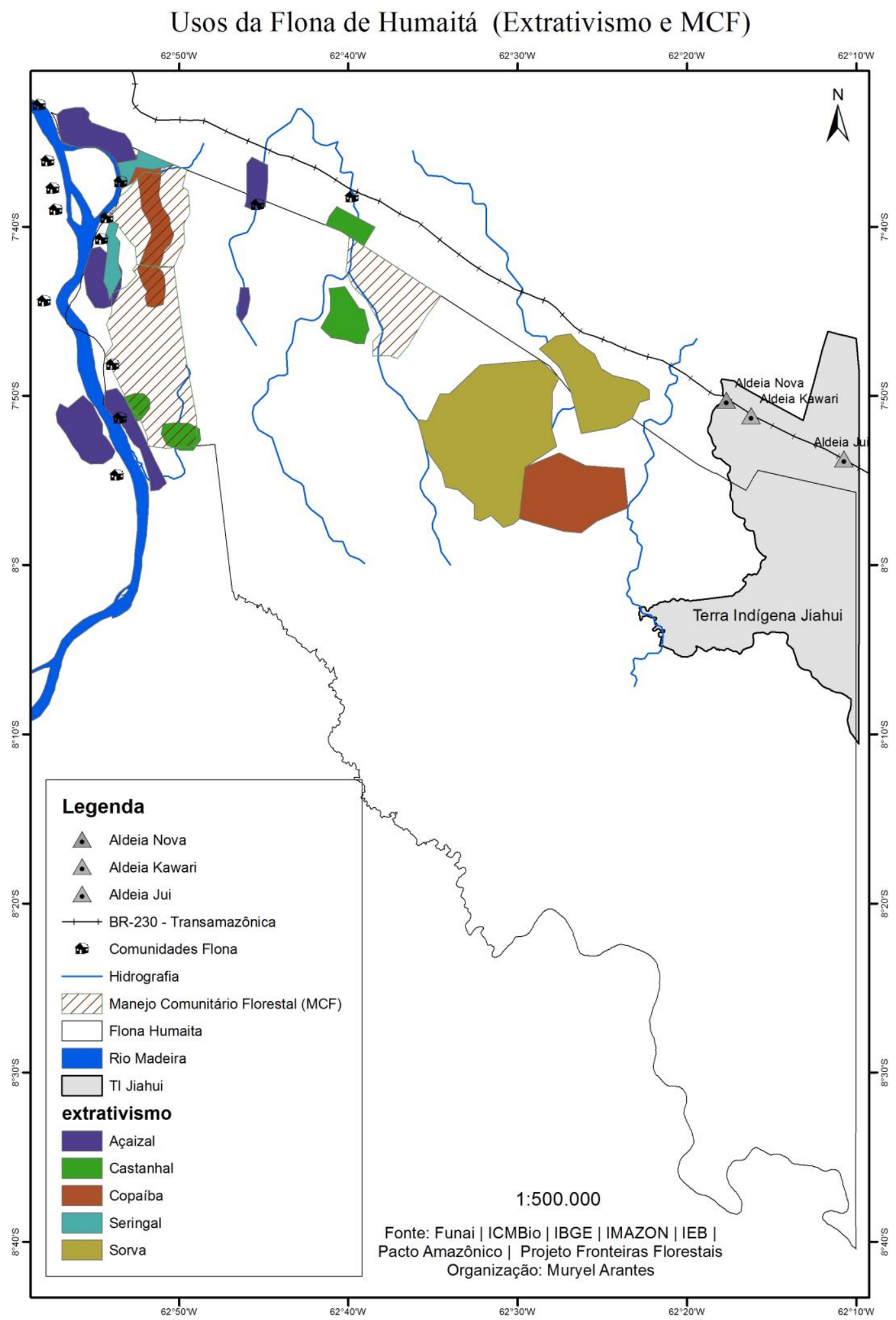

Figura 17 - Mapa Usos da Flona de Humaita - Extrativismo e MCF 


\subsubsection{Programa de Pesquisa em Biodiversidade (PPBIO)}

O PPBIO possui quatro Núcleos Regionais (NR) no estado do Amazonas localizados nos municípios de Tefé, São Gabriel da Cachoeira, Manaus e Humaitá. Criado em 2011, o NR Humaitá conta com parcerias de instituições públicas e do terceiro setor, tais como: Universidade Federal do Amazonas (UFAM), Instituto Internacional de Educação da Amazônia (IIEB), Instituto Pacto Amazônico (IPA), Instituto Brasileiro do Meio Ambiente e dos Recursos Naturais Renováveis (IBAMA), Instituto Nacional de Colonização e Reforma Agrária (INCRA), Instituto Chico Mendes de Conservação da Biodiversidade (ICMBio), Fundação Nacional do Índio (FUNAI), Secretaria Municipal do Meio Ambiente e Turismo (SEMATUR), Instituto de Desenvolvimento Agropecuário do Estado do Amazonas (IDAM).

Esse conjunto de parceiros, aliado à estrutura organizacional do PPBIO, compõe um representativo potencial de pesquisa, fiscalização, infraestrutura e envolvimento comunitário. Essas capacidades são primordiais para a gestão socioambiental e para a conservação de um modo geral. Apesar disso, o envolvimento do ICMBio na iniciativa de criação do NR Humaitá se mostrou pouco articulado. O instituto responsável pela gestão das UCs não definiu, por exemplo, um representante para acompanhar os trabalhos. A Funai, por outro lado, indicou um servidor e disponibilizou sua infraestrutura local (PPBIO, 2011).

A Flona de Humaitá não possui parceria com o PPBIO, mas segundo a chefa da UC, Leila Mattos ${ }^{36}$, existe conhecimento e intenção de participar do projeto, inclusive pela possibilidade de parceria com a UFAM. Nos projetos desenvolvidos pelo povo Jiahui e durante oficina - na qual se realizou a observação participante - não houve qualquer menção ao programa. Pela observação desse indicador constatou-se que os territórios protegidos ainda não utilizam a potencialidade do programa.

A transformação territorial observada neste indicador está relacionada à apropriação do território que ocorre durante o processo de produção e difusão de conhecimento científico. Na perspectiva da Flona, o uso para pesquisas, no contexto do PPBIO, não é significativo. Mas pode ser uma possibilidade a médio e longo prazo.

\footnotetext{
${ }^{36}$ Em entrevista concedida por e-mail em janeiro de 2016.
} 


\subsubsection{Projetos e iniciativas de Gestão Integrada e compartilhada}

As estratégias de gestão das UCs podem ser executadas de forma integrada, com outras UCs, e de forma compartilhada, entre Estado e OSCIPs. Na Flona de Humaitá não existe acordo de gestão com instituições do terceiro setor. O ICMBio é, portanto, a única instituição responsável pela gestão da UC. Diante desse fato, o foco de análise se direciona à gestão integrada. A possibilidade de realizar de forma integrada as ações de gestão das UCs próximas (ou que façam parte de um mesmo conjunto) reitera a importância dos mosaicos de áreas protegidas. Outro aspecto importante desse mecanismo pode ser observado no caso das sobreposições. Nessa situação a gestão integrada pode proporcionar a resolução de conflitos.

É importante ressaltar que o Art.26 do SNUC (cap. 2, 2.3.1) determina que nos casos de formação de mosaicos a gestão deve ser integrada e participativa. O intuito é assegurar que os objetivos de cada UC sejam cumpridos, respeitando suas diferenças. $\mathrm{Na}$ Amazônia, é recorrente que as TIs façam parte desses mosaicos. Por isso, nesse contexto de áreas protegidas diferenciadas, devem-se levar em consideração as TIs. Ao se observar a área de estudo por esta perspectiva constata-se que existem duas perspectivas de conjuntura: o mosaico funcional Purus-Madeira (Figura 14), formado por UCs, TIs e assentamentos no sul do Amazonas, e o Corredor Etnoambiental TupiKagawahiba (Figura 4), formado por TIs e UCs abrangendo o sul do estado e o norte de Rondônia.

Atualmente o PM da Flona de Humaitá está sendo desenvolvido juntamente com outras 11 UCs. Esse trabalho está sendo possível pelo fato da Flona estar inserida no mosaico funcional do Interflúvio Purus-Madeira. O GT BR-319, criado pelo MMA para encaminhar o licenciamento da rodovia, demandou a elaboração dos PMs das UCs da região. Trata-se de uma ação de Gestão Integrada que está contribuindo com a gestão da Flona. Na perspectiva da TI Jiahui as ações realizadas no âmbido do corredor etnoambiental resultaram na elaboração dos instrumentos de gestão da comunidade.

Em relação às sobreposições o SNUC prevê que os órgãos federais responsáveis pela política ambiental e indigenista (ICMBio e Funai) deverão instituir grupos de trabalho para regularização das eventuais superposições entre TIs e UCs. No caso dos territórios protegidos aqui abordados, não existe um GT formado para resolução da 
sobreposição em si. A ação que se tem nesse sentido restringe-se ao acordo de gestão publicado no Diário Oficial da União em julho de 2013.

A Gestão Integrada também faz parte das estratégias de gestão já mencionadas no primeiro indicador analisado. O diferencial, nesse caso, é que se trata da decisão das instituições estatais sobre a forma de gestão das UCs. No contexto do inteflúvio PurusMadeira, essa forma de gestão veio atender uma demanda de licenciamento ambiental e indiretamente contribuiu para o sentido conservacionista das UCs da região.

\subsection{PRESERVAÇÃO E CONSERVAÇÃO}

\subsubsection{Desmatamento}

Pelos índices de desmatamento é possível inferir que a cobertura vegetal dos territórios protegidos é conservada. Segundo dados do Prodes, até 2014 a Flona de Humaitá desmatou uma área de $5.2 \mathrm{~km}^{2}$, o que corresponde a menos de $1 \%$ de sua área total. No mesmo período, o desmatamento na TI Jihaui chegou a $18.9 \mathrm{~km}^{2}, 3,94 \%$ de sua área total. As imagens do mês de julho de 2015 obtidas pelo satélite Landsat8 (Figura 18) revelam que tanto no interior quanto no entorno dos territórios protegidos, a floresta encontra-se conservada. O que complementa a análise dos dados e reitera a afirmação inicial (INPE, 2014 e 2015).

O desmatamento nos territórios protegidos não apresenta proporções significativas de degradação. Apesar disso, é importante considerar a possibilidade de desmatamento seletivo, não detectável pelos satélites do Prodes. O sensoriamento remoto contribui significamente para o controle do desmatamento na Amazônia. No entanto, o corte seletivo de espécies exige, além de um refinamento manual (supervisionado) da classificação das imagens, a validação dos dados em campo.

Durante a elaboração do Etnozoneamento, realizado na TI Jiahui, foram mapeados alguns polígonos de desmatamento. Trata-se das zonas de recuperação, áreas que foram afetadas pelo desmatamento. Essas áreas localizam-se predominantemente às margens do trecho da Transamazônica dentro do território indígena (Figura 18). Apenas um polígono encontra-se mais distante da rodovia, na Zona de Caça e Pesca. Nenhum dos focos de desmatamento encontrados na TI encontra-se na área de sobreposição com a Flona. O mapa de usos da Flona não apresenta informação sobre a localização da ínfima taxa de desmatamento, nem qualquer área destinada à recuperação. 
No que tange à conservação da cobertura vegetal, a rodovia é o principal vetor de desmatamento nos territórios protegidos. $\mathrm{Na}$ área de sobreposição não há indícios de degradação que pressuponha esforços de restauração via reflorestamento. Assim, conclui-se que na área de sobreposição, a degradação por desmatamento não é um problema.

A transformação territorial evidenciada pela observação deste indicador está relacionada à adequação dos usos à conservação. Grandes polígonos de desmatamento, em geral, são causados por atividades inadequadas ao sentido conservacionista. Por isso, espera-se que os Territórios Protegidos tenham usos compatíveis com seus objetivos, consequentemente de baixo impacto na cobertura vegetal. Seguindo este raciocínio, pode-se inferir que o desmatamento constatado nos territórios indica que os usos não têm impacto significativo para a degradação da floresta. A partir desses dados infere-se que os usos já praticados pela comunidade são adequados ao sentido conservacionista dos territórios. Por outro lado, o uso da rodovia Trasamazônica provoca focos de desmatamento no interior da TI. 


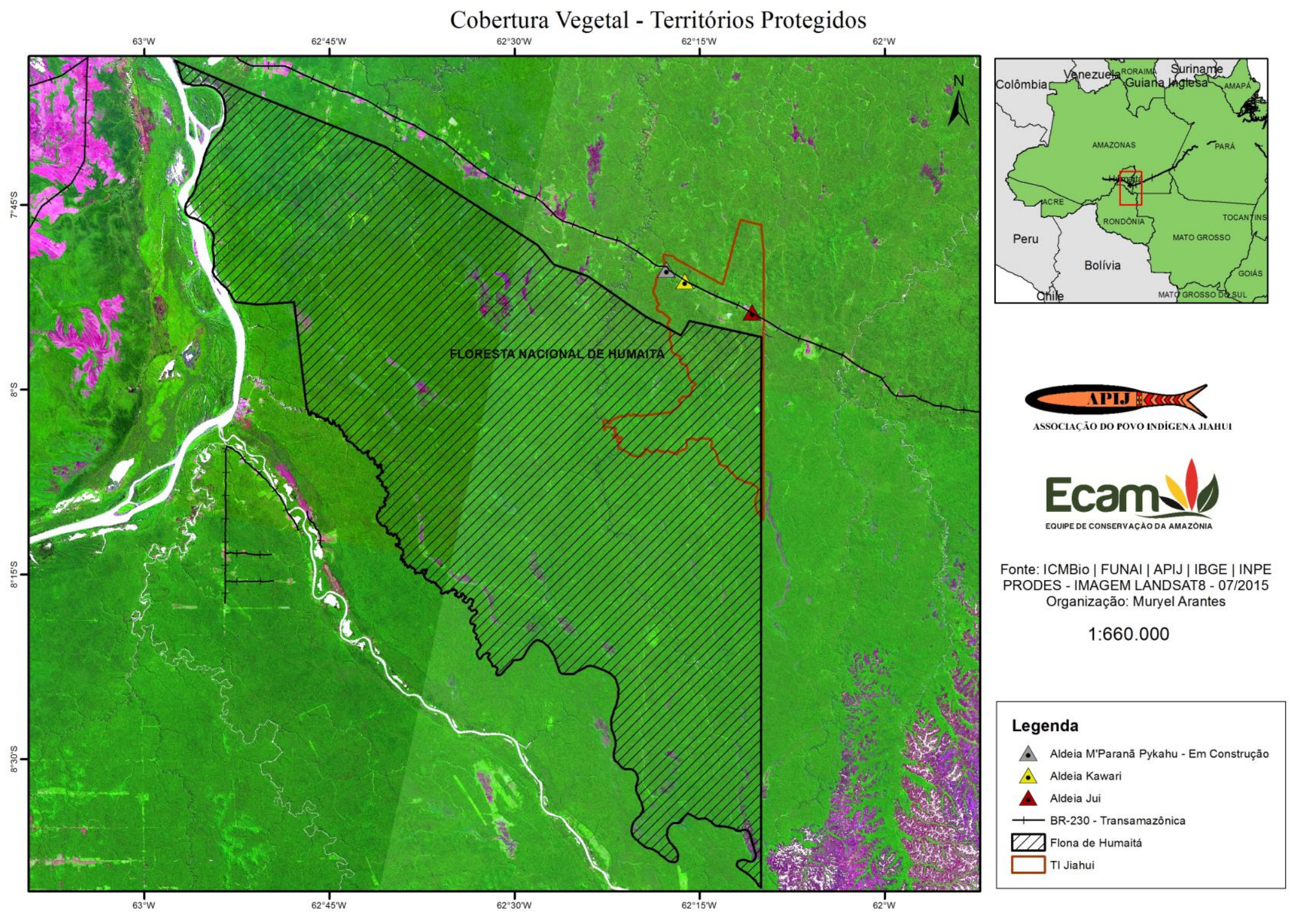

Figura 18 - Mapa com imagem da cobertura vegetal dos territórios protegidos 


\subsubsection{Acordos de Uso}

Os Acordos de Uso são fundamentais para os territórios protegidos em situação de sobreposição. O ideal nestes casos é a formação de um GT entre os órgãos responsáveis para regularização, conforme previsto na Lei do SNUC. Não é o que ocorre na TI Jiahui e Flona de Humaitá. Neste aspecto os territórios protegidos contam com um Acordo de Gestão (Portaria N 207, de 10 de julho de 2013, Diário Oficial da União de 17 de julho de 2013). Os usos registrados no acordo estão relacionados a atividades de extrativismo, uso de madeira, agricultura, criação de animais e pesca.

A atividade de pesca é a mais detalhada nos termos do acordo. Dentre as orientações contidas no documento destacam-se aquelas destinadas à comunidade Maici-Mirim e TI Jiahui. Para os comunitários da Flona é permitida a pesca no rio Maici-Mirim, apenas para subsistência. No rio Maici (Maici Grande) que faz divisa com a TI, está autorizada apenas a utilização dos igarapés de sua margem esquerda, pois a direita já adentra a TI. Para os indígenas é autorizada a pesca em todo o rio Maici e utilização dos peixes em festas tradicionais, ficando proibida apenas a venda.

Conforme demonstrado no Etnozoneamento (item 3.1.2) na Zona de Entorno - a mesma Zona de Intervenção Baixa da Flona - existe conflito de uso. Neste aspecto existem três perspectivas: 1) do ponto de vista da comunidade Jiahui é defendido que o uso nessa região seja restrito aos indígenas, 2) no Acordo de Gestão existe autorização para que os moradores da Flona pesquem na região, 3) pelo mapeamendo de usos, feito pelo projeto Fronteiras Florestais, trata-se de uma área de intervenção baixa (Figura 15) pela perspectiva da Flona, em função da proximidade com a TI.

Considerando a importância do entorno dos Territórios Protegidos, respaldado pelas diretrizes do SNUC e da PNGATI, somada a presença de lugares sagrados da população indígena, fica evidente a necessidade de revisão do Acordo de Gestão. A reivindicação por exclusividade da pesca na Zona de Baixa Intervenção (ou Zona do Entorno) deve ser considerada pela importância da soberania alimentar do povo Jiahui. A área em hectares da TI é menor em relação à Flona. Consequentemente o número de cursos d'água dentro de seus limites demarcados também é reduzido. Em contrapartida, 
a área de sobreposição é maior para o território indígena. $60 \%$ da TI é coberta pela sobreposição, já a área total da Flona é impactada em apenas $6 \%$ de sua área total.

\subsection{PREVENÇÃO E MITIGAÇÃO DE IMPACTOS NEGATIVOS}

\subsubsection{Incremento de desmatamento}

As taxas de incremento de desmatamento nos territórios protegidos são insignificantes. Como o desmatamento absoluto (3.2.1) é baixo, não foram consatados números representativos na análise do aumento desse processo. Na Flona de Humaitá o monitoramento do Prodes mostrou uma taxa anual de $0 \%$ para quase todo o período de 1997 a 2014. Excessão a isso foi o ano de 2001 que apresentou 0.01\%. Na TI Jiahui os mesmos índices foram encontrados para o mesmo período (INPE, 2015).

A observação desse indicador evidencia que as ações mais adequadas para a conservação da floresta, nos territórios protegidos, são as de prevenção. Exceto as áreas desmatadas às márgens da Transamazônica. Estas sim necessitam de um conjunto de ações preventivas, mitigadores e restauradoras, posto que já estão desmatadas e com tendência a degradação pelo impacto do tráfego na rodovia.

\subsubsection{Espécies-Chave}

$\mathrm{Na}$ Ecologia, o conceito de Espécies-Chave (Keystone Species) foi utilizado a partir dos anos 1960 para designar espécies de extraordinária importância na estrutura ecossistêmica. Paine (1969) demonstrou por meio de seu experimento com estrelas-domar, a importância dessa espécie para toda cadeia trófica. Sua retirada do meio causou impactos consideráveis, em especial a diminuição rápida do número de outras espécies locais. Incluindo neste conceito a perspectiva de inter-relação com populações humanas, ou seja, a interação humana com tais espécies, surgiu o conceito de Espécie-Chave Cultural (Cultural Keystone Species). Assim, o entendimento de que a presença ou ausência de determinadas espécies afeta drasticamente o ecossistemas passa a abarcar também grupos humanos (ASSIS, A.L. et. al.2010). 
No modo de vida indígena a caça é uma atividade de caráter cultural e de subsistência. Algumas espécies ocupam lugares centrais na cosmologia ${ }^{37}$ indígena e na alimentação nas aldeias. A dinâmica existente entre a fauna local e a vida dos Jiahui representa um importante aspecto de conservação socioambiental. Por esse motivo, as espécies cinegéticas encontradas na TI são Espécies-Chave Cultural. Para a gestão local, é importante realizar o monitoramento dessas espécies, visto que são vitais para a cultura e soberania alimentar da comunidade.

O projeto de Monitoramento da Biodiversidade está sendo desenvolvido na TI Jiahui com o objetivo de realizar tal acompanhamento. Sua metodologia consiste em registrar o peso e as espécies de animais abatidos durante a caça.

O resultado do biomonitoramento demonstrou que um total de 10 espécies diferentes são abatidas na TI Jiahui. Mas a observação deste indicador se restringe às duas principais - anta e queixada - aqui entendidas como duas das Espécies-Chave Cultural no território indígena. No período de 15 meses desse trabalho (2012-2013) foram registrados 4.402,5 $\mathrm{kg}$ de carne abatida nas aldeias Ju'i e Kawari. Desse total, as principais espécies abatidas foram: anta (Tapirus terrestris) com consumo de $600 \mathrm{~kg}$ na aldeia Kawari, e queixada (Tayassu pecari) com $644 \mathrm{~kg}$ consumidos na aldeia Ju'i.

Para compreender a presença dessas espécies no território indígena é relevante considerar também os apontamentos do Diagnóstico Etnoambiental Participativo (DEAP). Isso porque os estudos de fauna representam uma referência para entender a importância dos animais de caça.

Os resultados do DEAP mostraram alto número de indivíduos da espécie Tapirus terrestris no território Jiahui. Esse animal consta na lista vermelha da União Internacional para a Conservação da Natureza e dos Recursos Naturais (IUCN), na qual é classificado como vulnerável. Quando uma espécie entra nessa classificação significa que está correndo perigo de extinção. O fato de tal espécie ainda ser uma das mais consumidas nas aldeias (1000 kg no total), demostra o potencial da TI em ser refúgio da fauna ameaçada.

\footnotetext{
${ }^{37}$ São teorias do mundo. Da ordem do mundo, do movimento no mundo, no espaço e no tempo, no qual a humanidade é apenas um dos muitos personagens em cena. Cosmologias definem o lugar que os humanos ocupam no cenário total e expressam concepções que revelam a interdependência permanente e a reciprocidade constante nas trocas de energias e forças vitais, de conhecimentos, habilidades e capacidades que dão aos personagens a fonte de sua renovação, perpetuação e criatividade. Na vida cotidiana, essas concepções orientam, dão sentido, permitem interpretar acontecimentos e ponderar decisões. São expressas através da linguagem simbólica da dramaturgia dos rituais. Música, ornamentos corporais, entre outros recursos, permitem o contato com outras dimensões cósmicas, com momentos outros do mundo e do processo da vida e da morte (SILVA, A. L. ISA, 1995).
} 
A espécie Tayassu pecari, também é farta na TI Jiahui. A queixada é a carne preferida da comunidade. No período de monitoramento, os indígenas consumiram um total de $1064 \mathrm{~kg}$ nas duas aldeias. Pelos critérios da IUCN, trata-se de um animal em situação de quase ameaça. Essa classificação significa que a probabilidade de extinção é pouco preocupante, mas existe e pode ocorrer no futuro próximo. A disponibilidade dessa espécie para a caça é fator de extrema importância para a soberania alimentar dos Jiahui. A caça é a principal fonte de proteína dos (as) indígenas.

A observação da transformação territorial neste indicador foi direcionada a relação da comunidade com tais espécies, em seus costumes, e consequentemente ao estado de conservação que isso representa. Manter a tradição da caça em TIs faz com que as dimensões cultural e ambiental se interliguem, num processo de interdependência. Trata-se de uma atividade de apropriação do território que atribui sentido conservacionista à cultura indígena, à subsistência e ao ecossitema. Esta sequência pode ser considerada a síntese do deste sentido em territórios protegidos.

\subsubsection{Número de Espécies Ameaçadas de Extinção}

Os territórios protegidos guardam 10 espécies ameaçadas de extinção. De acordo com o monitoramento do ICMBio, na Flona de Humaitá existem duas: peixe-boi-daamazônia (Trichechus inunguis) e castanheira (Bertholletia excelsa). No DEAP da TI Jiahui, constam oito: macaco barrigudo (Lagothrix lagotricha), cuxiú (Chiropotes), coatá (Ateles belzebuth), anta (Tapirus terrestris), tatu canastra (Priodontes maximus), onça-pintada (Panthera onca), tamanduá bandeira (Myrmecophaga tridactyla) e queixada (Tayassu pecari). A ausência dessas espécies poderia impactar todo ecossistema da região, incluindo o modo de vida das populações que habitam os territórios protegidos.

Na Flona e na TI Jiahui, as atividades de caça e extrativismo envolvem algumas dessas espécies. A castanha, por exemplo, é um dos principais produtos comercializados na micro-região do Madeira. Parte dessa produção vem dos castanhais existentes nos territórios protegidos. É uma espécie significativa para subsistência e geração de renda de indígenas e comunitários da Flona. Os impactos negativos causados pelo desaparecimento de uma espécie como essa afetaria de maneira cíclica a dinâmica socioambiental local. Pois quanto menos diversificado o extrativismo, maior a pressão 
sobre outras espécies, mais difícil realizar o manejo sustentável, o que poderia causar o desaparecimento de outras espécies, inclusive animais.

Como antes mencionado, dois animais de caça estão na lista da IUCN, a anta e a queixada. $\mathrm{O}$ fato de serem espécies vulneráveis e ao mesmo tempo muito importantes para dieta proteica da comunidade, reafirma a importância do manejo sustentável. O biomonitoramento realizado na TI é uma das ferramentas para esta demanda. Não consta informação sobre atividades de pesca do peixe-boi-da-amazônia nos estudos diagnósticos dos Territórios Protegidos.

Uma das metas nacionais para a conservação da biodiversidade, segundo o MMA, é ter $100 \%$ das espécies da fauna ameaçada em Unidades de Conservação. Para esta medida protecionista ser efetiva é importante considerar a representatividade territorial de TIs e UCs de uso sustentável. Sobretudo os aspectos de manejo comunitário.

\subsection{DIMENSÃO SOCIOCULTURAL}

\subsubsection{Agentes Ambientais Indígenas (AAI) Mulheres}

Na TI Jiahui existem seis AAIs capacitados, são quatro homens e duas mulheres. A representatividade das mulheres nesse tipo de estratégia de proteção territorial ainda é baixa. É importante refletir sobre a participação das indígenas nessas formações.

O aprendizado desenvolvido durante a formação dos AAIs é amplo, pois envolve atividades de educação ambiental, articulação política, expedições de vigilância, técnicas de sobrevivência, primeiros socorros, dentre outros. Tais exercícios fortalecem a governança do território e a qualidade de vida nas aldeias. É fundamental que as mulheres possam, juntamente com os homens, participar ativamente de tais exercícios.

As duas AAIs mulheres da TI Jiahui representam o potencial da participação feminina, contribuindo com as estratégias de proteção territorial. Ainda que sejam minoria, essas duas AAIs contribuem para o fortalecimento do papel das mulheres na conservação do território indígena, conforme especificado na PNGATI.

O papel das mulheres nos territórios indígenas se diferencia dependendo da etnia, da comunidade, do histórico, dentre outros fatores. Mas em todo caso é importante avaliar como as mulheres se inserem no cotidiano de suas comunidades. Para os Jiahui, a formação de AAI contribui para a proteção territorial e educação ambiental. A participação das indígenas nessa demanda mostra uma transformação territorial relacionada à ampla participação da população nas atividades cotidianas da 
comunidade, mesmo que a participação das mulheres Jiahui nessas formações ainda seja pequena.

\subsubsection{Projetos e atividades dos moradores da FLONA}

As comunidades que habitam a Flona estão localizadas dentro dos limites da UC, ao norte e noroeste, e também no entorno, na zona de amortecimento (Figura 15). Cerca de 400 famílias vivem na região e desenvolvem atividades de caça, pesca, extrativismo e agricultura. A maioria é composta por pequenos produtores familiares, que concomitantemente são pescadores, extrativistas e garimpeiros de ouro fluvial. Parte da renda desses comunitários é complementada por programas sociais como Bolsa Verde, por exemplo.

Essas populações estão representadas pelas seguintes organizações: Assossiação dos Moradores do Maici-Mirim (AMARIM), Associação dos Moradores das Barreiras do Tambaqui (AMBATAM), Associação dos Moradores de Barro Vermelho (AMORBARV), Associação dos Moradores do Paraná do Buiuçú (AMPAB) e Associação dos Produtores de Calama e Maici (APROCAM). Todas fazem parte do conselho consultivo da Flona para o qual levam pautas sobre a necessidade de apoio à agricultura familiar, manejo de madeira e extrativismo.

Segundo a gestão da Flona não existem, por parte do ICMBio, projetos de apoio à produção em andamento. Neste caso, os programas de fomento a agricultura familiar se tornam as principais oportunidades de apoio à produção local. As comunidades de Buiçu e Salomão estão envolvidas no projeto de incentivo aos produtos da agricultura familiar da Companhia Nacional de Abastecimento (CONAB). Mas a participação dos moradores da Flona neste tipo de projeto ainda é insipiente. Os representantes das associações relatam que um dos entraves à participação nestes programas é a dificuldade de ter comprovações como o Documento de Origem Florestal (DOF) e a Declaração de Aptidão ao Pronaf ${ }^{38}$ (DAP).

Para que o PM possa contribuir para as certificações de produção local, é imprescindível que o manejo florestal comunitário seja inserido no zoneamento da Flona. Enquanto o PM não é publicado, as associações devem elaborar seus projetos produtivos com previsão orçamentária e de produção para fundamentar suas

\footnotetext{
${ }^{38}$ Programa Nacional de Fortalecimento da Agricultura Familiar
} 
reivindicações. Neste aspecto é possível observar que existe uma demanda para capacitações dos associados em elaboração de projetos e sistematização de informação.

A transformação territorial evidenciada neste indicador se relaciona as condições de vida na Flona. A sustentabilidade nesse tipo de UC depende da capacidade de subsistência e geração de renda dos moradores. A análise deste indicador mostrou que o uso para atividades produtivas está sendo realizado mas não existem projetos específicos de apoio aos produtores e extrativistas da Flona.

\subsubsection{Programas do Plano de Gestão Territorial e Ambiental (PGTA) da TI Jiahui ${ }^{39}$}

O PGTA do povo Jiahui foi elaborado durante oficina de 2 dias, que ocorreu em dezembro de 2014 na aldeia Ju'i. A metodologia para construção do documento foi colaborativa entre indígenas e equipe técnica. Os trabalhos foram realizados em quatro etapas: na primeira foi realizado um diálogo sobre a fundamentação legal e de políticas públicas para elaboração do PGTA e também a revisão do Etnozoneamento; na segunda foram listadas as necessidades da comunidade; na terceira foram definidas as prioridades e na quarta foi realizado o planejamento estratégico para cada área. $\mathrm{O}$ resultado deste trabalho são quatro programas que representam as prioridades de gestão para a comunidade Jiahui.

Comunicação, Proteção Territorial, Alternativas Econômicas/Produção, Fortalecimento Institucional e Educação/Saúde foram os programas definidos no planejamento do PGTA. Em cada um constam os objetivos, as atividades, as instituições parceiras e indicadores para o monitoramento. Os indígenas entendem que para a gestão do território é importante desenvolver ações específicas nessas áreas. Tanto os temas priorizados quanto o fato dos indígenas realizarem esse planejamento contemplam as diretrizes da PNGATI relacionadas ao fortalecimento político interno e externo, autonomia sociocultural, governança e participação indígena.

O programa Comunicação surgiu com o objetivo de melhorar o diálogo entre os atores dentro e fora da TI. A partir da realização de ações para alcançar o objetivo

\footnotetext{
${ }^{39}$ O PGTA Jiahui também é considerado um indicador referência, pois tanto sua elaboração quanto seu conteúdo são subsídios para a reflexão sobre a gestão dos territórios protegidos. Considerando a metodologia proposta, este seria um dos indicadores referência (conforme item 3.1), mas por se tratar de dados primários, obtidos por meio de observação participante, e também por mostrar o planejamento comunitário, foi considerado pertinente observa-lo no contexto da dimensão sociocultural.
} 
principal, a comunidade prevê alcançar outras conquistas, tais como: divulgar as ações do povo Jiahui; melhorar o ensino nas escolas; agilizar as denúncias de invasão na TI; melhorar a comunicação com parceiros e outros povos indígenas e desenvolver um sistema de inclusão digital. As atividades necessárias para o desenvolvimento deste programa dependem basicamente de instrumentos de comunicação como internet, telefone e radiofonia. É importante também promover capacitações para o uso de equipamentos de comunicação. A APIJ foi designada como princial responsável pelo desenvolvimento deste programa, incluindo o acompanhamento de seus indicadores, que são medidos pela quantidade de pessoas capacitadas.

O programa denominado Proteção Territorial tem o objetivo de proteger a TI e monitorar os recursos naturais. Para tanto é necessário melhorar o diálogo com o ICMBio e a Funai, monitorar a caça e a pesca e realizar a vigilância nos limites do território. Para isso, a comunidade prevê reuniões com as instituições governamentais, realizar o biomonitoramento todo ano, elaborar o cronograma das expedições de vigilância e a cada 5 anos formar cinco AAIs e agentes de biomonitoramento. Com este trabalho, a expectativa é conseguir que o Acordo de Gestão seja revisado anualmente, que as futuras gerações tenham acesso aos recursos naturais e que o território esteja protegido dos agentes externos de degradação.

O programa Alternativas Econômicas/Produção tem como foco principal a sustentabilidade no território indígena. Este programa é centrado na geração de renda a partir de boas práticas coletivas. A comunidade espera ter melhores caminhos ${ }^{40}$ para $\mathrm{o}$ extrativismo, conhecer mais as plantas medicinais, mecanizar o trabalho nas roças, implantar um Sistema Agroflorestal (SAF) e cultivar a prática de artesanato entre homens e mulheres. As ações previstas são: fazer a limpeza dos caminhos, adquirir equipamentos para beneficiamento dos produtos do extrativismo, promover o aprendizado sobre as plantas medicinais, implementar o SAF na zona de recuperação e construir um espaço para a prática e o ensino do artesanato.

O programa Fortalecimento Institucional foi criado para apoiar as atividades da APIJ. A associação precisa de subsídio para desenvolver suas atividades administrativas, promover parcerias com outras instituições e capacitar novas lideranças. As atividades previstas para este programa são: construção de sede da Apij

\footnotetext{
${ }^{40}$ Aqui o sentido de caminho se refere tanto às alternativas quanto aos caminhos, propriamente ditos, utilizados para chegar até os castanhais, açaizais, etc.
} 
na aldeia; adquisição de equipamentos de escritório e carro; busca por novas parcerias e capacitações para a diretoria e lideranças. Com a APIJ fortalecida e atuante, a comunidade pretende buscar apoio financeiro para seus projetos.

As questões de saúde e educação foram abordadadas no mesmo programa. O objetivo deste planejamento foi conquistar melhores condições de saúde e educação fortalecendo o papel da comunidade nessa busca. As ações previstas para atingir este objetivo foram: mobilizar os conselheiros para que eles cobrem melhor atendimento da Secretaria Especial de Saúde Indígena (SESAI); promover capacitações para Agentes Indígenas de Saúde (AIS) e microscopista; construir um posto de saúde em cada aldeia; construir poços artesianos e lavanderias e buscar capacitações para os conselheiros de saúde. Para a educação as metas foram construção de escolas nas aldeias, formação de professores indígenas e diretrizes para os indígenas nas polítias educacionais.

As instituições indicadas para auxiliar no desenvolvimento das ações de cada programa foram instituições do terceiro setor, órgãos públicos das esferas municipal, estadual e federal, a própria comunidade e a APIJ. É preciso buscar constantemente a aproximação com estas instituições para firmar parcerias que possam auxiliar na implementação das ações previstas. O PGTA Jiahui foi pensado para 40 anos, mas para se atingir o cenário ideal em 2054 é preciso que a comunidade acompanhe cada programa e que as instituições responsáveis também cumpram seu papel.

A transformação territorial evidenciada pelos programas do PGTA Jiahui é a diversidade de usos que a comunidade realiza em seu processo de apropriação do território. Os cinco grandes temas priorizados no planejamento dos indígenas mostram que a gestão pensada em escala local está em sintonia com as diretrizes da política nacional. Direcionam ainda possíveis ações para o desenvolvimento dessas áreas na TI. Essa perspectiva comunitária contribui para a manutenção da conservação socioambiental no território. 


\subsection{PRÁTICAS EDUCATIVAS}

\subsubsection{Capacitações}

A demanda por capacitações aparece várias vezes no planejamento do PGTA. O costume de recorrer a estes cursos surge durante o desenvolvimento de projetos e estudos realizados pela comunidade Jiahui e seus parceiros. Por isso tornou-se comum pensar nas capacitações para dinamizar o processo de troca de saberes. Nessas atividades, que geralmente envolvem indígenas e não indígenas, são promovidos o uso de novas tecnologias, a reflexão conjunta sobre o território, debates sobre políticas públicas, aprendizado sobre sistemas produtivos, etc. Desse modo as capacitações mostram os tipos de uso priorizados na escala local, o trabalho realizado e as tendências para outros usos, outras atividades. Em síntese, as capacitações mostram o que os atores locais estão fazendo e o que planejam fazer.

$\mathrm{Na}$ TI Jiahui ocorreram capacitações destinadas à formação de Agentes Ambientais Indígenas (AAI), Agentes Indígenas de Saúde (AIS) e Agentes Indígenas de Saneamento (AISAN). Essas formações contemplam questões ambientais e de saúde e evidenciam que estas foram as prioridades da comunidade indígena. Para o futuro os Jiahui prevêm mais capacitações nessas áreas e também inovações, tais como: uso de equipamentos de comunicação, boas práticas produtivas (açaí e copaíba), uso de plantas medicinais, artesanato e técnicas administrativas para a APIJ.

Em 2011 o ICMBio promoveu uma capacitação para o Conselho Consultivo da Flona na comunidade Maici. A pauta foi sobre o Programa de Aquisição de Alimentos da Agricultura Familiar (PAA) da Companhia Nacional de Abastecimento (CONAB); o Plano de Manejo Florestal Sustentável comunitário (PMFS), com ênfase nos procedimentos administrativos para exploração de recursos madeireiros no interior de UCs de Uso Sustentável. Houve também um diálogo sobre o andamento do PM das UCs do interflúvio Purus-Madeira (ICMBIO, 2011). No mesmo ano os conselheiros da Flona também participaram do Encontro dos Conselheiros Extrativistas do Sul do Amazonas. Em 2012, o Instituto Pacto Amazônico (IPA) promoveu uma capacitação em meliponicultura na comunidade Barreira do Tambaqui.

Na perspectiva da Flona, a demanda por novas capacitações são voltadas para as associações. Essas instituições necessitam se organizar para garantir a legalidade dos sistemas produtivos locais e o acesso às políticas públicas. Segundo a gestão da Flona as 
ações de capacitação ocorrem em iniciativas isoladas, ou seja, não existe um projeto específico para esta abordagem na UC.

A transformação territorial evidenciada por este indicador está relacionada às prioridades dos atores locais. Na TI, tanto as capacitações já realizadas quanto as previstas para o futuro revelam a intenção de trabalhar conhecimentos na área de Saúde e Ambiente. Mostram também a necessidade de fortalecer o aprendizado sobre produção e proteção do território.

Na Flona, as capacitações mostram que as comunidades têm se organizado para formações nas áreas produtivas e de governança, mas ainda precisam alcançar as formações demandadas para fortalecer as associações.

\subsubsection{Atividades de Educação Ambiental}

O exercício de pensar os aspectos de gestão dos territórios como proteção, alternativas produtivas, biomonitoramento, etc. já insere os atores locais numa reflexão compatível com os preceitos da Educação Ambiental. Pelo fato de ser transversal às atividades já desenvolvidas pelas populações locais, a Educação Ambiental é experimentada cotidianamente. A pauta socioambiental está presente nas atividades comunitárias, como não poderia deixar de ser, posto que são territórios destinados à conservação.

O que ainda não existe é uma iniciativa específica para o desenvolvimento do tema, tanto na UC quanto na TI. Considerando a problemática socioambiental que se vive hoje, é importante promover espaços de reflexão sobre ameaças à conservação que pressionam os territórios protegidos, tais como: mudanças climáticas; poluição; perda da biodiversidade; etc. A gestão da Flona afirma que é necessário investir fortemente nesse tema em toda a região do sul do Amazonas, visto que é uma região do franco avanço do desflorestamento e adensamento demográfico.

A transformação territorial oriunda das atividades de Educação Ambiental ocorre pelo enfoque específico dado a dimensão socioambiental para construção de cenários futuros sustentáveis. Os usos com essa finalidade ocorrem nos territórios protegidos, mas não são nomeados dessa forma. A análise desse indicador revela a necessidade de aprofundamento na reflexão sobre a Educação Ambiental inerente ao modo de vida indígena e comunitário e aquela elaborada e nomeada como tal nos moldes do sistema educacional brasileiro. 


\subsection{TRANSFORMAÇÕES TERRITORIAIS, POLÍTICAS DE GESTÃO E CENÁRIOS FUTUROS}

As sobreposições entre Territórios Protegidos são reflexos da ação estatal que, atualmente, realiza-se por meio de políticas públicas setoriais. Na configuração de tal cenário - de sobreposições - a criação e gestão das UCs tem sido protagonista. Isso porque uma vez que o processo de territorialização das TIs é anterior ao das UCs, as sobreposições se efetivam com a criação das UCs. Dessa maneira, torna-se evidente uma problemática no âmbito da gestão estatal responsável pela criação e manutenção dessas áreas.

Se o agir do Estado ocorre por meio das políticas públicas, é a PNMA e a Constituição Brasileira que indicam, no âmbito das questões ambiental e indígena, o principal meio para tal exercício. Este caminho é a criação de espaços territoriais especialmente protegidos e o reconhecimento das terras tradicionalmente ocupadas, ou seja, os Territórios Protegidos. Nesse contexto, SNUC e PNGATI foram as políticas criadas para estabelecer as normativas de criação, reconhecimento e gestão de tais territórios. No entanto, tais políticas foram elaboradas em setores diferentes. O que nos leva à conclusão de que se criou uma estratégia setorial para lidar com questões eminentemente espaciais e fundamentadas na importância dos territórios.

As diretrizes dessas políticas são complementares e reforçam a conservação nos territórios. Mas os usos, que de fato atribuem sentido conservacionista às UCs sustentáveis e TIs, estão sujeitos a mecanismos de gestão setoriais distintos, que implementam normas e instrumentos falhos no que diz respeito à complementariedade $\mathrm{e}$ integração. Para que as ferramentas de gestão funcionem em sintonia com as diretrizes é necessário investir em mecanismos de integração, em detrimento daqueles de sobreposição.

As metodologias do Etnozoneamento e do Zoneamento resultam de políticas com históricos distintos. Enquanto o primeiro se consolidou como ferramenta de planejamento que fortalece a autonomia indígena sobre o território, o segundo faz parte do conjunto de ferramentas de comando e controle estatal. Ambas as ferramentas são importantes no atual contexto de pressões e degradações. Mas se elaboradas e 
implementadas de forma conjunta, com técnicas integradas, representariam melhor a dinâmica territorial local e as próprias diretrizes do SNUC e da PNGATI.

Apesar do Etnozoneamento Jiahui ter sido feito em grande parte na área de sobreposição com a Flona, posto que a TI está sobreposta em 60\% de sua área total, observou-se autonomia dos indígenas para elaboração de tal ferramenta. O mapa de usos da Flona revelou maior intensidade de uso nas áreas da UC mais distantes da TI. Ainda assim, na zona de entorno, localizada na região do rio Maici, encontram-se conflitos de uso (Figura19).

O mapa de uso da Flona (Figura15,16 e 17) revelou que a Zona de Entorno é considerada como de "baixa intervenção" em função da proximidade da TI. Mas, na representação espacial das atividades de caça e pesca observou-se que tal zona é mapeada para tais atividades pelos moradores da Flona. As informações do Acordo de Gestão confirmam tal observação, pois prevê que:

No rio Maici, chamado também de rio Maici Grande, a comunidade utiliza os igarapés da margem esquerda, sendo estes o Igarapé da Praia, da Colher e Laguinho. Os moradores do Maici-Mirim não ficam autorizados a adentrar na Terra Indígena Jiahui (ICMBIO, 2013).

Desse modo, os comunitários da Flona ficam autorizados, mesmo que restritos à margem esquerda, a realizar suas atividades de caça e pesca na região. Este é um ponto de conflito, pois o Etnozoneamento dos Jiahui representa zonas de uso indígena nessa mesma região. Dessa maneira, boa parte da Zona de Baixa Intervenção (perspectiva do mapa de usos da Flona) e Zona de Entorno (perspectiva do Etnozoneamento) foram mapeadas pelos indígenas como zonas sagradas e de resgate, pois guardam sítios sagrados, como local de guerra e aldeia antiga (Figura 19). Com base nisso, a comunidade Jiahui defende que o uso dessa área deve ser exclusiva dos indígenas. 
Usos na Zona de Entorno e Zona de Intervenção Baixa
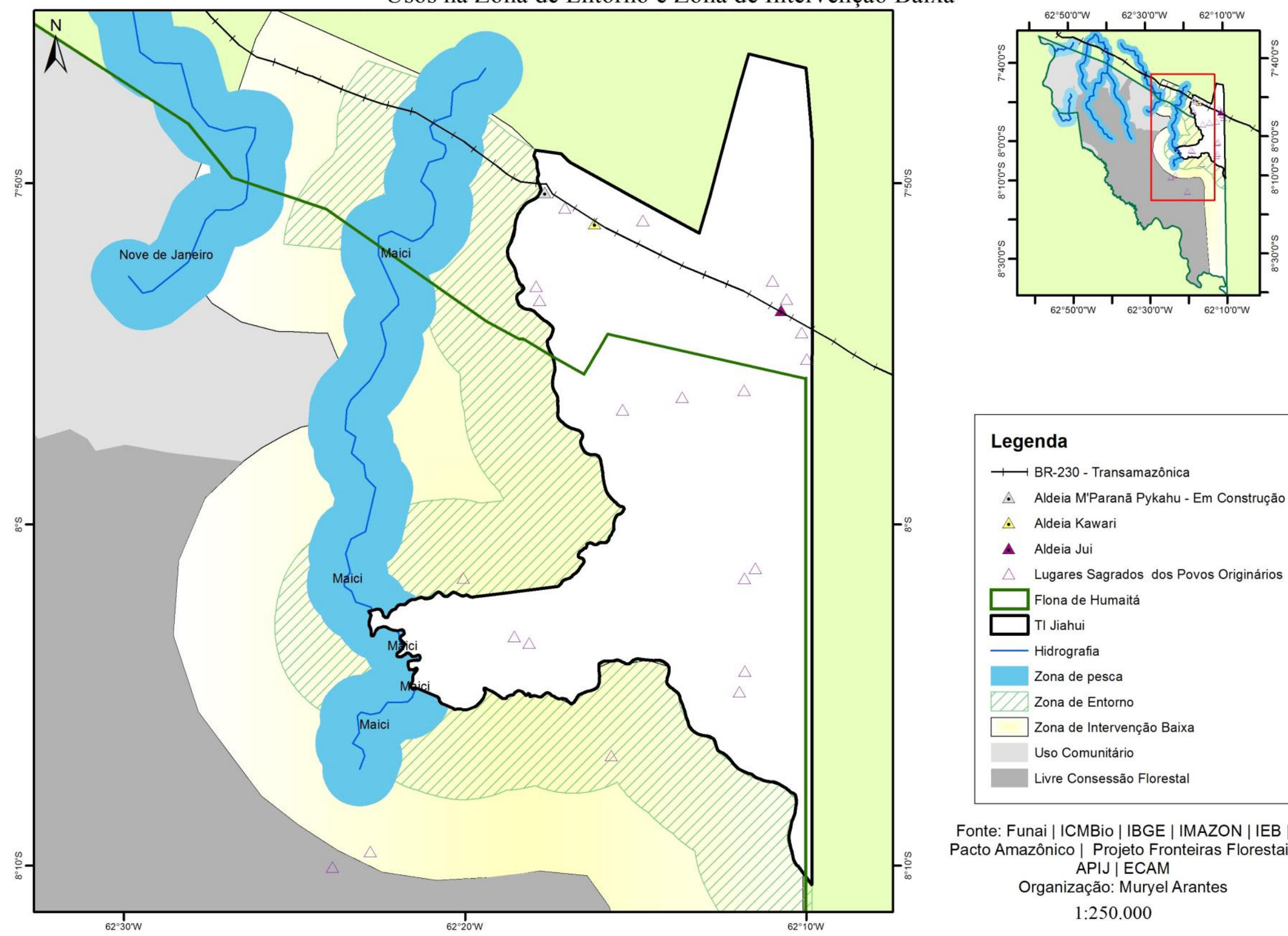

Figura 19 - Mapa de usos na área de fronteira entre TI e Flona

\section{Legenda}

$\longrightarrow$ BR-230 - Transamazônica

- Aldeia M'Paranã Pykahu - Em Construção

- Aldeia Kawari

A Aldeia Jui

$\Delta \quad$ Lugares Sagrados dos Povos Originários

$\square$ Flona de Humaitá

$\square$ TI Jiahui

- Hidrografia

Zona de pesca

Zona de Entorno

Zona de Intervenção Baixa

Uso Comunitário

Livre Consessão Florestal

Fonte: Funai | ICMBio | IBGE | IMAZON | IEB | Pacto Amazônico | Projeto Fronteiras Florestais APIJ | ECAM

Organização: Muryel Arantes

$1: 250.000$ 
As zonas diferenciadas no interior dos Territórios Protegidos mostram as atividades e os tipos de uso que os comunitários praticam. Na TI, o Etnomapeamento representa oito tipos de uso nos quais foi possível observar diversos usos e intensidade. Nas Zonas de Caça, Pesca e Produção, tem-se um tipo de uso direto e intenso em função do plantio das roças e da própria atividade de caça e pesca. Nas Zonas Primitiva e Sagrada o uso pode ser considerado direto, porém moderado, pois existe um cuidado especial recomendado aqueles que ali transitam pela preservação dos sítios sagrados e para resguardar os recursos naturais. Nas Zonas de Proteção Integral, Recuperação e Resgate, o uso é praticamente indireto, a perspectiva é de preservação e luta pelo reconhecimento de partes importantes do território. A mesma análise se aplica a Zona de Entorno.

Ao observar a dinâmica de apropriação territorial indígena infere-se que a organização social ali estabelecida apresenta uma lógica parecida com a ocidental. Ora, por meio do Etnozoneamento, os Jiahui determinaram áreas de uso direto e indireto, áreas de conservação e preservação. Tal qual o Estado realiza com as UCs. Talvez essa seja apenas uma leitura limitada pela impossibilidade de conhecer a organização social indígena tradicional, ou seja, em suas características próprias, anteriores à colonização. Mas diante das possibilidades de análise proporcionadas pelas fontes acessadas nesta pesquisa, conclui-se que se trata de uma micropolítica com sujeitos ativos no processo de gestão territorial e em constante diálogo com o Estado, via instituições governamentais.

O mapa de usos da Fona de Humaitá mostrou três zonas em toda sua extensão: Livre Concessão Florestal, Uso Comunitário e de Intervenção Baixa. Vale ressaltar que o Zoneamento oficial ainda não foi publicado, motivo pelo qual utilizou-se nesta pesquisa um estudo sobre os usos no interior da UC. O esperado neste caso é que o Zoneamento retrate tais usos e determine normas de uso conforme a dinâmica de apropriação já estabelecida na Flona. Praticamente toda a área é destinada à livre concessão florestal, área destinada ao manejo florestal sustentável, nos termos da Lei $\mathrm{N}^{\circ}$ 11.284. As regiões nas quais residem as comunidades foi denominada como de uso comunitário, e as proximidades da TI como Zona de Intervenção Baixa.

As atividades praticadas nessas áreas são predominantemente agricultura e extrativismo. $\mathrm{Na}$ porção do território próxima ao rio Madeira existem também garimpos. Além disso, uma área é destinada à proteção (Figura16) e denominada Estoque de Caça. Na porção centro-sul da Flona não foram mapeadas atividades, 
estradas ou sítios sagrados. Observou-se que diante dos usos praticados na flona, a apropriação dos comunitários e comunitárias é mais intenso ao norte da UC, com exceção das atividades de caça e pesca na Zona de Baixa Intervenção. Existe também a lógica de preservação e conservação em tais usos. O que mostra que a noção de preservação também existe, quando necessária, na perspectiva do uso.

Com essa primeira parte da análise tem-se o conhecimento básico sobre o objeto de estudo, o qual direcionou a observação das transformações territoriais. Até este ponto da pesquisa foram apresentados os aspectos de territorialidades vistos na trajetória de surgimento/reconhecimento dos territórios, nas políticas públicas de gestão e na dinâmica ali estabelecida em termos de uso. Aumentando a escala de análise sob tal objeto de estudo, as transformações territoriais foram vistas por meio de 13 indicadores socioambientais. Em outras palavras, estabelecidos os mecanismos de gestão fundamentados nas políticas públicas (escala nacional), e os usos que resultaram em zoneamentos específicos (escala local), iniciou-se uma análise multitemática.

Antes de discorrer sobre tais temas, cabe mencionar que, de um modo geral, as transformações territoriais mostraram que existe conservação socioambiental nos Territórios Protegidos. Os indicadores evidenciaram que o tipo de apropriação inerente ao modo de vida das comunidades locais - dentro das possibilidades impostas pelos dispositivos de gestão estatal - contribui para o sentido conservacionista nesses territórios. Isso foi constatado nos temas de monitoramento e governança; preservação e conservação; prevenção e mitigação de impactos negativos; dimensão sociocultural e práticas educativas. Assim, chega-se a conclusão de que no caso da Flona de Humaitá e da TI Jiahui, a sobreposição não comprometeu de maneira significante a conservação dos territórios.

Mesmo não apresentando um cenário de degradação socioambiental significativo nos Territórios Protegidos, o estudo deste caso possibilitou o apontamento de alguns aspectos dos dispositivos de gestão que se mostraram falhos. Olhar para tais mecanismos é importante para a reflexão sobre cenários futuros na Flona de Humaitá e TI Jiahui e também para a reflexão sobre o papel da gestão socioambiental nos demais Territórios Protegidos em sobreposição na Amazônia brasielira. Destacam-se, a seguir, alguns aspectos de tais dispositivos que foram observados nas transformações territoriais inerentes ao Território Usado.

As transformações territoriais relativas ao monitoramento e governança foram constatadas por meio de três indicadores, sendo o primeiro a presença de instrumentos 
de gestão tanto na Flona quanto na TI. Encontrou-se na TI a disponibilidade de vários instrumentos de gestão. Além daqueles previstos na PNGATI, os Jiahui elaboraram ainda o PGTA e outros projetos como o de Biomonitoramento. Por outro lado, a Flona ainda não conta com a principal ferramenta prevista no SNUC que é o PM. Apesar disso, os estudos que subsidiam o PM já estão em andamento e outros sobre os tipos de uso na Flona foram realizados por instituições do terceiro setor em parceria com as comunidades.

Os instrumentos de gestão dos territórios protegidos estão em fase de implementação, na TI, e de elaboração, na Flona. O que pode explicar o avanço da TI neste indicador é que existe espaço para autonomia dos indígenas na elaboração das ferramentas. Com base nisso, afirma-se que para avançar na elaboração de instrumentos de gestão, em UCs sustentáveis, é preciso aumentar o envolvimento e o empoderamento das populações locais, como no caso dos indígenas.

No segundo indicador do tema Monitoramento e Governança, o PPBIO, observou-se um considerável potencial para apoio à gestão da Flona e também para a TI, já que a Funai também é parceira do NR Humaitá. A contribuição do programa para a gestão dos Territórios Protegidos seria na área de monitoramento e difusão de conhecimentos sobre o bioma Amazônia, com envolvimento dos atores locais. A gestão atual da Flona ainda não consolidou a pareceria, mas existe uma perspectiva para fazêlo. Considera-se que a presença do programa no município de Humaitá e a intenção da gestão da Flona em fortalecer a parceria já é um aspecto positivo para a gestão. Da perspectiva da TI, notou-se que a comunidade ainda não enxerga tal potencial.

O terceiro, e último, indicador desse tema foi a gestão integrada. Os projetos e inciativas de gestão integrada se aplicam a duas situações: a princípio trata-se de estratégias de gestão de mosaicos de áreas protegidas, mas também se aplica a gestão dessas áreas no caso de sobreposição. Na primeira situação, observou-se que estar inserida no contexto de outras UCs foi importante para impulsionar a construção do PM, ainda que o licenciamento ambiental da rodovia tenha sido o principal motivador. A gestão integrada, voltada para a resolução da sobreposição não está encaminhada, ICMBio e Funai não criaram o GT para deliberar a respeito e não foram encontradas iniciativas para tal.

Em síntese, o monitoramento e a governança nos Territórios Protegidos estão fortalecidos nos aspectos de apropriação representados, principalmente, pela autonomia indígena na construção dos instrumentos de gestão e monitoramento. Nos mecanismos 
de gestão estatal existem ferramentas (como o PM e a Gestão Integrada) que somente serão bem aproveitadas a partir de uma maior participação dos atores locais, em especial dos moradores da Flona, que possuem melhores condições de contemplar e representar a perscepctiva socioambiental dos territórios no exercício da gestão e do monitoramento. Há ainda a necessidade de melhorar o acesso aos recursos de implementação das ferramentas disponíveis.

As transformações territoriais relativas ao tema preservação e conservação foram observadas por meio dos indicadores desmatamento e acordos de uso.Os resultados mostraram que as áreas desmatadas representam, em média, 1\% da área total dos Territórios Protegidos. Considerando que o uso nessas áreas é permitido, e necessário, o desmatamento constatado pelo Inpe é ínfimo, e condizente com o manejo florestal sustentável, ao qual se destinam estes territórios. Os focos de desmatamento se restrigem a região da Transamazônica. Portanto, a cobertura vegetal é conservada em relação a apropriação dos que ali vivem, especialmente nas zonas destinadas à proteção. Mas existe uma ameaça vinda do principal vetor de desmatamento da região, a BR-230.

Os acordos de uso não são efetivos nas áreas onde são necessários, ou seja, na Zona de Entorno e de Baixa Intervenção. O conflito instalado nessa área ocorre por não haver consenso entre os atores locais, sobre o uso. Tal situação pode comprometer a conservação socioambiental, considerando o direito dos comunitários, indígenas ou não, de acessarem os recursos da região e o próprio impacto que este conflito pode trazer ao rio Maici, e aos recursos hídricos de um modo geral.

A preservação e a conservação nos Territórios Protegidos foram vistas para além dos indicadores elencados para tal temática. Desde os instrumentos de gestão foi possível constatar que as duas noções fazem parte da dinâmica local. Tratando-se especificamente da esfera ambiental. A cobertura vegetal, que é um dos primeiros elementos da paisagem a ser degradado, encontra-se preservada. Mas é importante direcionar ações no sentido de resolver os conflitos de uso na Zona de Entorno e mitigar o impacto da rodovia.

A análise do tema anterior possibilitou a inferência dos principais enfoques necessários para prevenir e mitigar. Antes mesmo do estudo dos indicadores elencados para observação do tema Prevenção e mitigação de impactos negativos, foi possível identificar ações importantes para este tema: prevenir o desmatamento ilegal e mitigar os impactos da rodovia Transamazônica. Assim, somou-se a tal inferência os 
indicadores Incremento de Desmatamento, Espécies-Chave e Número de Espécies em Extinção.

Ao considerar os resultados dos indicadores de preservação e conservação - que foram bons do ponto de vista da conservação socioambiental - a prevenção tornou-se o principal foco de análise e reflexão sobre prevenção e mitigação. Como era esperado, os índices de incremento de desmatamento não foram representativos, ora, com o tipo de desmatamento encontrado, não seria possível existir taxas de aumento de tal fênomeno.

Os dados de Espécies-Chave demonstrados pelo Biomonitoramento da TI, reforçaram a importância da prevenção. Notou-se que as principais espécies que sustentam a tadição da caça, a fonte proteica e o equilíbrio ecossistêmico na TI ainda são representativas no território Jiahui. O mesmo pode-se afirmar das espécies em extinção. Os Territórios Protegidos abrigam cerca de 10 espécies em extinção, sendo duas na Flona e oito na TI. Estes dados podem aumentar quando for publicado o PM da Flona, que realizou um estudo mais detalhado sobre o tema.

Diante do exposto, afirma-se que ações preventivas são de extrema relevância para salvaguardar a sociobiodiversidade existente nos Territórios Protegidos. Os indicadores utilizados para investigar esta temática, ainda que pouco representativos em termos de quantidade, forneceram argumentos empíricos para justificar a importância da prevenção, em destaque, mas também da mitigação.

A dimensão sociocultural foi contemplada nos indicadores AAI mulheres, projetos e atividades dos moradores da Flona e programas do PGTA Jiahui. As transformações territoriais observadas por tais indicadores reafirmaram a relevância da dinâmica de apropriação territorial local - antes mencionada - e principalmente, destacou o papel dos atores locais no exercício de suas territorialidades. As relações de poder construídas no processo de gestão na escala local envolvem mulheres; pequenos produtores/extrativistas e indígenas, evidentemente em diálogo com os dispositivos de gestão estatal.

A participação das mulheres indígenas nesse tipo de atividade, que também faz parte das estratégias de gestão local, ainda é incipiente. Mas as duas formações realizadas na TI Jiahui representam o potencial que existe para dar continuidade ao envolvimento das mulheres. Isso de acordo com os costumes e possibilidades da comunidade.

Os tipos de atividades praticadas pelos moradores da Flona fazem parte do que se espera da realização de um manejo sustentável em UCs. No entanto, os projetos que 
dariam subsídios, técnicos, financeiros e de pessoal, às práticas produtivas, ainda são insuficientes. De acordo com as fontes da pesquisa, apenas uma comunidade participa de um projeto da Conab. Pelos relatos da participação das assossiações junto ao conselho consultivo, pode-se inferir que os entraves nas documentações necessárias à comprovação das atividades prejudicam a participação em projetos de incentivo a produção.

Neste indicador, nota-se que as associações fortalecem a representatividade dos moradores junto ao Conselho da Flona. Apesar disso, a ausência do PM compromete o processo de regularização e comprovação das atividades, ficando apenas a cargo dos comunitários a organização e comprovação de suas atividades. O ideal seria contar com um instrumento de gestão, na perspectiva de gestão estatal, aliada ao papel das associações, na perspectiva da gestão local.

Os programas do PGTA Jiahui demonstraram a perspectiva de gestão dos indígenas, bem como suas prioridades. Os cinco programas, elaborados para os próximos 40 anos, revelaram que a perspectiva de gestão dos Jiahui está em sintonia com as diretrizes da PNGATI. Mas os meios de acessar recursos de implementação não ficaram evidentes durante a pesquisa. Assim como ocorre com os moradores da Flona, fica a cargo das lideranças Jiahui realizarem articulações políticas junto à instituições governamentais e do terceiro setor, no intuito de conseguir recuros para as ações planejadas.

Além do entrave para implementação do PGTA, uma outra questão, sobre a qual a explicação ficou além das possibilidades da pesquisa, deve ser mencionada. Refiro-me a forma de planejar e monitorar as ações de cada área prioritária - seja saúde, educação, proteção, etc. - que se assemelha muito aos procedimentos de gestão ocidental. Sobre isso fica a reflexão: em que medida tal documento facilita o diálogo com instituições governamentais responsáveis e possíveis parceiros? Seria amplo, na comunidade, o entendimento dessa forma de planejar e gestar os recursos do território? Essas questões podem ser investigadas em outra pesquisa.

Por fim, observou-se as práticas educativas. Mais uma vez foi possível perceber a relação deste tema com aqueles analisados anteriormente. Se antes constatou-se que a prevenção exige mais atenção, maior número de ações, para se manter o atual cenário relativamente conservado, as práticas educativas estão no mesmo nível de importância. Isso se considerarmos que a Educação Ambiental é uma prática efetiva para garantir cenários futuros de conservação. 
Nesse sentido, observaram-se dois indicadores: as capacitações e as atividades de Educação Ambiental. Em termos de capacitações, os indígenas apresentaram boa articulação em cursos relacionados à saúde e ao ambiente. Na Flona, as capacitações foram realizadas predominantemente nas áreas de produção e governança. Para o futuro, os Jiahui planejam investir mais nas áreas em que já se capacitaram e inovar nas áreas de tecnologia, produção e proteção territorial. Para os moradores da Flona seria interessante capacitações para as assossiações já estabelecidas, para que possam ter subsídios para lidar com os entraves encontrados na regularização de suas atividades produtivas.

Se os indicadores socioambientais de transformações territoriais evidenciaram que existe um nível aceitável de conservação nos territórios protegidos, e que a prioridade neste caso seria a prevenção, afirma-se que as capacitações e atividades de educação ambiental devem ser incorporadas aos mecanismos de gestão. A recomendação neste caso, é além dos temas já indicados pelos atores locais, sejam inseridos temas relacionados às políticas públicas e gestão de conflitos. Isso porque a dimensão política do conflito encontrado na zona de entorno pode, no futuro próximo, afetar o atual cenário.

Para tal recomendação, apenas uma ressalva deve ser feita, considerando Territórios Protegidos com populações tradicionais: é preciso reconhecer que os princípios da relação sociedade e natureza que pautam a Educação Ambiental já fazem parte dos modos de vida tradicionais. Fato constatado empiricamente pela compilação das atividades praticadas nos territórios estudados e pelos impactos ambientais que estas causaram. Em tal contexto, a educação ambiental deve se destinar aos atuais problemas socioambientais que também afetam as TIs e deve ser compatível com as tradições locais e consequentemente com as práticas de ensino aprendizagem com as quais os indígenas estão habituados ou dispostos a implementar (se forem práticas inovadoras).

Em termos práticos, os instrumentos de gestão, previstos no SNUC e na PNGATI, são registros dos usos praticados nos territórios. A partir de tais registros da dinâmica territorial, é que se traçam as estratégias de planejamento para cenários futuros. Com tal afirmação pretende-se destacar a característica não impositiva dos instrumentos (em termos práticos), ou seja, eles retratam a dinâmica atual e só a partir disso subsidiam projeções de usos futuros.

Com isso conclui-se que os instrumentos de gestão se consolidam de maneira integrada com a dinâmica local. Relembrando que as diretrizes das políticas também são 
complementares, tornou-se evidente que os meios de se planejar e implementar tais instrumentos precisam ser avaliados. Assim, infere-se que, nos casos de sobreposição, os instrumentos de gestão devem ser elaborados e implementados de forma conjunta, ou seja, de maneira integrada politicamente, culturalmente e tecnicamente. Acredita-se que assim estes possam apresentar conteúdos semelhantes e complementares, conforme a dinâmica territorial.

Considerar tal nível de integração é importante para a conservação dos Territórios Protegidos. Isso diante do fato de que a dimensão ambiental ainda está conservada mas o cenário político, as territorialidades e as relações de poder podem projetar cenários futuros de degradação. Defende-se aqui a necessidade do fortalecimento político, nas relações de poder entre atores locais e governo, e da integração dos instrumentos de gestão, necessária do ponto de vista técnico.

Os indicadores que contemplaram a dimensão ambiental - Desmatamento, Incremento de Desmatamento, Espécies-Chave e Número de Espécies em Extinção fundamentam a afirmação de que existe um bom nível de conservação nos Territórios Protegidos. A situação destes indicadores está diretamente relacionada aos diversos usos inerentes à dinâmica de apropriação dos atores locais. Dessa maneira, as transformações territoriais, observadas nesta perspectiva, mostraram que existe correspondência entre as diretrizes das políticas públicas e a dinâmica socioambiental local.

Já a dimensão política, analisada com auxílio dos demais indicadores, apresentou falhas nos dispositivos de gestão. A problemática encontrada neste ponto consiste na relação entre tais dispositivos e os usos. Os conflitos ocorrem na escala local, entre indígenas e moradores da Flona, e entre os atores locais - indígenas e não indígenas - e as instituições governamentais que representam o poder público responsável pelos mecanismos de gestão. Além disso, como os principais instrumentos de gestão são independentes, mesmo estando os objetos a serem gestados em sobreposição, perde-se um potencial importante na busca pela resolução de tais conflitos.

Em síntese, a análise dos indicadores evidenciou que nos territórios existe equidade em relação às transformações territoriais observadas nos grupos Preservação/Conservação e Prevenção/Mitigação de impactos negativos. Como pode ser observado na tabela 11, Flona e TI apresentam o mesmo nível de efetividade nos referidos temas, o que representa um bom indicador de conservação socioambiental.

Já nos demais grupos observados o nível de efetividade das políticas públicas caiu e consequentemente a conservação socioambiental. Além disso, a TI apresentou 
resultados melhores do que aqueles encontrados na UC. No grupo de Monitoramento e Governança essa discrepância se deve aos instrumentos de gestão. O fato da Flona ainda não ter publicado o plano de manejo influenciou nesse resultado. Nos demais, a representatividade dos moradores da Flona e participação na gestão da UC é que pode ser responsável pelos resultados inferiores (tabela 11).

Tabela 11 - Análise dos Indicadores

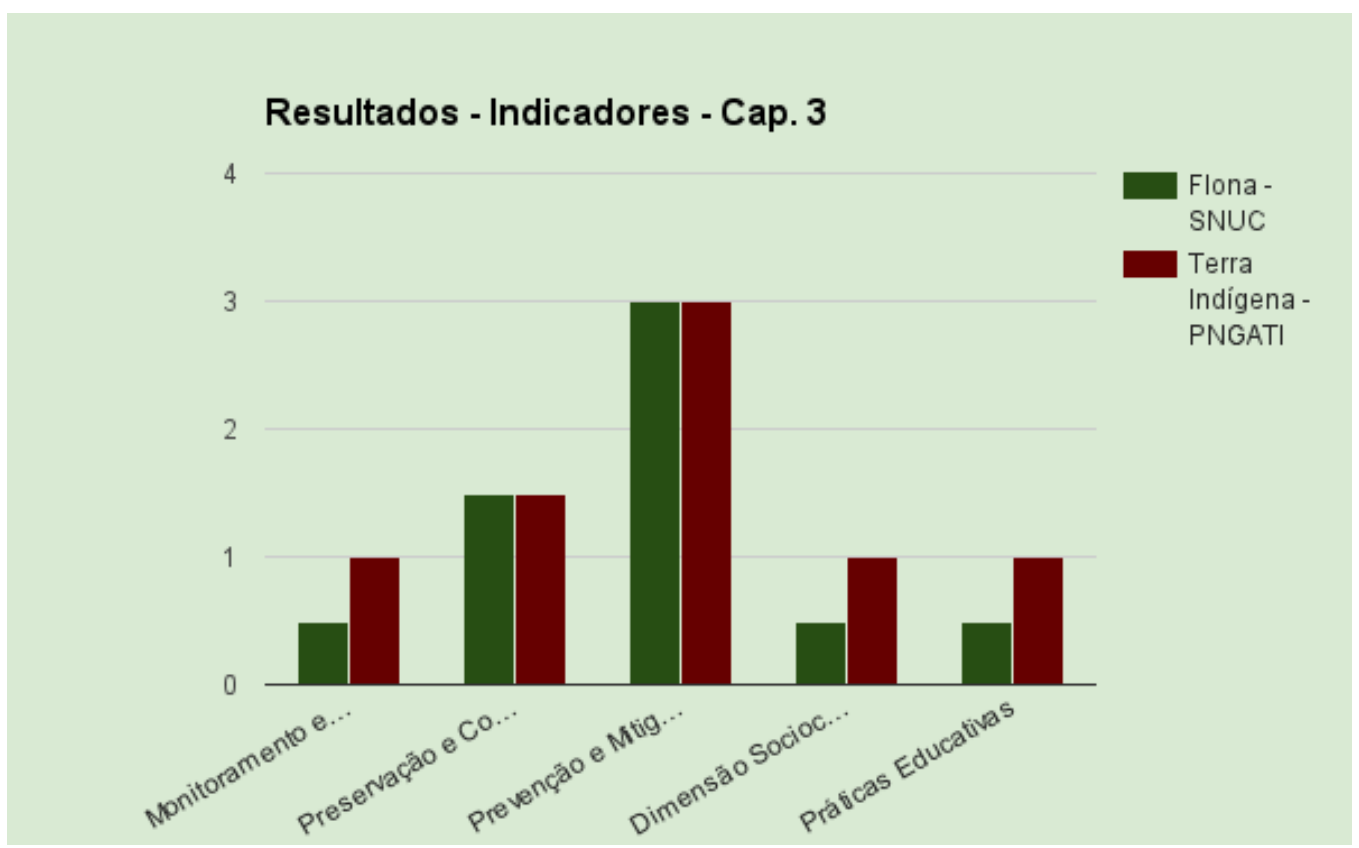

As relações de poder inerentes ao processo de apropriação desses territórios se mostraram o ponto mais problemático no contexto dos mecanismos de gestão. Sabe-se que a estrutura de políticas públicas setoriais não possibilita a construção de instrumentos de gestão integrados e com mais participação dos atores locais. Isso seria imprescindível para se alcançar a resolução dos conflitos e possibilitar a sustentação do atual cenário e a conquista de cenários futuros melhores.

Como a dimensão política e ambiental estão inter-relacionadas na perspectiva socioambiental dos Territórios Protegidos, infere-se que a atual conjuntura política nos territórios e nas relações de poder entre comunitários e poder público se insere como fator de degradação e pode comprometer os cenários futuros. A atual estrutura das políticas públicas setoriais implica na multiplicidade de órgãos responsáveis pelas mesmas questões (legalidade, conservação, etc.) e em instrumentos de gestão que apesar de serem planejados sob as mesmas diretrizes não se complementam de fato. Mas 
poderiam se complementar por meio da adoção de uma perspectiva espacial no fazer das políticas públicas ambientais e indigenistas. 


\section{CONSIDERAÇÕES FINAIS}

Esta pesquisa resulta de uma reflexão sobre Territórios Protegidos em sobreposição na Amazônia brasileira. Os resultados alcançados neste trabalho representam a busca de subsídios teóricos, empíricos e metodológicos para contribuir com a análise e debate sobre o papel da gestão na conservação socioambiental em tais territórios.

As questões levantadas durante este processo estiveram localizadas entre os dispositivos de gestão estatal e a dinâmica socioambiental dos territórios. Buscou-se evidenciar - com base nos termos do Território Usado - as características dos usos decorrentes das relações de apropriação e propriedade do Estado e das comunidades locais com os territórios. Assim, chegou-se ao questionamento sobre o nexo entre modelo de gestão e conservação socioambiental.

Em relação às estruturas de gestão, previstas nas políticas ambiental e indigenista, obteve-se um entendimento focado na trajetória de criação e nas diretrizes e objetivos do SNUC e da PNGATI, respaldadas pelos artigos 231 e 225 da Constituição Federal. $\mathrm{Na}$ perspectiva dos territórios, realizou-se uma leitura direcionada por tais políticas. A dinâmica territorial foi observada com base em dados locais e também com auxílio de alguns dados secundários de instituições estatais.

Desse modo, houve um avanço no entendimento da relação entre dispositivos de gestão, usos e conservação socioambiental. Tal aspecto relacional evidenciado fundamenta uma análise integrada e propositiva. Sendo assim, afirma-se que há, nesta pesquisa, subsídios para entendimento, problematização e proposição acerca do caráter relacional entre tais temas.

É válido mencionar um possível direcionamento para se aprofundar os estudos sobre tal relação. Como a metodologia proposta se restringiu aos objetivos e diretrizes das políticas públicas federais (SNUC e PNGATI), tornou-se evidente a necessidade de uma análise dos programas e dos departamentos relacionados às políticas ambiental e indigenista. Como por exemplo, o Progama Áreas Protegidas da Amazônia (ARPA); Projeto de Gestão Ambiental e Territorial Indígena (GATI); Órgãos Estaduais de Meio Ambiente (OEMAs) e Secretaria Especial de Saúde Indígena (Sesai). A análise desses programas e projetos pode contribuir na compreensão das relações entre a gestão e as

dinâmicas territoriais das Áreas Protegidas. É possível que tal aprofundamento ocorra também na perspectiva dos territórios por meio da validação dos dados apresentados 
nos indicadores e do monitoramento. Dessa maneira, seria possível avançar no entendimento da estrutura de gestão e acompanhar as constantes mudanças próprias da dinâmica territorial.

A hipótese de que os mecanismos de gestão das políticas públicas seriam fatores de degradação socioambiental para os Territórios Protegidos, no caso de sobreposição foi confirmada parcialmente. Tal possibilidade foi observada em três campos da gestão: objetivos e diretrizes do SNUC e da PNGATI; instrumentos de gestão e meios de elaboração e impelementação.

Não foi possível confirmar ou refutar a hipótese levantada considerando a gestão de maneira generalizada, pois os mecanismos de gestão apresentam um nível de complexidade que extrapola a metodologia aqui proposta. Mas, foi possível realizar a análise a partir dos referidos campos - objetivos e diretrizes do SNUC e da PNGATI; instrumentos de gestão e meios de elaboração e implementação. Dessa maneira, inferese que no contexto dos mecanismos de gestão, as diretrizes, objetivos e instrumentos não são fatores de degradação. No entanto, os meios de elaboração das políticas, por setores diferenciados, fazem com que sejam restritas as possibilidades de integração e complementação no exercício da gestão de territórios sobrepostos.

Por fim, tal análise, baseada no estudo de caso da Flona de Humaita e da TI Jiahui, pode subsidiar estudos sobre a gestão dos demais territórios em sobreposição na Amazônia brasileira. Não foi possível analisar os três campos da gestão para os territórios protegidos em sobreposição em toda Amazônia, por limitações do tipo de pequisa escolhido. Foi possível apresentar uma metodologia para realizar tal análise. Considerando o recorte escolhido para este trabalho (UCs de uso Sustentável e TIs) seriam necessários estudos de, aproximadamente, 10 casos para concluir a análise das sobreposições em toda Amazônia brasileira.

Diante da proposta metodológica enuciada, o objetivo geral da pesquisa foi alcançado. Foram levantadas as referências empíricas e teóricas do estudo de caso, o que proporcionou uma análise da atual gestão de territórios protegidos em sobreposição na Amazônia brasileira.

Dos quatro objetivos gerais, dois foram alcançados de maneira integral, um parcialmente e um não foi viável. A princípio, o estudo classificatório das políticas e a seleção de indicadores a partir de tal classificação foi realizado conforme o previsto. Já o direcionamento da análise dos dados especificamente nas zonas definidas nos instrumentos não foi possível, primeiro porque o PM da Flona ainda não foi publicado e 
segundo pelo fato de que alguns indicadores, como desmatamento por exemplo, são publicados considerando toda extensão dos territórios. Para uma análise específica das zonas, seria necessária uma outra metodologia com previsão de atividades de validação de dados em campo.

O último objetivo específico, a análise da relação entre as transformações territoriais e as diretrizes das políticas públicas, foi alcançado, mas não com base apenas nos instrumentos de gestão. No desenvolver da pesquisa estes se transformaram em indicadores integrantes de um contexto dos demais. Ainda que considerados como referência, pelo teor de seus conteúdos, somaram-se a um conjunto. Em outras palavras, a referida análise foi feita com auxílio de 16 indicadores, e não apenas pelos instrumentos de gestão como previsto.

O marco conceitual estabelecido para a realização deste trabalho foi insuficiente. No âmbito da Geografia isso pode ser entendido de duas formas. Por um lado reforça a importância da transdiciplinaridade, do diálogo entre as disciplinas na produção do saber científico. Por outro, revela a ausência de um referencial teórico que se aplique aos Territórios Protegidos. Esta lacuna pode ser resultado da histórica dicotomia geográfica que por muito tempo impediu a integração e a complementação inerente a abordagem socioambiental.

Ainda que com base no trabalho de autores clássicos ${ }^{41}$ da Geografia, é possível visualizar uma mudança no sentido de uma ciência integrada, com complementação entre os estudos dos sistemas naturais e humanos realizados com auxílio das técnicas cartográficas e de geoprocessamento. Essa ideia faz parte das diretrizes da Geografia Socioambiental, linha de pesquisa que também compôs o referencial teórico e que precisa ser reforçada no âmbito das pesquisas.

A metodologia proposta nesta pesquisa permitiu o direcionamento do trabalho. A estruturação dos passos metodológicos guiados por algumas referências de método, atribuiram clareza ao processo de pesquisa. Apenas sua complexidade limitou o aprofundamento dissertativo em apenas um elemento. Tal escolha esteve clara e justifica-se pelo cumprimento do projeto de pesquisa e dos resultados atingidos.

O fazer dessa pesquisa proporcionou uma reflexão para além daquela enunciada na metodologia. Observou-se, por meio de marcos legais e de políticas públicas delimitados, que o processo de territorialização da TIs foi marcado pela marginalização

\footnotetext{
${ }^{41}$ Clássicos no sentido de amplo conhecimento e não da Geografia Clássica do séc. XIX.
} 
da população indígena no tempo-espaço. E, além disso, há também a marginalização dessas populações e de seus territórios nos atuais espaços de discussão ambiental. Nos estudos bibliográficos e documentais, nas participações em eventos propostos para discutir a problemática ambiental e nos diálogos com instituições governamentais nas esferas federal e municipal vivenciei momentos nos quais a questão indígena foi marginalizada. Neste contexto, é como se mapas temáticos fossem apresentados sem a representação das TIs. Apenas sabemos que estes territórios existem e possuem alto potencial de conservação socioambiental. 


\section{Referências}

ALVES, F.S. \& OLIVEIRA, F.S. Prática pedagógica de Educação Ambiental no ensino de Geografia: necessidade de transição de paradigmas. In: Pesquisa em Educação Ambiental, vol. 3, n. 2 - pp. 9-24, 2008. Universidade de São Paulo.

BÊZ, M; FIGUEIREIDO, L. C. Algumas reflexões acerca da geografia socioambiental e comunidade. In: Geosul, v.26, n. 52, p. 57-76, jul/dez 2011. Florianópolis - SC.

BECKER,B.Amazônia: geopolítica na virada do III milênio. Rio de Janeiro: Garamond, 2009.

Novas Territorialidades na Amazônia: desafio às políticas públicas. In:Bol. Mus. Para. Emílio Goeldi. Cienc. Hum., Belém, v. 5, n. 1, p. 17-23, jan.- abr. 2010

BRASIL. Constituição (1988). Constituição da República Federativa do Brasil. Brasília, DF: Câmara dos Deputados, $35^{\circ}$ ed.2012.

Lei $\mathbf{n}^{\mathbf{0}}$ 9.985, de 18 de Julho de 2000. Regulamenta o artigo 225, § $1^{\circ}$, incisos I, II, III e VII da Constituição Federal, institui o Sistema Nacional de Unidades de Conservação da Natureza e dá outras providências. Ministério do Meio Ambiente, Brasília. Disponível em: <http://www.mma.gov.br /port/sbf/dap/doc/snuc.pdf>. Acesso em 07 de novembro de 2013 às 16h25min.

CAMPOS, N.; KRAHL, M. F. L.. Territorialidade: Elo de ligação entre espaço rural e o espaço urbano-algumas reflexões teórico-conceituais. In: Marília Steinberger. (Org.). Território, Ambiente e Políticas Espaciais. 01ed.Brasília: Paralelo 15, 2006.

CORREIA, C. S. Etnozoneamento, Etnomapeamento e Diagnóstico Etnoambiental: representações cartográficas e gestão territorial em terras indígenas no estado do Acre. Tese de Doutorado Programa de pós-graduação em Antropologia Social do Departamento de Antropologia da Universidade de Brasília. 2007.

ECAM, Equipe de Conservação da Amazônia. Plano de Proteção Territorial da Terra Indígena Jiahui. Humaitá-AM.2013.

FLORIANO, P.E. Políticas de Gestão Ambiental. Universidade Federal de Santa Maria/Departamento de Ciências Florestais. $3^{\mathrm{a}}$ ed. 2007.

FONSECA, A., Souza Jr., C., \& Veríssimo, A. 2014. Boletim do desmatamento da Amazônia Legal (outubro de 2014) SAD (p. 10). Belém: Imazon 
FUNAG, Fundação Alexandre de Gusamão. Estocolmo, Rio, Joanesburgo - O Brasil nas três conferências ambientais das nações unidas. Ministério das Relações Exteriores, 2006.

GIL, Antonio C. Métodos e Técnicas de Pesquisa Social. $5^{\text {a }}$ ed. São Paulo: Atlas, 1999.

GONÇALVES, A. O conceito de governança. In: XIV Congresso Nacional do Conpedi - Conselho Nacional de Pesquisa e Pós-Graduação em Direito Fortaleza, 2005.

GONÇALVES, C.W.P Da Geografia às geo-grafias: um mundo em busca de novas territorialidades.

HAESBAERT, R. Dos múltiplos territórios á multiTerritorialidade. Porto Alegre, Setembro de 2004a.

HAESBAERT, R. O mito da desterritorialização. Ed. Bertrand, Rio de Janeiro/RJ, 2004b. 396p. ISBN 978-85-286-1061-1.

HAESBAERT, R. Territórios Alternativos. São Paulo: Contexto, 2006.

ISA, Instituto Socioambiental. Terras Indígenas e Unidades de Conservação da natureza: o desafio das sobreposições. Org. Fany Ricardo - São Paulo: 2004. ISBN 85-85994-31-2

LEITÃO, S. Superposição de leis e de vontades - por que não se resolve o conflito entre Terras Indígenas e Unidades de Conservação? In: RICARDO, F.(Org.) Terras Indígenas \& Unidades de Conservação da Natureza: 0 desafio das sobreposições. São Paulo: Instituto Socioambiental, 2004.

LIMA, D.\& POZZOBON, J. Amazônia Socioambiental. Sustentabilidade Ecológica e Diversidade Social. In: Estudos Avançados 19 (54), 2005.

LOPES, D.B. O direito dos índios no Brasil: a trajetória dos grupos indígenas nas constituições do país. In: Espaço Ameríndio, Porto Alegre, v. 8, n. 1, p. 83-108, jan./jun. 2014.

MACHADO, M. C. Mapeamento Cultural e Gestão Territorial de Terras Indígenas: o uso dos Etnomapas. Dissertação de Mestrado em Geografia - Gestão Ambiental e Territorial. Universidade de Brasília - UnB, 2014.

MARGULIS, S. O desempenho do governo brasileiro e Banco Mundial com relação a questão ambiental em projetos co-financiados pelo banco. IPEA, 1990.

MENDONÇA, Francisco de Assis. Geografia Socioambiental. In:Terra Livre, n. 16, p. 113-132, $1^{\circ}$ sem. 2001. 
MORAES, A. C. R. Geografia, interdisciplinaridade e metodologia. GEOUSP Espaço e Tempo (Online), São Paulo, v. 18, n. 1, p. 9-39, 2014.

Annablume, 2005.

Meio Ambiente e Ciências Humanas. $4^{\text {a }}$ Edição / São Paulo:

OLIVEIRA, S. F. Unidades de Conservação (UCs): contexto histórico e a realidade do estado de Goiás. In: ALMEIDA, M.G. (Org.) Abordagens geográficas de Goiás: o natural e o social na contemporaneidade. Universidade Federal de Goiás, Instituto de Estudos Socioambientais. Goiânia, 2002.

PAGNOCCHESCHI, B. \& BERNARDO, M. Política Ambiental. In: Marília Steinberger. (Org.). Território, Ambiente e Políticas Espaciais. 01ed.Brasília: Paralelo 15, 2006.

RIBEIRO, B.; VERÍSSIMO, A. \& PEREIRA, K. O avanço do desmatamento sobre as Territórios protegidos em Rondônia. O Estado da Amazônia6. Belém: Imazon. 2005.

RICHARDSON, R.J. Pesquisa social: métodos e técnicas. 3. Ed. São Paulo: Atlas, 1999.

SANTILI, J. Povos Indígenas, quilombolas e populações tradicionais: a construção de novas categorias jurídicas. In: RICARDO, F.(Org.) Terras Indígenas \& Unidades de Conservação da Natureza: o desafio das sobreposições. São Paulo: Instituto Socioambiental, 2004.

SANTOS, M. \&SILVEIRAM M.L. A questão: o uso do território. In: O Brasil: território e sociedade no início do século XXI.10a ed. Rio de Janeiro: Record, 2008.

SANTOS, M. Metamorfoses do Espaço Habitado: fundamentos teóricos e metodológicos da geografia. São Paulo: Editora da Universidade de São Paulo. 2008.

O dinheiro e o território. In: Território, territórios: ensaios sobre o ordenamento territorial. Lamparina Editora. $3^{\mathrm{a}}$ ed. Programa de PósGraduação em Geografia da Universidade Federal Fluminense (PPGEO/UFF), 1999 (a).

O território e o saber local: algumas categorias de análise. In: Cadernos IPPUR, Rio de Janeiro, Ano XIII, No 2, 1999, p. 15-26 (b)

A questão do meio ambiente: desafios para a construção de uma perspectiva transdisciplinar. Anales de Geografia de la Universidad Complutense no15, 695-705. 1995.

SANTOS, M; SOUZA, M.A; SILVEIRA, M.L. Território, globalização e fragmentação. ed. Hucitec - Anpur. São Paulo, 1994 
SAQUET, Marcos Aurélio. Abordagens e concepções de território. São Paulo: Expressão popular, 2007.

SERPA, Angelo. Políticas Públicas e o Papel da Geografia. Revista ANPEGE. v.7, n.1, número especial, p.34-47, 2011.

SOUZA, M.A. Meio ambiente e desenvolvimento sustentável. As metáforas do capitalismo. Cronos, Natal-RN, n², 2009. 


\section{Anexos}

A) Autorização da Apij para o acesso aos dados da TI Jiahui

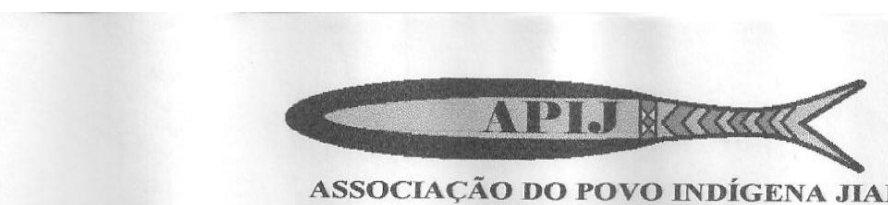

CNPJ: $09.145 .332 / 0001-39$

Carta n० 021/APIJ/2015

Humaitá-AM, 05 de Maio de 2015

A

Senhora

Muryel Moraes Arantes

Estudante Pós-Graduação em Geografia-UNB

Brasília-DF

Copia: Copia ao Colaborador para o Povo Jiahui/CR-Madeira/FUNAI

Assunto: Autorização

A Associação do Povo Indígena Jiahui (APIJ), autoriza a pesquisadora Murye/ Moraes Arantes, estudante da Pós-Graduação em Geografia - Gestão Ambiental e Territorial - no Departamento de Geografia (GEA) da Universidade de Brasília (UnB), matrícula 140099778, a utilizar os dados do Etnomapeamento, Etnozoneamento e Plano de Gestão da Terra Indígena Jiahui para embasamento de sua pesquisa de mestrado intitulada "Gestão Socioambiental de Territórios Protegidos em Sobreposição na Amazônia Brasileira". Autorizamos o uso dos referidos estudos para finalidades acadêmicas, incluindo publicaçōes resguardadas a autoria do povo Jiahui e parceiros na produção dos dados e informações.

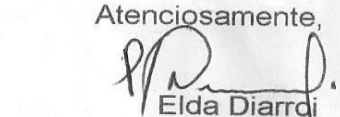

Coordenadora Geral Administrativa APIJ

BR 230 KM 01 Bairro São Cristóvåo n ${ }^{\circ} 1957$ - CEP: 69.800-000 - Humaitá - Amazona

Telefone-fax: 97-8124-2369/98108-3918/99185-9518

E-mail: apijiahui@yahoo.com.br/nilceliodiarrui@gmail.com 
B) Autorização ICMBio para a pesquisa com os dados da Flona

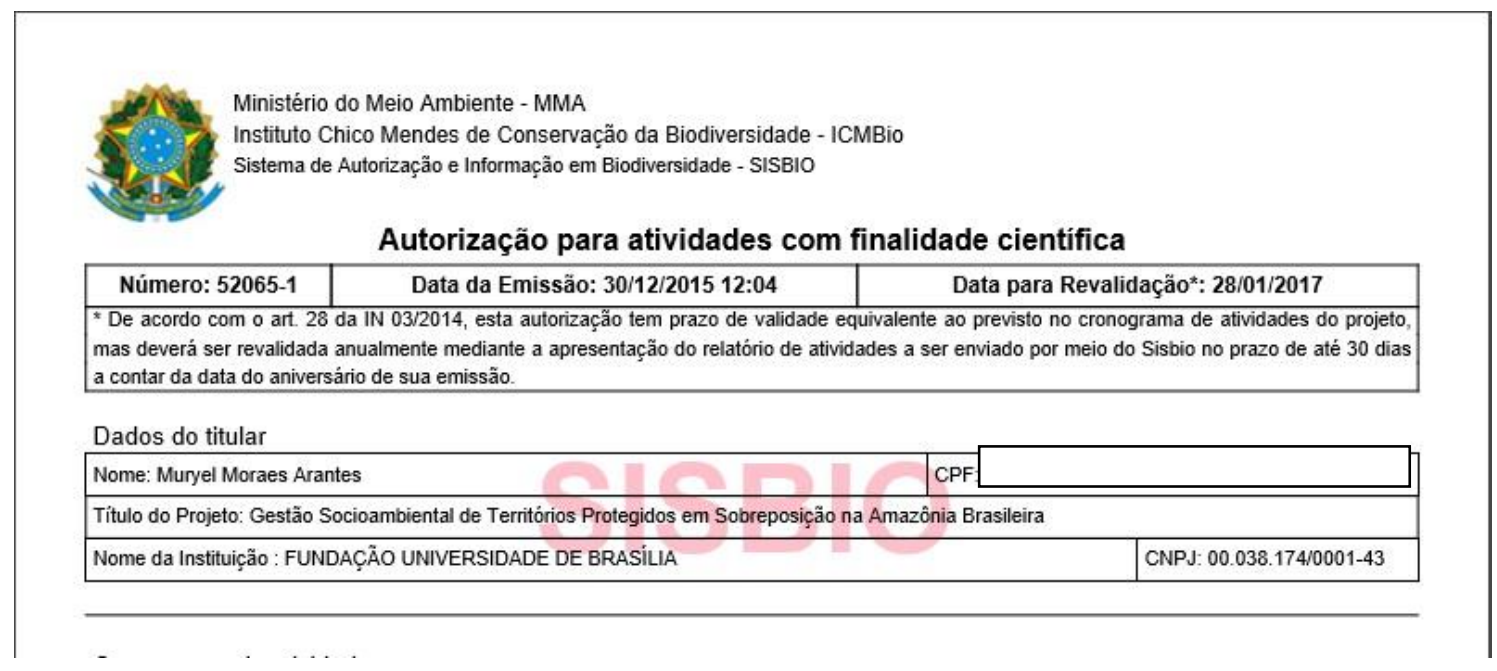

C) Entrevistas Semi-estruturadas realizadas com a equipe gestora da Flona de Humaitá.

1 - Bom dia Sra. Leila, estou realizando uma pesquisa de mestrado sobre a questão das sobreposições de áreas protegidas, meu referencial empírico é o caso da Flona de Humaita e do território Jiahui. Gostaria de acessar o zoneamento e/ou estudos de meio físico da Flona, você saberia me informar um meio de acessar estes estudos, caso eles existam?

2 - Conforme explicado no pedido de autorização de pesquisa $\mathrm{n}^{\circ} 52065$ submetido ao SISBIO, preciso acessar os estudos que irão subsidiar o plano de manejo da FLONA. Vocês me informaram que este trabalho estava em andamento, então gostaria de saber se avançaram nesta demanda e se existe algum dado que eu possa acessar para minha pesquisa. Estou trabalhando com indicadores socioambientais em área de sobreposição entre UC e Terra Indígena, e por isso seria de extrema importância para a imparcialidade de minha pesquisa contar com dados da FLONA como parte desses indicadores. O ideal seria acessar o zoneamento, o plano de manejo completo, já que na perspectiva da TI já trabalho no etnozoneamento e plano de gestão. Mas considerando que esses instrumentos da FLONA ainda estão em construção, qualquer dado que eu puder acessar já é válido para representar essa UC no contexto dos indicadores que estou estudando.

3-Prezad@s, 
Envio abaixo a lista dos indicadores que estou observando, estes representam as as informações que preciso saber da Flona, o ideal seria observar esses dados conforme as zonas, se tiverem um esboço delas seria ótimo.

4 - Prezad@s, boa tarde! Gostaria de saber se vocês tem a lista de espécies em extinção na Flona de Humaitá. Mais uma vez, obrigada! 